INTER NATIONAL MONETARY FUND

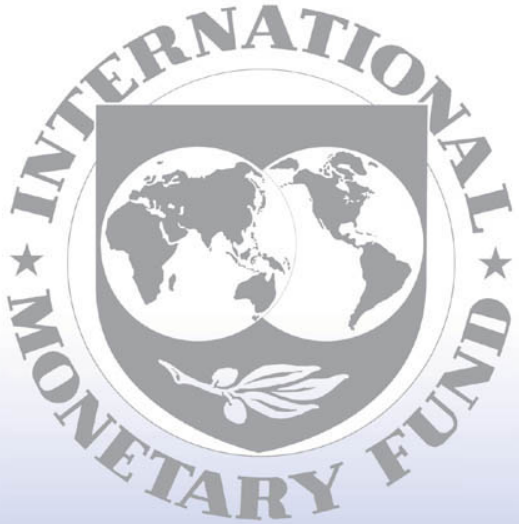

Staff

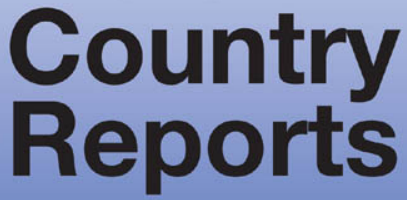




\section{Indonesia: Selected Issues}

This Selected Issues paper for Indonesia was prepared by a staff team of the International Monetary Fund as background documentation for the periodic consultation with the member country. It is based on the information available at the time it was completed on June 29, 2005. The views expressed in this document are those of the staff team and do not necessarily reflect the views of the government of Indonesia or the Executive Board of the IMF.

The policy of publication of staff reports and other documents by the IMF allows for the deletion of market-sensitive information.

To assist the IMF in evaluating the publication policy, reader comments are invited and may be sent by e-mail to publicationpolicy@imf.org.

Copies of this report are available to the public from

International Monetary Fund • Publication Services

700 19th Street, N.W. • Washington, D.C. 20431

Telephone: (202) 6237430 • Telefax: (202) 6237201

E-mail: publications@imf.org • Internet: http://www.imf.org

Price: $\$ 15.00$ a copy

\section{International Monetary Fund Washington, D.C.}


This page intentionally left blank 


\section{INTERNATIONAL MONETARY FUND}

\section{INDONESIA}

\section{Selected Issues}

Prepared by Nita Thacker, Yougesh Khatri, Geremia Palomba, Ashok Bhundia (all APD), Amine Mati (FAD), Matthew Jones (PDR), and Leslie Eng Teo (MFD)

Approved by the Asia and Pacific Department

June 29, 2005

Contents

I. Overview: Economic Policies for Growth and Employment Creation..........................

II. An Empirical Analysis of Long-Term Growth in Indonesia ........................................ $\underline{6}$

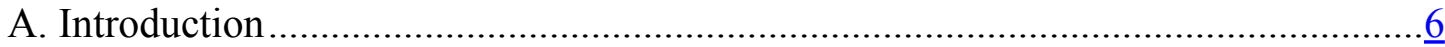

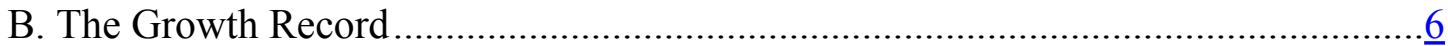

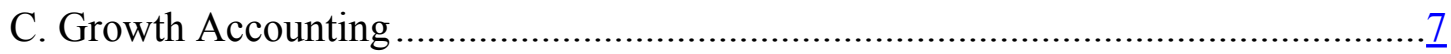

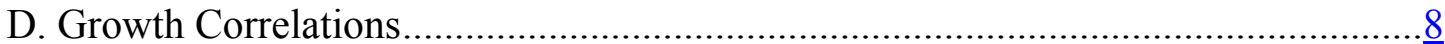

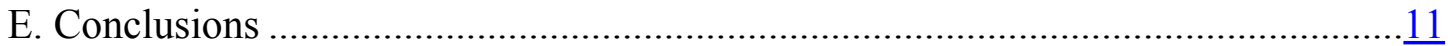

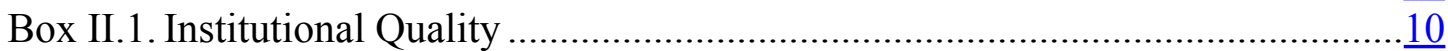

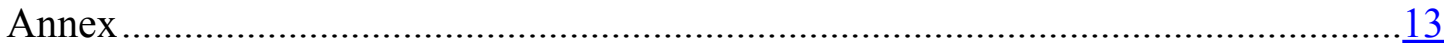

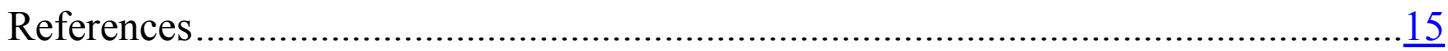

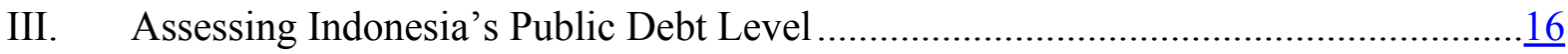

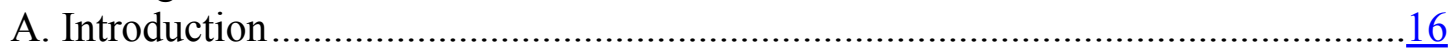

B. The Characteristics of Indonesia's Public Debt ...................................................17

C. Debt Threshold and Vulnerability: an Application of the Early Warning System.$\underline{18}$

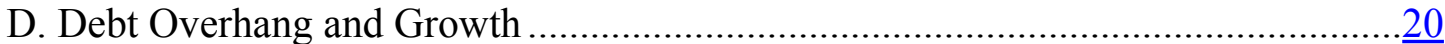

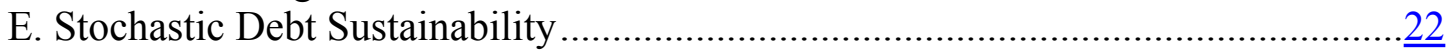

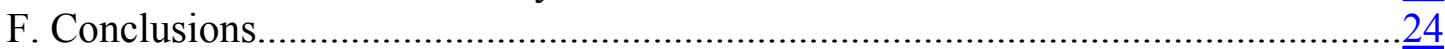

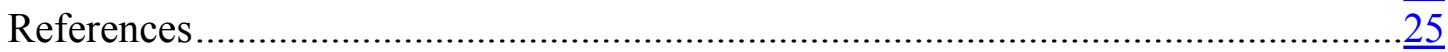

IV. The Banking Sector: Recent Developments and Future Issues ..................................27

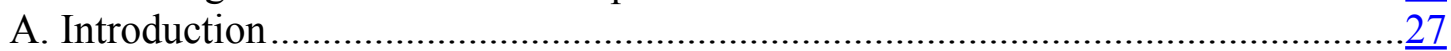

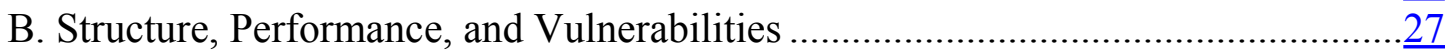

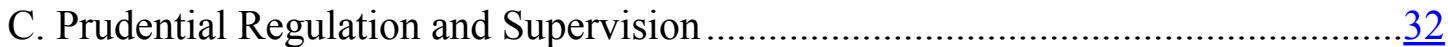

D. Credit Growth: Determinants and Risks .........................................................

E. Conclusions: Outlook and Policy Issues ........................................................

Box III.1 Corporate Governance and Risk Management in Banks ……....................

Box III.2 The Banking Architecture Plan .............................................................39 
Box III.3 Prudential Regulation and Supervision ................................................ $\underline{40}$

Box III.4 Financial Safety Net and Deposit Insurance Scheme............................... $\frac{41}{42}$

Box III.5 Empirical Analysis of Bank Credit Growth .......................................... 42

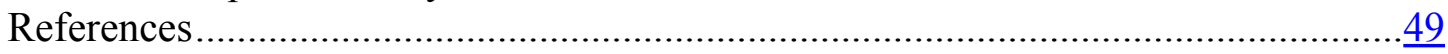

V. Indonesia's External Competitiveness: An Update ............................................50

A. Real Effective Exchange Rate Indicators..................................................

B. Export performance............................................................................... $\frac{51}{54}$

C. Econometric Estimates of the Equilibrium Real Exchange Rate.........................54

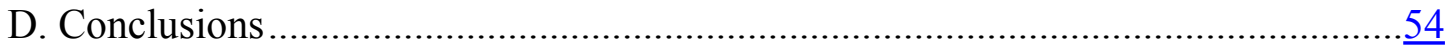

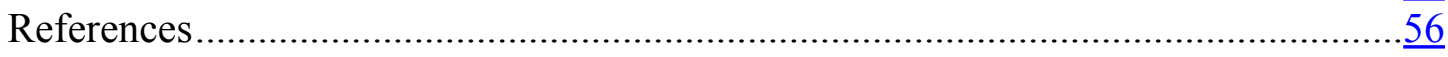

VI. The Oil and Gas Sector: Prospects and Policy Issues ......................................... $\underline{58}$

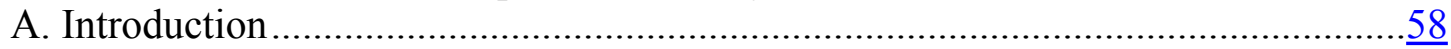

B. Recent Developments and Policies ............................................................. $\frac{58}{61}$

C. Indonesia's Fiscal Regime-An International Perspective................................. $\frac{61}{62}$

D. Economic Policies to Attract Investment..........................................................62

E. Conclusions ................................................................................

Box VI.1 Regulatory Developments in the Oil and Gas Sector .............................. $\frac{65}{66}$

Box VI.2 Contribution of the Oil and Gas Sector, Alternative Scenarios ................... $\frac{66}{68}$

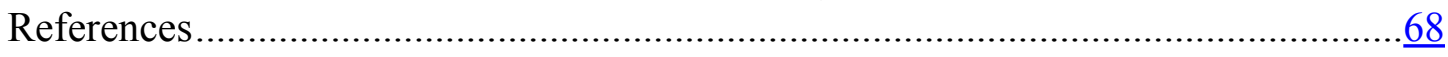

VII. Labor Market Policies and Job Creation..........................................................69

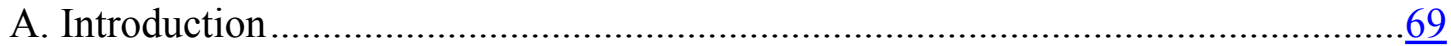

B. The Indonesia Labor Market—Some Stylized Facts ….................................

C. Elasticity of Employment......................................................................... $\frac{70}{71}$

D. Explaining Unemployment ................................................................... $\frac{71}{72}$

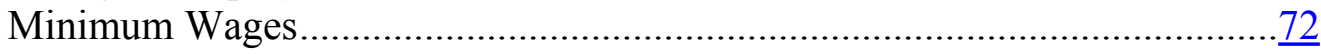

Severance Pay .................................................................................. $\frac{73}{74}$

Outsourcing and fixed term contracts ................................................. $\frac{74}{75}$

E. Policies for Employment Creation .................................................... $\frac{75}{80}$

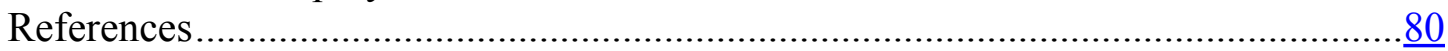




\section{Overview: Economic Policies for Growth ANd Employment Creation ${ }^{1}$}

1. Indonesia has made significant progress in establishing macroeconomic stability and reducing vulnerabilities since the crisis, and growth has been picking up. Economic growth reached 5.1 percent in 2004, the highest annual rate since the crisis, increasingly bolstered by investment and exports besides private consumption. Meanwhile, inflation and interest rates have declined from their post-crisis peaks. Following the major cleanup of the banking sector after the crisis, banks' performance has improved as net interest margins and profitability have increased. Public and external debt ratios have declined and international reserves have, until recently, risen, reducing domestic and external vulnerabilities.

2. Despite this favorable record, the recovery in Indonesia has been slower than in other crisis-hit countries in Asia, and employment creation has fallen short. Indonesia stands out as having experienced a slower recovery in investment and exports than other countries hit by the Asian crisis. Moreover, the increase in economic activity has not been accompanied by job creation, although there are some recent encouraging signs, and registered unemployment has increased every year since the crisis.

3. Recognizing the challenge, the new government has adopted a sound mediumterm strategy focused on boosting economic growth. The strategy is built on a continuation of macro-economic stability and reforms in the financial sector, coupled with a reinforced effort to improve the investment climate.

4. This paper takes an in-depth look at selected aspects of the government's growth strategy. The first chapter sets the stage by examining Indonesia's growth experience in a longer-term perspective, seeking to draw lessons for the future. Each of the following chapters deal with a specific topic that is central to the government's growth strategy: the role of public debt in affecting vulnerabilities and growth; the state of the banking system and key issues going forward in ensuring that the system can effectively mobilize and channel saving for investment, and not be the fulcrum of crisis; Indonesia's external competitiveness, which will be key in sustaining the recovery in exports; the potential role of the petroleum sector, and in particular the policies needed for Indonesia to benefit from its considerable petroleum resources; and, finally, how the labor market functions and what could be done to translate higher GDP growth into employment creation. In summary:

- $\quad$ The paper starts out with An Empirical Analysis of Long-Term Growth in

Indonesia. The chapter examines Indonesia's long-run growth performance in an effort to understand the factors behind the favorable record in the decades before the Asian crisis. Using a growth accounting framework, the analysis suggests that productivity growth was the major driving force in the 1960s, while capital accumulation has played a complementary role in later decades. A cross-country

\footnotetext{
${ }^{1}$ Prepared by Nita Thacker (APD).
} 
analysis of long-term growth underscores the importance of the quality of institutions and fiscal prudence for Indonesia.

- The next chapter assesses Indonesia's Public Debt Level, starting out from a recognition that the level of public debt, while greatly reduced since the immediate aftermath of the crisis, remains relatively high for an emerging market country like Indonesia. This is the case both from the point of view of vulnerabilities and crowding out. Using different approaches to assessing the appropriate upper debt level, the analysis concludes that a reduction in public debt towards the 35-42 percent of GDP range or below would be considered an appropriate medium-term target for Indonesia.

- The following chapter reviews Recent Developments and Future Issues in the Banking Sector. The chapter concludes that, the recent strong credit growth notwithstanding, there is considerable scope for the sector to expand. Indeed, the ratio of bank credit to the private sector and the loan-to-deposit ratio are both relatively low in a regional comparison. By the same token, going forward, a strengthening of the banks' capacity to manage risks and further improvements in prudential regulations and supervision, as planned by the authorities, will be key to ensuring a sound banking sector that can play a successful role in supporting investment and growth.

- The paper then turns to a discussion of Indonesia's External Competitiveness. While the evidence is mixed, the chapter concludes that, on balance, external competitiveness is not an immediate concern. Real effective exchange rate indicators and estimates of the equilibrium real exchange rate suggest that Indonesia's competitive position has improved since mid-2003 and that it is adequate. On the other hand, an analysis of the post-crisis export performance underscores the need for caution in assessing competitiveness. Indeed, the real effective exchange rate indicators may not capture the full story, as the weak non-oil export growth in recent years suggests that structural shortcomings have been hampering export performance.

- $\quad$ The following chapter reviews the potential contribution of the Oil and Gas Sector to Indonesia's growth prospects. Following an overview of the sector's role in the economy, the chapter discusses Indonesia's regulatory and fiscal arrangements for the petroleum sector in a regional context, the government's energy reform strategy, and policies for attracting investment. The sector's overall role in the economy is likely to decline over time, and the chapter underscores the need to diversify exports and improve competitiveness, optimize energy use, and develop the base for non-oil and gas revenues. All of these are important elements of the government's medium-term economic strategy.

- Dealing with Indonesia's pervasive unemployment problem is among the most important objectives of the government, and this is the focus of the last chapter, Labor Market Policies and Job Creation. In seeking to explain the lack of job 
creation in the post-crisis period, the chapter focuses on real wage growth, productivity developments, and the role of labor market legislation. The chapter also compares Indonesia's regulatory regime for the labor market with those of other countries in the region. It concludes that recent sharp increases in real minimum wages, high severance payments, and restrictions on outsourcing have contributed to increased unemployment and growth of the informal sector. The chapter puts forward a range of policies that could help translate growth into jobs. 


\section{AN EMPIRICAL ANALYSIS OF LONG-TERM GROWTH IN INDONESIA ${ }^{1}$}

\section{A. Introduction}

\section{This chapter presents an empirical assessment of Indonesia's growth} performance since the $1960 \mathrm{~s}$, in a cross-country perspective. The chapter starts with an analysis of long-run growth in a growth accounting framework, assessing the extent to which growth has been driven by factor accumulation versus gains in total factor productivity (TFP). It then reviews cross-country variations in growth performance, seeking to assess whether and in what ways Indonesia's experience differs from that of other countries. Taken together, the growth accounting and regression results support the Indonesian government's emphasis on enhancing the quality of institutions, including by addressing corruption, and maintaining a prudent fiscal policy.

\section{B. The Growth Record}

\section{In an international comparison,} Indonesia has made impressive gains in living standards since the 1960s. Income per capita increased more than fourfold from the mid1960s to the mid-1990s. While this period was not one of consistently high growth, over time Indonesia came to be counted among the "Asian tigers." Like other fast-growing Asian economies, Indonesia experienced higher average growth in per capita incomes than the rest of the world (Table).

\section{Hand in hand with this solid economic growth, the Indonesian economy also} underwent significant structural change. The share of manufacturing in GDP increased substantially over time, while the share of agriculture registered a large decline reaching 18 percent by 1993 .

\begin{tabular}{|lc|}
\hline \multicolumn{2}{|c|}{$\begin{array}{c}\text { Average Per Capita Real GDP Growth, 1960-2000 1/ } \\
\text { (Annual percent changes) }\end{array}$} \\
\hline Developing countries & 1.37 \\
Latin America & 1.37 \\
Argentina & 1.00 \\
Brazil & 2.77 \\
Mexico & 1.97 \\
East Asia & 3.45 \\
Indonesia & 3.52 \\
Korea & 5.99 \\
Malaysia & 3.98 \\
Thailand & 4.91 \\
Philippines & 1.41 \\
South Asia & 2.11 \\
Middle East & 2.74 \\
Sub-Saharan Africa & 0.57 \\
Industrial countries & 2.69 \\
Germany & 2.03 \\
Japan & 4.23 \\
USA & 2.49 \\
All countries & 1.80 \\
\hline Sources: Bosworth and Collins (2003); and Fund staff estimate & \\
Note: Growth rates are weighted by average GDP (PPP) \\
during 1960-64. \\
1/ At purchasing power parity. & \\
\hline
\end{tabular}

\footnotetext{
${ }^{1}$ Prepared by Ashok Bhundia (APD).
} 
4. Periods of high growth in Indonesia have been relatively long lasting. Hausmann et al. (2004) find that Indonesia has had two "growth accelerations" during the period under review-in 1967 and 1987-the same as Korea and Malaysia. ${ }^{2}$ In the case of Indonesia, annual real GDP growth increased from 3 percent in 1967 to 11 percent in 1968 , and averaged more

\begin{tabular}{|c|c|c|c|c|c|c|}
\hline \multicolumn{7}{|c|}{ Growth and Structural Change } \\
\hline & \multicolumn{3}{|c|}{ Sector share of GDP (percent) } & \multicolumn{3}{|c|}{ Real growth (percent per annum) } \\
\hline & 1971 & 1980 & 1993 & $71-80$ & $80-85$ & $85-90$ \\
\hline Agriculture and mining & 33 & 24 & 18 & 3.7 & 2.4 & 3.2 \\
\hline Industry & 37 & 46 & 47 & 10.5 & 3.4 & 7.0 \\
\hline Services & 30 & 30 & 34 & 7.9 & 5.6 & 6.5 \\
\hline GDP non-oil & 73 & 72 & 80 & 7.8 & 5.7 & 7.0 \\
\hline GDP & 100 & 100 & 100 & 7.9 & 3.9 & 6.3 \\
\hline
\end{tabular}
than 8 percent from 1968 to 1975 . Similar average growth rates were achieved during the second acceleration phase, from 1987 to 1996.

\section{Growth Accounting}

5. Growth accounting can be used to assess the extent to which observed output growth has been driven by factor accumulation versus TFP gains. The convention is to assume a (Cobb-Douglas) constant returns to scale aggregate production function, so that:

$$
Y=A K^{\alpha} L^{(1-\alpha)}
$$

where $\mathrm{Y}$ is aggregate output, $\mathrm{A}$ is total factor productivity, $\mathrm{K}$ is the physical capital stock, $\mathrm{L}$ is units of labor, and $\alpha$ is the elasticity of output with respect to the physical capital stock. Expressing the equation in terms of units of labor (denoted in small case letters), and taking logs and their difference give:

$$
\Delta \log \mathrm{y}=\Delta \log \mathrm{A}+\alpha \Delta \log \mathrm{k}
$$

where growth in output per unit of labor is the sum of growth in total factor productivity (growth in A) and growth in capital-labor ratio weighted by $\alpha$. Estimates of TFP are sensitive to the value $\alpha$, which is the elasticity of output with respect to the capital-labor ratio. Sarel (1997) finds that for a group of six Asian economies,

\begin{tabular}{|c|c|c|c|}
\hline \multicolumn{4}{|c|}{ Growth Accounting, Selected Asian Economies, 1961-1996 1/ } \\
\hline \multicolumn{4}{|c|}{ Average annual percentage change } \\
\hline & GDP per worker & TFP & Physical capital 1/ \\
\hline Indonesia & 3.9 & 1.9 & 5.8 \\
\hline Korea & 5.1 & 2.1 & 8.6 \\
\hline Malaysia & 4.0 & 1.8 & 7.0 \\
\hline Philippines & 1.0 & 0.1 & 2.5 \\
\hline \multirow[t]{2}{*}{ Thailand } & 5.1 & 2.2 & 8.1 \\
\hline & \multicolumn{3}{|c|}{ Average annual contributions to growth (percentage points) } \\
\hline Indonesia & 3.9 & 1.8 & 1.9 \\
\hline Korea & 5.1 & 2.1 & 2.9 \\
\hline Malaysia & 4.0 & 1.7 & 2.3 \\
\hline Philippines & 1.0 & 0.2 & 0.9 \\
\hline Thailand & 5.1 & 2.2 & 2.7 \\
\hline Source: Fun & $\begin{array}{l}\text { alculations. } \\
\text { er worker. }\end{array}$ & & \\
\hline
\end{tabular}
estimated $\alpha$ is in the narrow range of

${ }^{2}$ Hausman et al. (2004) define a growth acceleration as a period when growth increases by at least 2 percentage points, and is a minimum of $3 \frac{1}{2}$ percent per annum in each year of the acceleration period, which is a period of at least 8 years. 
$0.28-0.35$. For Indonesia he finds $\alpha=0.35$, the value used in the growth accounting exercise in this chapter.

\section{Compared with its peer} countries, in the long run TFP growth has contributed relatively more to Indonesia's real GDP growth than capital accumulation. Looking at different time periods, however, it appears that while Indonesia's growth was primarily productivity driven in the 1960s, capital accumulation played a complementary role in subsequent decades (Table). ${ }^{3}$ Capital accumulation can further spur GDP growth if the new capital embodies technological advances that improve the efficiency of resource utilization and thus TFP. This is what happened during growth accelerations in Indonesia and the comparator Asian countries. Korea and Thailand, for example, countries that achieved a higher long-run growth performance in 1960-96 in part because of productivity gains associated with high rates of investment.

\section{Growth Correlations}

\section{This section uses data from a cross-section of countries to identify factors}

correlated with long-run growth performance. A number of different specifications were used, and a set of dummy variables included in the regressions to assess whether parameters which were associated with growth for the whole sample have a different effect in the case of Indonesia. The regression equation was estimated using ordinary least squares by pooling a panel of observations for each variable across a sample of countries. ${ }^{4}$ For each country $i$, the basic regression is specified as follows:

${ }^{3}$ Since TFP is calculated as the residual from a constant returns to scale production function, it will, by construction, exhibit comovement with GDP over the business cycle because movements in the capital stock and labor force exhibit less volatility than output. However, this comovement should "wash out" over a longer period.

${ }^{4}$ The panel dataset is constructed as 5-year averages for each variable. However, in the case of institutional quality, the variable is constant. 


$$
\Delta \mathrm{y}_{\mathrm{i}}=\alpha+\beta \mathrm{y}_{0 \mathrm{i}}+\delta \mathrm{E}_{\mathrm{i}}+\gamma[\text { institutions }]_{\mathrm{i}}+\lambda[\text { macroeconomic variables }]_{\mathrm{i}}
$$

$\Delta y$ is the average growth rate of GDP over the period 1960-2000, $\mathrm{y}_{0}$ is initial income, $\mathrm{E}$ is level of education, [institutions] are indicators of institutional quality, and [macroeconomic variables] are both policy related variables, such as the size of government (defined as share of government consumption in GDP), and other variables, such as a measure of terms of trade volatility. Institutional quality is measured by an index taken from the International Country Risk Guide, summarized in Box II.1.

Equations 1 to 3 (Table) point to a significant correlation between growth and the following variables: institutional quality, education level; external volatility; and government spending. Equations 4 and 5 report the results when multiplicative Indonesia-specific dummy variables are included for institutional quality. Taken together, the results suggest that: ${ }^{5}$

- Growth is negatively correlated with the initial level of income, consistent with the conditional convergence hypothesis that poorer economies should see some "catch up" in productivity and income levels with respect to richer economies.

- $\quad$ Growth is positively correlated with institutional quality. The multiplicative Indonesia dummy suggests that improvements in institutional quality are relatively more important in the case of Indonesia, although the dummy variable is significant only at the 10 percent level.

- $\quad$ Growth is negatively correlated with government size. Possible detrimental effects include crowding out of private sector activity through credit markets and taxation. The negative and significant Indonesia dummy suggests that this detrimental effect, while still important, may have been smaller for Indonesia than in other countries in the sample.

- Growth is negatively correlated with terms of trade volatility, while it is positively correlated with the level of schooling.

- Institutional quality, government spending, and terms of trade also affect growth through TFP (Table, Equation 6).

\footnotetext{
${ }^{5}$ The regression results should be seen as descriptive rather than unveiling causal relationships, since OLS estimates do not correct for potential endogeneity and reverse causality. The annex provides a listing of the variables, their definitions, and sources.
} 


\section{Box II.1. Institutional Quality}

The measure of institutional quality used in the econometric analysis was constructed by Knack and Keefer (1995), and is based on information from surveys conducted by the International Country Risk Guide, a provider of international investor risk services. The index is made up of five elements, each of which measures a particular aspect of the security of property and contract rights: the quality of bureaucracy; corruption in government; rule of law; expropriation risk; and repudiation of contracts by government. Survey respondents were asked to mark each of the five elements for a particular country on a scale.

\section{Quality of bureaucracy}

A higher score indicates "autonomy from political pressure" and "strength and expertise to govern without drastic changes in policy or interruptions in government services."

\section{Corruption in government}

In this category, the score indicates the extent to which "high government officials are likely to demand special payments" and to which extent "illegal payments are generally expected throughout lower levels of government."

$\underline{\text { Rule of law }}$

This variable "reflects the degree to which the citizens of a country are willing to accept the established institutions to make and implement laws and adjudicate disputes." Higher scores indicate "sound political institutions, a strong court system, and provisions for an orderly succession of power."

\section{Expropriation risk}

This is an assessment of risk of "outright confiscation" or "forced nationalization."

\section{$\underline{\text { Repudiation of contracts }}$}

Indicates the "risk of a modification in a contract taking the form of a repudiation, postponement, or scaling down," due to "budget cutbacks, indigenization pressure, a change in government, or a change in government economic and social priorities." 


\begin{tabular}{|c|c|c|c|c|c|c|}
\hline \multicolumn{7}{|c|}{ Cross-Country Growth Regressions } \\
\hline \multirow{2}{*}{\begin{tabular}{|l|} 
Dependent variable \\
Equation \\
\end{tabular}} & \multicolumn{5}{|c|}{$\begin{array}{l}\text { GDP } \\
\text { growth }\end{array}$} & \multirow{2}{*}{$\begin{array}{c}\begin{array}{c}\text { TFP } \\
\text { growth }\end{array} \\
6 \\
\end{array}$} \\
\hline & 1 & 2 & 3 & 4 & 5 & \\
\hline $\log$ of initial GDP & $\begin{array}{c}0.12 \\
(0.046)^{* *}\end{array}$ & $\begin{array}{c}0.12 \\
(0.041)^{* *}\end{array}$ & $\begin{array}{c}-0.623 \\
(0.204)^{* * *}\end{array}$ & $\begin{array}{c}-0.573 \\
(0.204)^{* * *}\end{array}$ & $\begin{array}{c}-0.568 \\
(0.204)^{* * *}\end{array}$ & $\begin{array}{l}-0.139 \\
(0.188)\end{array}$ \\
\hline Average schooling & $\begin{array}{c}0.02 \\
(0.005)^{* * *}\end{array}$ & $\begin{array}{c}0.007 \\
(0.004)^{* * *}\end{array}$ & $\begin{array}{c}0.011 \\
(0.007)^{*}\end{array}$ & $\begin{array}{c}0.011 \\
(0.007)^{*}\end{array}$ & $\begin{array}{c}0.011 \\
(0.007)^{*}\end{array}$ & $\begin{array}{c}0.001 \\
(0.006)\end{array}$ \\
\hline External volatility & $\begin{array}{c}-0.68 \\
(0.106)^{* * *}\end{array}$ & $\begin{array}{c}-0.19 \\
(0.131)\end{array}$ & $\begin{array}{c}-0.049 \\
(0.018)^{* * *}\end{array}$ & $\begin{array}{c}-0.049 \\
(0.018)^{* * *}\end{array}$ & $\begin{array}{c}-0.049 \\
(0.018)^{* * *}\end{array}$ & $\begin{array}{c}-0.061 \\
(0.016)^{* * *}\end{array}$ \\
\hline \multicolumn{7}{|l|}{ External volatility dummy } \\
\hline Institutional quality & & $\begin{array}{c}2.27 \\
(0.396)^{* * *}\end{array}$ & $\begin{array}{c}5.219 \\
(0.780)^{* * *}\end{array}$ & $\begin{array}{c}5.16 \\
(0.778)^{* * *}\end{array}$ & $\begin{array}{c}5.16 \\
(0.778)^{* * *}\end{array}$ & $\begin{array}{c}3.266 \\
(0.704)^{* * *}\end{array}$ \\
\hline Institutional dummy & & & & $\begin{array}{c}4.757 \\
(2.587)^{*}\end{array}$ & & \\
\hline Government size & & & $\begin{array}{c}-0.147 \\
(0.026)^{* * *}\end{array}$ & $\begin{array}{c}-0.144 \\
(0.025)^{* * *}\end{array}$ & $\begin{array}{c}-0.145 \\
(0.025)^{* * *}\end{array}$ & $\begin{array}{c}-0.106 \\
(0.022)^{* * *}\end{array}$ \\
\hline Government size dummy & & & & & $\begin{array}{c}0.213 \\
(0.106)^{* *}\end{array}$ & \\
\hline constant & $\begin{array}{c}10.1 \\
(0.542)^{* *}\end{array}$ & $\begin{array}{c}8.09 \\
(0.626)^{* * *}\end{array}$ & $\begin{array}{c}0.093 \\
(0.825)\end{array}$ & $\begin{array}{c}0.167 \\
(0.823)\end{array}$ & $\begin{array}{c}0.185 \\
(0.823)\end{array}$ & $\begin{array}{l}-0.445 \\
(0.745)\end{array}$ \\
\hline Observations & 74 & 74 & 457 & 457 & 457 & 449 \\
\hline Adjusted $R^{2}$ & 0.63 & 0.62 & 0.18 & 0.18 & 0.18 & 0.15 \\
\hline $\begin{aligned} & \text { Source: Fund staft calcula } \\
& \text { Notes: } \text { Numbers in parent } \\
& \text { Significance levels } \\
& \text { Ordinary Least Squ }\end{aligned}$ & $\begin{array}{l}\text { are standa } \\
* * 1 \text { percen } \\
\text { egression }\end{array}$ & $\begin{array}{l}\text { ors. } \\
\text { percent; } * 11 \\
\text { oled data. }\end{array}$ & cent. & & & \\
\hline
\end{tabular}

\section{E. Conclusions}

8. The two approaches for studying growth in Indonesia presented in this chapter provide complementary insights into what has mattered for growth. The growth accounting exercise suggests that GDP growth in the 1960s was closely associated with increases in TFP growth, while capital accumulation has contributed more importantly in subsequent decades. The regression results provide some evidence of a number of factors that have been correlated with growth across a sample of countries over the last four decades. These correlations point to several policy implications for a growth strategy for Indonesia:

The government's emphasis on improving institutional quality, such as tackling corruption, should yield growth benefits. The government's agenda to improve governance has the potential to make a significant contribution to growth. The gain from improvements in institutional quality appear to be even larger in Indonesia than in other countries in the sample.

- Maintaining prudent fiscal policy would help support long-term growth. While the impact of the level of government spending on long-term growth may be less in Indonesia than in the overall sample, the results indicate that it is nevertheless important. It should be kept in mind, however, that issues regarding the composition 
of government spending (not reflected in the empirical analysis), rather than the overall level, may also have been important for Indonesia's growth record.

- Expanded education provision would support long-term growth. Increased education underpins growth by enhancing labor productivity and the capacity to absorb new technologies which, in turn, would boost TFP. This finding suggests that the Indonesian government's emphasis on improving education provision would help support growth. 


\section{List of Countries}

\begin{tabular}{|c|c|c|}
\hline$\underline{\text { Sub-Saharan Africa (33) }}$ & $\underline{\text { Latin America (22) }}$ & Europe (16) \\
\hline Benin & Argentina & Austria \\
\hline Botswana & Bolivia & Belgium \\
\hline Burkina Faso & Brazil & Cyprus \\
\hline Burundi & Chile & Denmark \\
\hline Cameroon & Colombia & Finland \\
\hline Central African Republic & Costa Rica & France \\
\hline Chad & Dominican Republic & Germany \\
\hline Congo, Dem. Rp. & Ecuador & Iceland \\
\hline Côte d'Ivoire & El Salvador & Ireland \\
\hline Ethiopia & Guatemala & Italy \\
\hline Gabón & Guyana & Netherlands \\
\hline Ghana & Haiti & Norway \\
\hline Guinea Bissau & Honduras & Spain \\
\hline Kenya & Jamaica & Switzerland \\
\hline Lesotho & Nicaragua & United Kingdom \\
\hline Madagascar & Panama & \\
\hline Malawi & Paraguay & $\underline{\text { Middle East and North Africa (11) }}$ \\
\hline Mali & Peru & Algeria \\
\hline Mauritania & Trinidad and Tobago & Egypt \\
\hline Mauritius & Uruguay & Greece \\
\hline Mozambique & Venezuela, RB & Iran \\
\hline Niger & & Israel \\
\hline Nigeria & South Asia (5) & Jordan \\
\hline Rwanda & Bangladesh & Morocco \\
\hline Senegal & India & Portugal \\
\hline Sierra Leone & New Zealand & Syrian Arab Rep. \\
\hline South Africa & Pakistan & Tunisia \\
\hline Tanzania & Sri Lanka & Turkey \\
\hline \multicolumn{3}{|l|}{ Togo } \\
\hline Uganda & $\underline{\text { East Asia (14) }}$ & \\
\hline Zambia & Australia & \\
\hline \multirow[t]{13}{*}{ Zimbabwe } & China & \\
\hline & Fiji & \\
\hline & Hong Kong SAR & \\
\hline & Indonesia & \\
\hline & Japan & \\
\hline & Korea, Rep. & \\
\hline & Malaysia & \\
\hline & Nepal & \\
\hline & Papua New Guinea & \\
\hline & Philippines & \\
\hline & Singapore & \\
\hline & Taiwan Province of China & \\
\hline & Thailand & \\
\hline
\end{tabular}

Note: Country coverage varies by variable. 


\section{DESCRIPTION OF THE DATA}

Variable

Real GDP

Initial GDP per capita

Average schooling

Inflation

Government consumption

Terms of trade

Investment

Physical capital stock

Capital share

Institutional quality

\section{Definition and Sources}

In constant local currency units from World Development Indicators (WDI) for growth accounting exercises. In constant international prices from Penn World Tables (PWT) 6.1 for cross-country analyses.

\section{From PWT6.1}

Average years of schooling among males over 25, from Barro and Lee (2000).

Log difference of GDP deflator, from WDI.

General government final consumption expenditures, constructed from WDI and IFS data by Fatás and Mihov (2003).

From Bosworth and Collins (2003).

Real gross domestic investment, from Bosworth and Collins (2003).

From Bosworth and Collins (2003).

From Bosworth and Collins (2003).

ICRG 1982, from Knack and Kneefer (2003). 


\section{References}

Abimanyo Anggito (2000), “The Indonesia Economy and TFP," Singapore Economic Review, Vol. 40, no. 25.

Barro, Robert, and Jhang-Wha Lee (2000), "International Data on Educational Attainment: Updates and Implications," NBER Working Paper 7911.

Bevan David, Collier, Paul, and Gunning, Jan (1999), "Nigeria and Indonesia," Oxford University Press.

Booth, Anne, "The Oil Boom and After: Indonesian Economic Policy and Performance in the Soeharto Era," Oxford University Press, Singapore.

Bosworth, Barry, and Susan Collins (2003), "The Empirics of Growth: An Update." Brookings Paper on Economic Activity. Brookings Institution.

Hausmann, Ricardo, Pritchett Lant, and Rodrik Dani (2004), “Growth accelerations," John F. Kennedy School of Government, unpublished.

Hausmann, Ricardo, Rodrik Dani, and Andres Velasco (2005), "Growth diagnostics," John F. Kennedy School of Government, unpublished.

Knack, Stephen, and Philip Keefer (1995), "Institutions and Economic Performance: Crosscountry Tests Using Alternative Institutional Measure," Economics and Politics, Volume 7 , number 3.

Mody, Ashoka and Martin Schindler (2004), "Economic Growth in Turkey, 1960-99," Selected Issues, IMF Country Report.

Political Risk Services, “International Country Risk Guide,” ICRG XXI:9, PRS Group, New York.

Rodrik, Dani (1999b), "The Asian financial crisis and the virtues of democracy," Challenge, Vol. 42, no.4.

Rodrik, Dani, Arvind Subramanian, and Francesco Trebbi (2002), "Institutions Rule: The Primacy of Institutions over Geography and Integration in Economic Development," NBER Working Paper No. 9305, National Bureau of Economic Research.

Sarel, Michael (1997), "Growth and Productivity in ASEAN Countries," IMF Working Paper No. $97 / 97$.

Temple, Jonathan (2001), “Growing Into Trouble: Indonesia after 1966,” CEPR Discussion paper no. 2932. 


\section{Assessing Indonesia's Public Debt LeVel ${ }^{1}$}

\section{A. Introduction}

1. This chapter examines the issue of what would be an appropriate upper level of public debt for Indonesia. This is an important issue because: (i) the level of public debt can affect economic growth through its impact on the economy's vulnerability to shocks and the government's claims on financial resources for debt service; (ii) Indonesia's public debt and debt service ratios remain high and lingering weaknesses in the fiscal management framework, including an unstable and petroleum-dependent revenue base, add to the vulnerabilities stemming from fluctuations in the exchange rate and interest rates; and (iii) Indonesia's re-access to domestic and international credit markets has increased the prospects for market borrowing in the future.

2. The appropriate upper level of public debt is estimated by quantifying the public debt threshold at which significant economic events take place. These are the thresholds at which: (i) the potential for a crisis becomes significant-i.e., the "early warning signals" approach; (ii) the debt level would significantly reduce growth ${ }^{2}$ - i.e., the "debt overhang and growth" approach; and (iii) the future debt level would become unsustainable for given shocks to macroeconomic variables - i.e., the "stochastic debt sustainability" approach. By focusing on public debt, this study differs from most other debt threshold studies, which have looked at external debt and examined episodes of large external debt reductions. There have been few empirical studies of public debt sustainability, mainly because of the difficulty in obtaining reliable and comparable cross-country time series data on public debt. ${ }^{3}$

\section{This study's empirical results suggest an upper level for public debt in the 35-}

42 percent of GDP range for Indonesia. Though this result needs to be interpreted with caution, it is comparable to results of other studies on external debt thresholds. ${ }^{4}$ Thus, while showing that "safe" debt thresholds vary from country to country and depend on history, Reinhart, Rogoff and Savastano (2003) found that the risk of a credit event increases significantly when the external debt to GNP ratio exceeds the 30 to 35 percent of GNP range in a debt intolerant country (i.e., a country with a relatively low institutional investor rating). Patillo, Poirson, Ricci $(2002,2003)$ find that external debt levels above 35-40 percent of

\footnotetext{
${ }^{1}$ Prepared by Amine Mati (FAD).
}

${ }^{2}$ For example, by reducing productive public expenditure or by depressing private investment as a result of higher interest rates and/or expectations of higher taxes in the future.

${ }^{3}$ A notable attempt was made in the 2003 World Economic Outlook study, which presents a comprehensive dataset on public sector debt.

${ }^{4}$ Thresholds found often vary across country samples and time periods and are highly dependent on the specification used. 
GDP are detrimental to growth. IMF (2003) finds that external debt thresholds of 40 percent for the average emerging market and below 55 percent of GDP for low-income countries are appropriate.

\section{B. The Characteristics of Indonesia's Public Debt}

\section{Indonesia's public debt ratio jumped during the crisis, followed by a partial} reversal in subsequent years. The public debt ratio increased from about 30 percent of GDP in 1995 to 54 percent of GDP in 2004. The debt ratio peaked at 92 percent of GDP in 2000, with the increase mostly reflecting bank restructuring costs in the wake of the financial crisis and further depreciation of the currency in 2000 (of some 30 percent). Since then, economic recovery, fiscal consolidation, and lower interest rates have helped reduce the debt ratio.
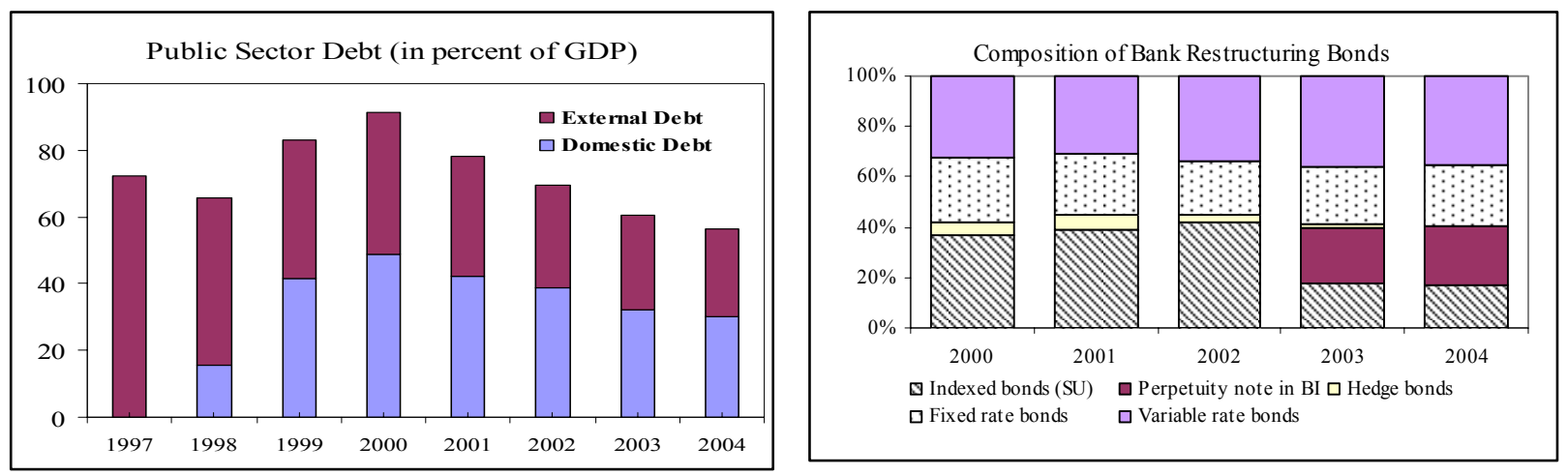

5. The government has improved the debt structure, but it still entails substantial exchange rate and interest rate risk. While the foreign currency denominated debt has been declining, to represent about 49 percent of all government debt in 2004, and is held mainly by official creditors, such a high proportion still implies that exchange rate fluctuations have a sizable impact on the debt level and debt service. ${ }^{5}$ Moreover, 54 percent of outstanding government bonds carry variable interest rates, which leaves the government highly vulnerable to interest rate shocks. The government has made substantial progress in improving the structure of its tradable debt, by lengthening the duration of debt through debt buybacks and exchanges, smoothing the debt service profile and substantially reducing rollover risks; the average maturity of the domestic bond portfolio is currently about 7.2 years.

\footnotetext{
${ }^{5}$ Only 4 percent of total domestic government bonds are held by foreigners. Multilateral creditors represent about 25 percent of all external debt, with the rest held by Paris Club creditors.
} 
6. Debt service costs remain high. While total debt service costs declined to about 6 percent of GDP in 2004, public debt service still represented as much as 53 percent of non oil revenues and 42 percent of primary spending, with the interest bill alone accounting for about one fifth of total spending. The heavy debt burden has hampered the government's ability to boost spending in priority sectors such as health, education, and infrastructure.

\section{Indonesia's public debt ratio has converged toward the regional average but} may still be on the high side. The September 2003 World Economic Outlook study showed that public debt had grown across emerging markets, to about 72 percent of GDP in 2002. While this is substantially higher than Indonesia's present debt ratio, Indonesia is broadly at par with the regional average. The September 2003 WEO notes, however, that major recent default cases and financial crises have occurred even with a public debt ratios below 45 percent of GDP. ${ }^{6}$

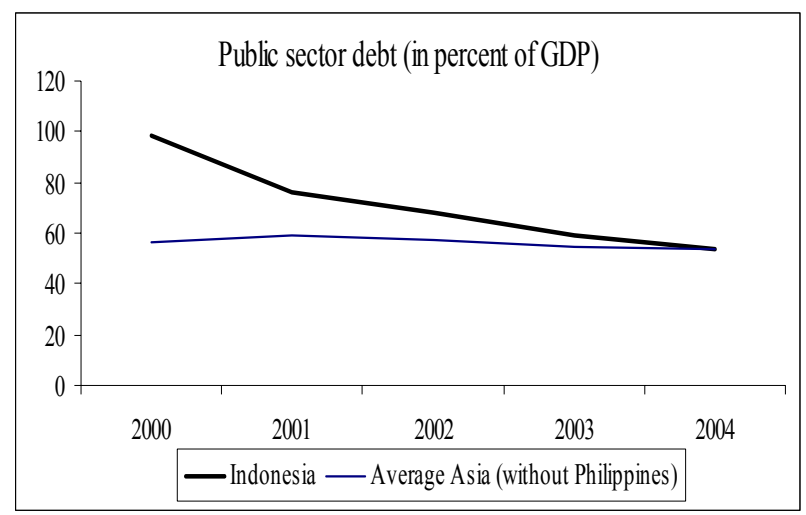

\section{Debt Threshold and Vulnerability: an Application of the Early Warning System}

8. One yardstick used to measure debt intolerance is the public debt level associated with a currency crisis through the application of the early warning system (EWS). EWS studies typically monitor the evolution of a number of economic indicators that tend to behave differently in a systematic manner prior to a crisis. Such an analysis involves the use of a non-parametric method and high-frequency data. Results have tended to show that external debt levels (either as percent of total exports or GDP) are good predictors of currency crises. ${ }^{78}$ A high debt level could exacerbate capital account problems and lead to capital flight if it raised concerns about debt sustainability.

9. The EWS methodology requires a precise definition of a crisis and a method for generating predictions. The empirical analysis used in this chapter concentrates on a sample of 14 emerging markets in Latin America and Asia, with monthly data interpolated from

\footnotetext{
${ }^{6}$ For example the public debt to GDP ratio was 28 percent of GDP in Indonesia, 36 percent of GDP in Thailand, and 45 percent of GDP in Argentina before the onset of the crisis (see 2003 WEO).
}

${ }^{7}$ See Kaminsky and Reinhart (1998); Al-Mashat and Mati (2003); and Berg and Patillo (1999).

${ }^{8}$ Although not always accompanied by debt defaults (Roubini et al.). 
yearly and quarterly data for $1990-2002 .{ }^{9}$ The following method was employed to define the threshold:

- Crisis period: A crisis is defined as "a situation in which an attack on the currency leads to sharp currency depreciations, large losses in reserves or a combination of both." Months in which a weighted index of these variables is above the mean by more than three standard deviations are defined as crises. ${ }^{10}$

- Threshold identification. The public debt to GDP ratio, $X^{j}$, is said to signal a crisis in period $t$ if the public debt to GDP ratio crosses the critical threshold point $\overline{X_{t}^{j}}$. The threshold is defined in relation to percentiles of the distribution of the indicator.

- Critical threshold: The critical threshold itself is found by performing a grid search from the 10th to the 40th percentiles of the public debt variable and selecting the value that minimizes the noise-to-signal ratio (i.e., the number of false signals relative to good signals). Any noise to signal ratio greater than one leads to bad predictors as the indicator will be giving more false signals than accurate ones. Any such indicator should be excluded from the analysis.

\section{The application of the EWS methodology to the sample of emerging markets} shows that:

- The public debt to GDP ratio is a good crisis predictor. This is indicated by its minimum noise to signal ratio of about 0.9 .

- $\quad$ For Indonesia, the analysis points to an upper debt ratio of 42 percent of GDP. This result is derived from the minimum noise-to-signal ratio corresponding to the $34^{\text {th }}$ percentile of the debt variable, which in the case of Indonesia corresponds to a debt-to-GDP ratio of 42 percent of GDP.

- The use of this threshold to signal a currency crisis should be nuanced, as it is associated with an unconditional probability of a crisis of only 11 percent. ${ }^{11}$ Other

\footnotetext{
${ }^{9}$ Several methods of interpolation were used, including a linear trend, log, and exponential. As shown in Kaminsky and Reinhart, interpolation can be justified given the "persistence" of the debt variable. Data used was from WEO, supplemented by higher-frequency data from Harvath Analytica.

10 The 24 months prior to the currency crisis itself represent the crisis periods.

${ }^{11}$ Calculated as the number of monthly good signals divided by the total number of months in the crisis period.
} 
caveats associated with the method are that the composition of debt may make a difference (e.g., Indonesia's large share of official creditors may point toward a higher threshold), and that many false signals are still possible.

\section{Debt Overhang and Growth}

\section{The second approach to gauging the appropriate public debt level assesses the} link with economic growth. The theoretical rationale for such a link is that at relatively low levels of debt, borrowing may have a positive impact on growth through increased investment, leading to higher transitional growth (Eaton, 1993). On the other hand, higher debt levels would be expected to lead to a higher tax burden in the future, which would lead to lower investor expectations of after-tax returns, thereby lowering investment and growth (Krugman (1988); Agenor and Montiel (1996)). By the same token, a higher debt level would tend to limit resources available for spending on productive activities because of the debt service burden, and to crowd-out the private sector from credit markets.

\section{The empirical literature linking growth and debt has concentrated on external} debt. Elbadawi (1997) found a growth maximizing external debt to GDP ratio of 97 percent, which seems quite high. More recent papers by Patillo et al. (2002) found that external debt levels above the 35-40 percent of GDP range might be detrimental to growth. None of the previous studies have estimated the empirical relationship between public debt and growth.

\section{The empirical analysis presented below uses annual panel data for $\mathbf{5 1}$ countries} covering 1972 to 2002. The data was collected from WEO and the World Bank Development Indicators, and complemented by the Patillo, Poirson and Ricci (2003) dataset. The analysis used three-year averages of annual growth data in order to allow for a smoothing of short run fluctuations and business cycles effects. The results conform to those shown in studies on external debt. The results could be further tested for robustness by separating the sample between the countries having access to capital markets and those that do not, and by using a more comprehensive public debt data series spanning the last three decades. ${ }^{12}$

${ }^{12}$ The extensive public debt data obtained for the WEO (2003) are on a general government basis for industrial countries, and were constructed as a sum of separate series for external and domestic public debt. Note that this data set is different from the one used in section C, as domestic debt data is mostly central government data (with a longer time series). 


\section{The empirical analysis suggests that debt and long-term growth were negatively}

correlated. Such a relationship is present linearly but also in a multivariate setting after controlling for other factors that affect growth, such as terms of trade, population growth rates and fiscal balance, and is consistent across different specifications (Table). ${ }^{13}$ The results imply that an increase in the debt to GDP ratio by 2.7 percent would reduce growth on average by about 1 percent. ${ }^{14}$ These results hold for Indonesia, as suggested by the insignificant coefficient on the interactive debt dummy.

\section{The methodology was then} refined in order to identify the debt level at which the overall impact on growth becomes negative. That is, the analysis seeks to determine the level from which any increase in debt would lead to lower growth. To this end, the following regression was estimated:

\begin{tabular}{|c|c|c|c|c|c|c|}
\hline \multicolumn{7}{|c|}{ Effect of Public Sector Debt on Growth } \\
\hline & OLS & & IV & & $\mathrm{FE}$ & \\
\hline Log (Lagged income) & $\begin{array}{c}-1.56 \\
(-4.76)\end{array}$ & $* * *$ & $\begin{array}{c}-0.75 \\
(-1.88)\end{array}$ & $*$ & $\begin{array}{c}-8.53 \\
(-8.25)\end{array}$ & $* * *$ \\
\hline Terms of Trade & $\begin{array}{l}0.045 \\
(2.87)\end{array}$ & $* * *$ & $\begin{array}{l}0.053 \\
(3.14)\end{array}$ & $* * *$ & $\begin{array}{c}0.03 \\
(2.03)\end{array}$ & * \\
\hline Log (pop. Growth) & $\begin{array}{c}-4.32 \\
(-3.27)\end{array}$ & $* * *$ & $\begin{array}{c}-4.49 \\
(-3.07)\end{array}$ & $* * *$ & $\begin{array}{c}-6.6 \\
(-1.51)\end{array}$ & \\
\hline Debt service/exports & $\begin{array}{l}-0.004 \\
(-0.47)\end{array}$ & & $\begin{array}{l}-0.016 \\
(-1.44)\end{array}$ & & $\begin{array}{l}0.001 \\
(0.16)\end{array}$ & \\
\hline Log (schooling) & $\begin{array}{l}1.08 \\
(3.48)\end{array}$ & $* * *$ & $\begin{array}{l}0.95 \\
(2.5)\end{array}$ & $* *$ & $\begin{array}{c}0.69 \\
(0.388)\end{array}$ & \\
\hline Log (investment) & $\begin{array}{l}3.27 \\
(5.2)\end{array}$ & $* * *$ & $\begin{array}{c}0.9 \\
(1.13)\end{array}$ & & $\begin{array}{c}3.95 \\
(4.64)\end{array}$ & $* * *$ \\
\hline Fiscal balance & $\begin{array}{c}0.1 \\
(2.28)\end{array}$ & $* *$ & $\begin{array}{l}-0.014 \\
(-0.19)\end{array}$ & & $\begin{array}{c}0.19 \\
(4.34)\end{array}$ & $* * *$ \\
\hline Openess & $\begin{array}{c}0.02 \\
(1.53)\end{array}$ & & $\begin{array}{l}0.018 \\
(1.13)\end{array}$ & & $\begin{array}{l}0.09 \\
(2.6)\end{array}$ & $* * *$ \\
\hline $\log (\mathrm{debt} / \mathrm{GDP})$ & $\begin{array}{c}-1.15 \\
(-4.48)\end{array}$ & $* * *$ & $\begin{array}{c}-0.78 \\
(-2.43)\end{array}$ & $* *$ & $\begin{array}{c}-0.81 \\
(-2.23)\end{array}$ & $* *$ \\
\hline Indonesia debt interactive dummy & $\begin{array}{c}0.21 \\
(0.97)\end{array}$ & & $\begin{array}{c}0.59 \\
(2.23)\end{array}$ & $* *$ & & \\
\hline Constant & $\begin{array}{l}12.77 \\
(3.24)\end{array}$ & $* * *$ & $\begin{array}{l}12.59 \\
(2.5)\end{array}$ & $* *$ & & \\
\hline R-Square & 0.27 & & 0.2 & & 0.55 & \\
\hline Number of observations & 394 & & 380 & & 394 & \\
\hline
\end{tabular}

$$
y_{i t}=\alpha_{i t}+\beta X_{i t}+\sum_{j=2}^{5} \lambda_{j} D_{j}+\varepsilon_{i t}
$$

Where y is growth in income per capita, X represents factors controlling for growth, and $\mathrm{Dj}$ represents debt dummy variables divided into quintiles (see Table for different thresholds, which were established by ranking all debt observations and establishing thresholds corresponding to each quintile). The regression results should be interpreted by assessing the effect of debt on growth in comparison to the lower quintile. They indicate that debt levels belonging to the third, fourth, and fifth dummy would reduce the growth level, implying that

${ }^{13}$ OLS, Instrumental variables (using two stage least squares to instrument for endogeneity in the schooling, openness, investment and public debt variables) and fixed effects were all used. Time dummies were included for the crisis period (1997-1998). The estimated effects of variables on growth are all of the expected sign, except openness and debt service to exports. Patillo, Poirson, and Ricci (2002) find similar results, using the same approach.

14 The effect would still be significant but smaller using instrumental variables. 
debt levels above 38 percent of GDP would be detrimental to growth. ${ }^{15}$ The introduction of an Indonesia dummy variable interacted with the debt quintile dummies do not change the result.

\begin{tabular}{|c|c|c|c|c|c|c|}
\hline \multicolumn{3}{|c|}{ Debt Thresholds Identified } & \multicolumn{4}{|c|}{ Effect of Debt Quintiles on Growth 1/ } \\
\hline & \multirow{2}{*}{$\begin{array}{l}\text { Number of } \\
\text { observations }\end{array}$} & \multirow{2}{*}{ Thresholds } & & OLS & IV & FE \\
\hline & & & \multirow[t]{2}{*}{ Quanti } & \multirow{2}{*}{$\begin{array}{l}-0.16 \\
0.751\end{array}$} & \multirow{2}{*}{$\begin{array}{l}-0.38 \\
(-0.69)\end{array}$} & \multirow{2}{*}{$\begin{array}{c}-0.11 \\
(-0.23)\end{array}$} \\
\hline & & & & & & \\
\hline OLS and fixed effects & & & Quantile 3 & $-1.59 * * *$ & $-1.04 *$ & 0.08 \\
\hline Quintile 1 & 79 & 0 & & -3.09 & $(-1.92)$ & $(0.49)$ \\
\hline Quintile 2 & 79 & 23.2 & Quantile 4 & $-1.59 * * *$ & $-2.32 * * *$ & -0.63 \\
\hline Quintile 3 & 79 & 37.6 & & $(-3.09)$ & $(-3.82)$ & $(-1.05)$ \\
\hline Quintile 4 & 79 & 53.1 & Quantile 5 & $-1.73 * * *$ & $-2.57 * * *$ & -0.43 \\
\hline \multirow{2}{*}{ Quintile 5} & 78 & 77.3 & & $(-3.16)$ & $(-4.01)$ & $(-0.66)$ \\
\hline & & & Interactive Indonesia Dummy 3/ & 1.69 & 1.57 & 0.95 \\
\hline Instrumental Variables & & & & $(0.77)$ & 1.4 & 0.45 \\
\hline Quintile 1 & 76 & 0.0 & & & & \\
\hline Quintile 2 & 76 & 23.4 & \multirow{5}{*}{\multicolumn{4}{|c|}{$\begin{array}{l}\text { Note: Values of Robust t statistics are in parentheses. } \\
* * *, * *, * \text { represent significance level at the } 1,5 \text {, and } 10 \text { percent } \\
\text { confidence levels, respectively. } \\
\text { 1/ Coefficient is with respect to Quintile } 1 \text { dummy. } \\
\text { 2/ Control variable coefficients are consistent with those found on page } 6 \text {. } \\
3 \text { / Interacted with debt dummy of the second guintile. }\end{array}$}} \\
\hline Quintile 3 & 76 & 37.9 & & & & \\
\hline Quintile 4 & 76 & 53.1 & & & & \\
\hline Quintile 5 & 76 & 77.9 & & & & \\
\hline $\begin{array}{l}\text { 1/ Each quintile is shown by } \\
\text { Quintile } 1 \text { under OLS had d }\end{array}$ & $\begin{array}{l}\text { nimum value. } \\
\text { P ratios betwe }\end{array}$ & $\begin{array}{l}\text { or example, } \\
\text { en } 0 \text { and } 23.2\end{array}$ & & & & \\
\hline
\end{tabular}

16. The inclusion of additional factors in the analysis could potentially have affected the appropriate debt range chosen. A number of studies have found that countries with better institutions experience stronger growth, which boosts revenues and eases the debt servicing burden, while weak political systems often delay fiscal adjustment and accumulate short-term debt. ${ }^{16}$ Low government revenues, as in the case of Indonesia, would also imply that governments will often have difficulty meeting their desired expenditures, thereby increasing the pressure to borrow. In addition, a different composition of the debt structure including its financing and maturity would have affected the appropriate debt level chosen.

\section{E. Stochastic Debt Sustainability}

17. The third measure of debt intolerance looks at the effects of stochastic shocks on the debt level. The basic premise of this method is that a country's public debt is deemed sustainable as long as the public debt to GDP ratio remains constant at its current level or

15 The differential impact on growth is very sensitive to time dummies used for crisis periods, and does not seem to hold under the fixed-effects specification.

${ }^{16}$ IMF (2003), Von Hagen and Harden (1995). See also Chapter II of this volume. 
declines over time even under adverse circumstances. ${ }^{17}$ Debt dynamics are modeled in the following way:

$$
d_{t+1}-d_{t}=\frac{1}{(1+g+\pi+g \pi)}(\hat{r}-\pi(1+g)-g+\varepsilon \alpha(1+\hat{r})) d_{t}-p b_{t+1}
$$

where $d$ is the debt-to-GDP ratio, $p b$ is the primary balance, $\hat{r}$ is a weighted average of domestic and foreign interest rates, $\alpha$ is the share of foreign-currency denominated public debt, $\pi$ is the change in the domestic GDP deflator, and $g$ is the real GDP growth rate. Changes in the exchange rate (local currency per U.S. dollar) are denoted by $\varepsilon$, with $\varepsilon>0$ indicating a depreciation of the local currency.

\section{Debt sustainability is assessed based on projections of key variables affecting}

future debt ratios. The method postulates that the net present value of the primary surplus must equal today's debt to GDP ratio as a condition for debt sustainability. Underlying variables such as interest rates, economic growth, and the primary surplus, are projected. The appropriate debt threshold would be the medium-term debt target that would be resilient to "reasonable" adverse circumstances (such as shocks to individual variables of one or two standard deviations, or alternative scenarios that combine several shocks).

19. The analysis suggests that Indonesia's debt position would be sustainable with a public debt ratio of about 35 percent of GDP or less. Again, this is based on the premise that the public debt is sustainable as long as the debt-to-GDP ratio is projected to remain constant at its current level (a little above 50 percent of GDP) or declining, even when the economy is subject to "normal" shocks. The 35 percent of GDP threshold is predicated in the baseline medium-term scenario presented in the staff report and would be sensitive to changes in underlying assumptions. Under the baseline scenario,

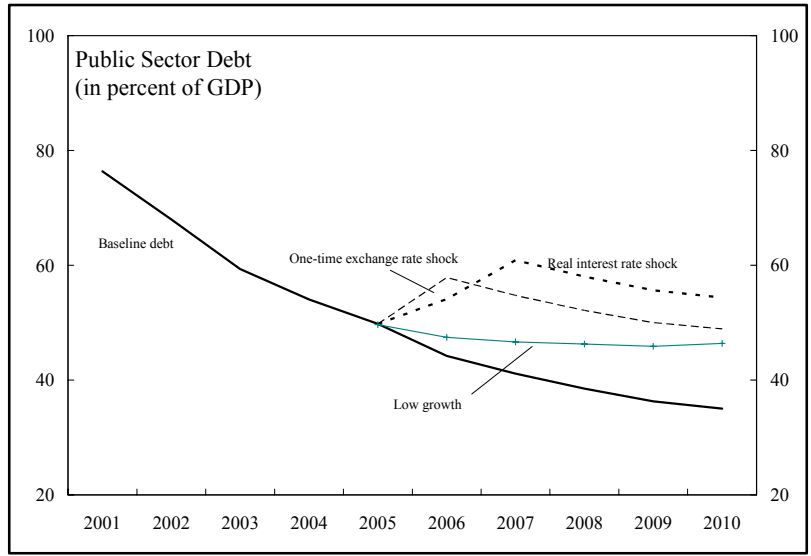
a debt level of 35 percent of GDP or less would be sustainable under the following (see figure):

- If the exchange rate depreciated by 30 percent in 2006, the debt level would remain at about 50 percent of GDP in 2010.

\footnotetext{
${ }^{17}$ This is the approach used in the standard debt sustainability analysis included in IMF staff reports.
} 
- A temporary upward shock to the real interest rate, by two standard deviations above its historical average in 2006 and 2007, would raise the debt ratio to 54.3 percent of GDP by 2010.

- A combination of permanent slowdown in growth, to 3.5 percent in the medium term and the lowering of the primary fiscal deficit to the 0.5-1 percent of GDP range, would lead to a 2010 debt ratio of 51 percent of GDP.

\section{F. Conclusions}

20. The empirical analysis above suggests that Indonesia's current public debt level is on the high side and that the government's medium-term debt target would bring debt to a "safe" level. Indeed, while it is not possible to arrive at precise estimates of the appropriate upper public debt level, and drawbacks exist for each method utilized above, the analysis suggests that Indonesia's "safe" debt level would be in the 35-42 percent of GDP range or below. This confirms that the current public debt level is on the high side, while also lending support to the government's 32 percent of GDP target for 2009. 


\section{References}

Agenor and Montiel (1996), Development Macroeconomics, Princeton.

Al-Mashat and Mati (2004), "Currency crises in the Middle East North Africa (MENA) Region: What are the Early Warning Signals"? Proceedings of the Conference on "Rising Challenge: International Crisis and Economic Management in Egypt."

Barro (1979), "On the determination of Public Debt,” Journal of Political Economy.

Berg and Patillo (2000), "The Challenges of Predicting Economic Crises," Economic Issues, No. 22), International Monetary Fund.

Eaton (1993), "Sovereign Debt: A Primer," World Bank Economic Review, Vol. 7, No. 2, pp. 137-172.

Elbadawi, et al (1997), "Debt Overhang and Economic Growth in Sub-Saharan Africa," External Finance For Low Income Co, IMF institute, Washington DC.

Hemming, Kell, Schimmelpfennig (2003). "Fiscal Vulnerability and Financial Crisis in Emerging Market Economies,” Occasional Papers, 218, International Monetary Fund.

International Monetary Fund (2002), “Assessing sustainability,” (www.imf.org) (2003), World Economic Outlook, Public Debt in Emerging Markets: Is it too high? Washington DC.

Kaminsky, Lizondo and Reinhart (1999), "The Twin Crises: The Causes of Banking and Balance of Payments Problems," American Economic Review.

(1998), "Leading Indicators of currency crises," IMF Staff Papers, International Monetary Fund, Washington DC.

Kraay and Vikram Nehru (2003), “When is External Debt Sustainable?” Work Bank.

Manasse Roubini (2005), "Rules of Thumb for Sovereign Debt Crises," IMF Working paper. International Monetary Fund.

and Axel Schimmelpfennig (2003), "Predicting Sovereign Debt Crisis," IMF Working Paper, WP/03/221.

Patillo, Poirson, and Ricci (2002), "External Debt and Growth,” IMF Working Paper. International Monetary Fund. 
(2003), "What Are The Channels Through Which External Debt Affects Growth? Brookings Trade Forum, pp 229-58.

Reinhart, Rogoff and Miguel Savastano (2003), “Debt Intolerance,” Brookings Papers on Economic Activity.

Von Hagen and Harden (1995). "Budget processes and Commitment to Fiscal Discipline," European Economic Review, Vol. 39, April, pp. 771-779. 


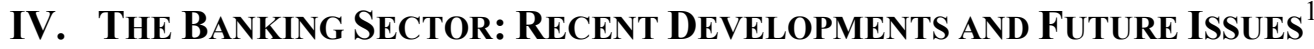

\section{A. Introduction}

1. The Indonesian banking sector has been slowly recovering since the Asian crisis. Measures undertaken during the crisis have on the whole been successful. ${ }^{2}$ Since then, the level of capitalization, profitability and liquidity of the overall banking sector has continued to improve, and bank credit growth have gained momentum in recent years, although bank intermediation has recovered slowly.

\section{As Indonesian banks gradually resume their role as financial intermediaries,} they may be entering a phase of increasing risks. These risks arise from growing lending activity and increasing competition that may put pressure on asset quality and margins. The banks' capacity to manage these risks, as well as the supervisors' ability to oversee risk management practices, will determine the future vulnerability of the sector and its scope for supporting economic growth.

3. This chapter reviews recent developments in the banking sector, and assesses the sector outlook going forward. To these ends, it analyzes the supply and demand factors underlying recent trends in bank credit, assesses the main risks and vulnerabilities facing the banking sector, and discusses policy measures to address these issues.

\section{B. Structure, Performance, and Vulnerabilities}

\section{The structure of the financial sector has remained broadly unchanged since 2003}

\section{Indonesia's financial sector is}

\section{dominated by banks, a substantial} proportion of which are state-owned or statecontrolled (Table 1 and Text Chart). Following the dramatic reduction in the number of banks from 238 in 1997 to 138 in 2003, and the privatization of significant shares in banks, the banking system's structure has remained relatively stable. The 15 largest banks account for about 70 percent of banking assets, while state banks and regional development banks
Indonesia: Financial System Structure, 2004

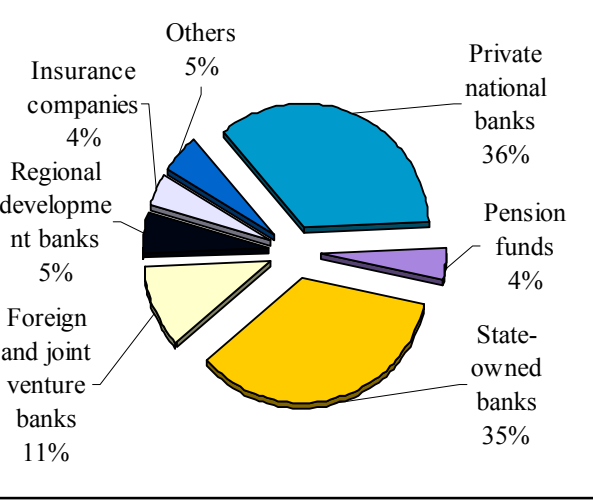

${ }^{1}$ Prepared by Geremia Palomba (APD) and Leslie Teo (MFD).

${ }^{2}$ See Cole and Slade (1998), Enoch et al. (2001), Pangestu and Habir (2002), and Seelig et al. (2004) for a detailed discussion of these measures. 
account for about 46 percent (41 percent state banks, 5 percent regional development banks). ${ }^{3}$ Conversely, about 75 small banks each have assets below Rp 1 trillion and a market share of less than 0.1 percent. The weight of nonbank financial institutions (NBFIs) - finance companies, mutual funds, pension funds, and insurance companiesremains limited, although they have recently shown significant asset growth.

\section{Bank intermediation has recovered slowly, while banks' financial performance has improved}

5. Over recent years, Indonesia has experienced significant growth in bank credit and a shift toward consumer lending. Over the period 2000-2004, annual loan growth averaged about 19 percent on a gross nominal basis, far outpacing growth in neighboring countries. Mirroring the strong growth in domestic consumption, banks have focused more on consumer lending and have moved away from lending for investment and working capital. In doing so, they have made a marked shift from the pre-crisis period, when their focus was almost entirely on lending to large corporations.

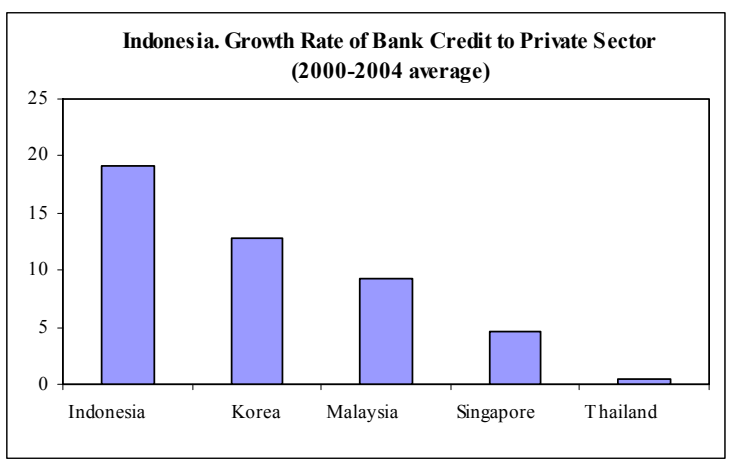

\begin{tabular}{|lrrrrr|}
\hline \multicolumn{5}{|c|}{ Indonesia. Bank Credit Allocation, 2000-2004 } \\
\hline \multicolumn{7}{|c}{2000} & 2001 & 2002 & 2003 & 2004 \\
\hline Total index & 100 & 114 & 136 & 163 & 206 \\
Consumption & & & & & \\
$\quad$ Index & 100 & 146 & 199 & 280 & 376 \\
$\quad$ Share & 15 & 19 & 22 & 26 & 27 \\
Investment & 100 & 113 & 127 & 144 & 179 \\
$\quad$ Index & 61 & 57 & 55 & 53 & 52 \\
Share & & & & & \\
Working capital & 100 & 107 & 124 & 142 & 175 \\
Index & 24 & 24 & 23 & 22 & 21 \\
Share & & & & & \\
\hline
\end{tabular}

6. The level of credit compared to the size of the economy appears, however, modest and bank intermediation overall has recovered slowly. The banks credit to the private sector (BCPS) ratio in Indonesia remains slightly above 20 percent and is significantly lower than in neighboring countries. Assessment of the recent credit growth should also consider the low base which the country is coming from; at end2000, loans were just 24 percent of total

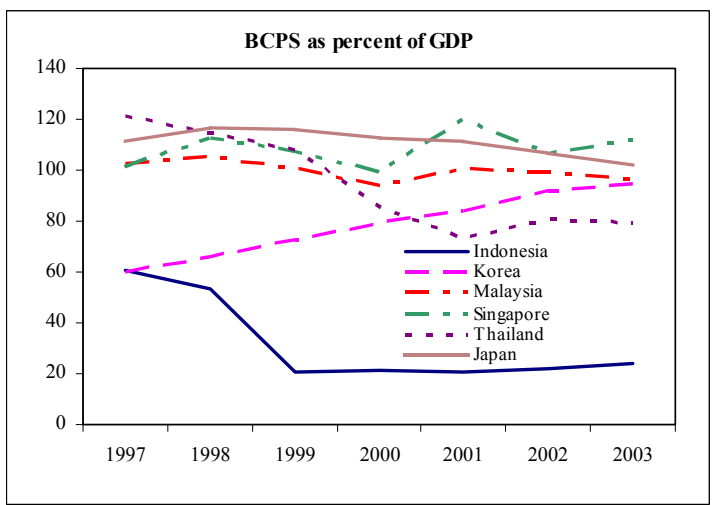
assets (due to the substantial loan write-off

${ }^{3}$ The 26 regional development banks are owned by provincial governments, and have expanded rapidly on the back of fiscal decentralization. 
during the crisis and the accumulation of recapitalization bonds) before growing to 42 percent by end-2004 - versus about 70 percent before the crisis. Concurrently, banks' recapitalization bond holdings have decreased from 56 percent of total assets at end-2000 to about 30 percent at end-2004, partly reflecting overall nominal asset growth, and partly sales of bonds in the secondary markets and to mutual funds.

\section{With renewed credit growth, the ratio of nonperforming loans has improved} and profitability recovered, while capital adequacy has remained high (Figure 1, Table 2). ${ }^{4}$ Over the last few years, the nonperforming loans (NPL) ratio has continued to decline and reached about 4 percent at end-2004, driven largely by an expansion in loans. Profitability has been buoyant, with after tax net income-to-average equity (ROAE) at end2004 as high as 26 percent due to robust credit growth, large margins, and lower loan loss provisions. At the same time, capital has remained high, with the sector capital adequacy ratio (CAR) around 21 percent at end-2004.

8. Indonesian banks' financial performance compares favorably in the context of the ASEAN region. ${ }^{5}$ Indonesian banks have higher net interest margins, underpinning their profitability. Capital (as measured by the equity-to-total assets ratio) is about average, while costs are among the lowest. However, Indonesian banks have the lowest share of loans to assets ratio in the ASEAN context, reflecting the relatively more severe impact of the crisis (Figure 2).

9. Market indicators of performance have improved, reflecting robust valuations. Distance-to-default (DD) measures for large listed banks, for instance, significantly increased during 2004 reflecting improved equity prices and stronger bank financial conditions (Figure 3). The DD measures the number of standard deviations a bank's asset value is away from "default" (i.e., the firm's assets are less than its current book value of liabilities). The smaller the DD the higher the probability of default. ${ }^{6}$

\section{These registered improvements in financial performance may, however, overstate the actual improvements.}

10. The above trends should be interpreted carefully, as the standard financial ratios may overstate banks' performance and soundness. On asset quality, new asset

\footnotetext{
${ }^{4}$ The data presented cover the top 15 banks until end-December 2004. Note that although there has been some improvement since the crisis, the quality of banks' financial statements remains uneven.

${ }^{5}$ Indonesia, Malaysia, Singapore, Thailand, and the Philippines.

${ }^{6}$ These calculations are based on daily equity prices and annual accounting data, following the Black-Scholes' option pricing model.
} 
classification rules introduced in early 2005 are likely to lead to higher reported NPLs. Moreover, a more complete measure than the NPLs is the compromised asset ratio, which at end-2004 remained high at 13 percent for all banks (mainly concentrated in state banks, see text table), although it has also been declining. ${ }^{7}$ Also, the recent strong profitability relies on high spreads that may not last given the increasing competition, especially in consumer lending. Finally, although banks' capital adequacy ratio is high, it may reflect low risk-weighted assets as banks' substantial holdings of government bonds are zeroweighted and loans to stateowned companies are given only a 50 percent risk-weight. Alternative measures of capital, such as equity to total assets, seem adequate in comparison to peer banks, but

\begin{tabular}{|c|c|c|c|c|}
\hline \multicolumn{5}{|c|}{ State and Private Banks' Financial Soundess Indicators, December 2003-04 1/ } \\
\hline & \multicolumn{2}{|c|}{2003} & \multicolumn{2}{|c|}{2004} \\
\hline & $\begin{array}{l}\text { Private } \\
\text { banks }\end{array}$ & $\begin{array}{l}\text { State } \\
\text { banks }\end{array}$ & $\begin{array}{c}\text { Private } \\
\text { banks }\end{array}$ & $\begin{array}{c}\text { State } \\
\text { banks }\end{array}$ \\
\hline Capital adequacy ratio & 22.5 & 22.2 & 21.2 & 20.6 \\
\hline Loan growth (q/q) & 24.6 & 17.8 & 28.6 & 24.2 \\
\hline Equity/assets & 9.5 & 8.1 & 10.0 & 10.1 \\
\hline Core earnings/average assets & 2.5 & 2.4 & 2.9 & 3.0 \\
\hline NPLs/total loans & 4.9 & 6.4 & 3.0 & 5.1 \\
\hline Compromised assets/total loans & 10.7 & 23.2 & 7.0 & 18.2 \\
\hline Net compromised assets/Tier 1 capital & 18.5 & 65.2 & 17.6 & 62.3 \\
\hline Loan-loss reserves/compromised assets & 66.8 & 35.3 & 54.6 & 39.8 \\
\hline Liquid assets/total assets & 25.8 & 11.1 & 20.5 & 11.1 \\
\hline
\end{tabular}
may be also not fully capture the specific risks in the Indonesian banking system.

\section{State banks' financial performance has been less favorable than that of private} banks. With the exception of BRI, lending growth rates and financial performance of state banks are generally less favorable than that of private banks. State banks have compromised assets more than twice those of private banks, as they have made less progress in cleaning up their loan portfolios, partly because of restrictions on the type of restructuring that they may undertake. ${ }^{8}$ In addition, weaker lending and risk management practices and shareholder oversight in state banks create vulnerabilities that may lead to future NPLs, especially in an environment where lending (e.g., for infrastructure and to support economic growth) is being encouraged. State banks also have significantly less liquid assets than private banks, and their capital adequacy positions are more likely to be overstated because of their larger bond holdings and lending to state-owned companies.

\section{Despite recent improvements, there is scope for strengthening corporate governance and risk management...}

\footnotetext{
${ }^{7}$ Net compromised assets include reported NPLs, restructured loans currently categorized as pass or special mention, foreclosed real estate, and equities obtained under debt-equity swaps.
}

${ }^{8}$ The government recently issued a new regulation to facilitate resolution of nonperforming state bank loans through write-offs. 


\section{Governance practices, including in state-owned banks, could be further}

improved (Box III.1). While financial restructuring is more or less complete, banks still have some way to go in improving internal governance and operations, including corporate governance, internal controls, risk management, and management information (MIS) and information technology (IT) systems. Weaknesses are most notable in state banks where management does not always have a clear strategic mandate, shareholder oversight is sometimes less effective, and outside interference is more likely. Indeed, in the last couple of years, three of the largest state banks have seen major cases of fraud. The recent changes in management at state banks should provide impetus to a renewed effort to strengthen governance. In contrast, strategic investors in private banks identified weaknesses early in the reform process and have made substantial investments to improve governance, bringing in professional managements with international experience.

\section{Risk management capacity and procedures in large banks are being upgraded,} although full implementation will take time. Banks are making efforts to improve risk management, and many of the larger banks aim to be ready for Basel II by 2008. However, implementing these changes will require a sustained effort, as they involve a major shift in the way banks are operated.

\section{... as well as enhancing the legal and information environment}

\section{The operating environment for banks remains difficult despite recent}

improvements. The establishment of a credit reference bureau is a positive development toward sharing information covering bank's debtors. However, governance and transparency in the corporate sector is not always up to standard, making it difficult for banks to assess a borrower's true financial condition. The broader legal system also has shortcomings, with a bearing on banks' operations. For instance, the bankruptcy process is slow, with courts tending to favor debtors, hence increasing moral hazard behavior and banks' losses in the event of default. Against this background, corruption and fraud remain important concerns.

\section{These structural weaknesses help} explain why the Indonesian banking system faces lingering fragilities. The system continues to be rated among the lowest in the region (see Table), even after taking into account Indonesia's sub-investment sovereign rating.

\begin{tabular}{|c|c|c|c|}
\hline \multicolumn{4}{|c|}{ Moody's Weighted Average Bank Financial Strength Index 1/ } \\
\hline & Dec. 2002 & Dec. 2003 & Dec. 2004 \\
\hline China & 10.0 & 10.0 & 10.0 \\
\hline Hong Kong SAR & 62.3 & 62.3 & 62.3 \\
\hline India & 27.5 & 27.5 & 24.2 \\
\hline Indonesia & 3.0 & 3.0 & 7.3 \\
\hline Korea & 16.7 & 18.3 & 18.3 \\
\hline Malaysia & 31.7 & 33.3 & 35.2 \\
\hline Philippines & 20.4 & 20.4 & 19.2 \\
\hline Singapore & 74.7 & 74.7 & 74.7 \\
\hline Thailand & 15.8 & 15.8 & 15.8 \\
\hline \multicolumn{4}{|c|}{$\begin{array}{l}\text { Source: Moody's Investor Service. } \\
1 \text { / Constructed according to a numerical scale assigned to } \\
\text { Moody's weighted average bank ratings by country. " } 0 \text { " indicates } \\
\text { the lowest posible average rating and " } 100 " \text { indicates the highest } \\
\text { possible average rating. }\end{array}$} \\
\hline
\end{tabular}




\section{Prudential Regulation and Supervision}

\section{Prudential regulation and supervision continue to improve...}

16. Bank Indonesia has responded to the structural weaknesses of the banking sector by emphasizing stronger governance, internal controls, and risk management in banks. In recent years, prudential guidelines regarding corporate governance, internal controls, internal and external audit, and risk management have all been upgraded. BI's Banking Architecture Plan (Box III.2) includes many important initiatives to further improve bank operations. In this respect, BI is requiring bank commissioners, directors, and risk managers to attend formal training and pass a certification process.

\section{More generally, prudential regulations are being brought into line with the} Basel Core Principles (Box III.3). ${ }^{9}$ BI is addressing remaining gaps, such as the lack of consolidated supervision and the need for further tightening of corporate governance and related-party definitions. In addition, BI has since 2000 begun to shift the focus of supervision from compliance regulations to a risk-based framework. The new framework emphasizes identification of risks faced by institutions, and assessment of their capacity to manage those risks. BI has also established an internal Financial Stability Unit to monitor and assess overall financial stability. BI now regularly publishes a Financial Stability Review, which includes a thorough discussion of the risks facing the financial system. ${ }^{10}$ Mindful that the financial links between banks and NBFIs (e.g., with mutual funds and finance companies) are becoming closer, the Ministry of Finance is strengthening the regulatory framework of NBFIs. Specifically, regulations are being brought into line with international good practice, "fit and proper" tests for senior management instituted, minimum capital requirements put in place, and on-site examination strengthened.

18. Time and training will be required to build the experience needed to enable supervisors to fully assess the risk taking practices of financial institutions. Internal procedures will necessarily change and significant amount of investment in human capital will be required. Implementation will not only require changes in the supervisory culture but also a different response from supervised institutions. These changes will therefore be more difficult to implement than reforms in regulations, and will take time to put in place.

\section{... while a new financial sector safety net is being phased in}

19. The replacement of the blanket guarantee introduced at the time of the crisis with a financial safety net has begun (Box III.4). The first step in phasing out the blanket guarantee system was taken in April 2005, while preparations for the financial sector safety

${ }^{9} \mathrm{BI}$ 's ongoing work to improve prudential regulation and supervision is being supported by IMF technical assistance.

${ }^{10}$ See http://www.bi.go.id/web/en/Riset+Survey+Dan+Publikasi/Publikasi/. 
net are underway. The blanket guarantee will eventually be replaced by a limited deposit guarantee scheme that will cover deposits up to Rp 100 million by March 2007.

\section{Credit Growth: Determinants and Risks}

20. Credit growth is likely to remain buoyant and bank intermediation to improve, posing a challenge for banks in managing risks stemming from growing balance sheets and tougher competition. This section examines the factors underlying recent trends in bank credit, looking at both the supply and demand side, and considers the balance sheet risks that continued credit growth might entail going forward. As noted earlier, Indonesia has one of the lowest bank credit to the private sector (BCPS) ratios in the region and, loan-to-deposit and loan-to-asset ratios remain low, suggesting that banks have room to increase financial intermediation. Indeed, econometric analysis suggests that Indonesian banks are in a catching-up process, where banks with lower initial loan-todeposit ratios tend to have greater rates of credit growth (Box III.5).

\section{Credit growth has been closely related to supply-side variables, while demand variables have played a more limited role}

\section{Over the last few years, bank credit growth has been closely related to} improvements in banks' balance sheets and to an easing of supply-side constraints.

Econometric analysis indicates that over the last four years the rate of credit growth has been positively correlated with capital adequacy ratios, and negatively correlated with the net compromised asset ratios of banks. Low capitalization, in particular, has constrained credit growth, as banks with capital below prudential limits have seen their credit growth significantly limited (dummies for CAR below legal limits are significant and with negative sign). The estimated magnitude of these correlations appears significant. For example, using the basic version of our econometric model (B2), a 1 percentage point increase in the capital ratio is

\begin{tabular}{|c|c|c|c|c|c|}
\hline \multicolumn{6}{|c|}{ Indonesia. Determinants of the Growth Rate of Bank Credit } \\
\hline & \multicolumn{2}{|c|}{ Base 1/ } & \multicolumn{3}{|c|}{ Augmented } \\
\hline & B.1 & B. 2 & A.1 & A. 2 & A. 3 \\
\hline CAR (tier 1) & $\begin{array}{r}1.33^{* * * *} \\
(6.03)\end{array}$ & $\begin{array}{r}1.44 * * * \\
(7.14)\end{array}$ & $\begin{array}{r}1.48 * * * \\
(7.32)\end{array}$ & $\begin{array}{r}1.40^{* * * *} \\
(6.91)\end{array}$ & $\begin{array}{r}1.48^{* * * *} \\
(7.32)\end{array}$ \\
\hline Net compromised assets ratio & $\begin{array}{r}-0.94 * * * \\
(-2.98)\end{array}$ & $\begin{array}{r}-0.93 * * * \\
(-2.96)\end{array}$ & $\begin{array}{r}-0.65^{* *} \\
(-2.07)\end{array}$ & $\begin{array}{r}-0.73 * * \\
(-2.37)\end{array}$ & $\begin{array}{r}-0.90^{* * * *} \\
(-2.83)\end{array}$ \\
\hline Government bonds ratio & $\begin{array}{r}1.19^{* * * *} \\
(3.27)\end{array}$ & $\begin{array}{r}1.03 * * * \\
(3.44)\end{array}$ & $\begin{array}{r}1.13^{* * * *} \\
(4.21)\end{array}$ & $\begin{array}{r}1.21^{* * * *} \\
(4.39)\end{array}$ & $\begin{array}{r}0.75^{* * * *} \\
(2.49)\end{array}$ \\
\hline ROA & $\begin{array}{r}2.05 \\
(1.12)\end{array}$ & & $\begin{array}{l}\ldots \\
\ldots\end{array}$ & $\begin{array}{l}\cdots \\
\ldots\end{array}$ & $\begin{array}{l}\cdots \\
\cdots\end{array}$ \\
\hline Liquid assets ratio & $\begin{array}{r}0.24 \\
(0.57)\end{array}$ & $\begin{array}{l}\ldots \\
\ldots\end{array}$ & $\begin{array}{l}\cdots \\
\ldots\end{array}$ & $\begin{array}{l}\cdots \\
\ldots\end{array}$ & $\begin{array}{l}\cdots \\
\ldots\end{array}$ \\
\hline Firms' leverage ratio $2 /$ & & & $\begin{array}{l}-0.53^{*} \\
(-1.75)\end{array}$ & $\begin{array}{l}\cdots \\
\ldots\end{array}$ & $\begin{array}{l}\ldots \\
\ldots\end{array}$ \\
\hline Real GDP growth rate 2/ & & & & $\begin{array}{c}4.62 * * \\
(2.10)\end{array}$ & $\begin{array}{l}\ldots \\
\ldots\end{array}$ \\
\hline Lending interest rate 2 / & & & $\begin{array}{l}\ldots \\
\ldots \\
\ldots\end{array}$ & $\begin{array}{l}\ldots \\
\ldots \\
\end{array}$ & $\begin{array}{r}1.15^{*} \\
(1.78) \\
\end{array}$ \\
\hline \multicolumn{6}{|c|}{$\begin{array}{l}1 \text { Include time dummies } \\
2 \text { / The regression including this variable is not robust to the elimination of outliers and/or } \\
\text { adjustments for heteroskedascity in the error term. } \\
\text { Note. Fix effects panel regression using quarterly data } 2000-2004 \text { with one-period lagged } \\
\text { repressors. t-statistics in parenthesis. *,*, } * * * \text { denote statistical significance at the } 10 \text { percent, } \\
5 \text { percent, and } 1 \text { percent level, respectively. Dependent variable is growth rate of performing } \\
\text { bank loans. }\end{array}$} \\
\hline
\end{tabular}
associated with an increase in bank credit of about 0.7 percent, while a 1 percentage point reduction in the net compromised asset ratio corresponds to an increase in bank credit growth of about 0.4 percent. This indicates that continued progress toward better capitalization and healthier balance sheets would likely be associated with continued credit growth. At the same time, profitability and liquidity flow variables do not appear important in shaping credit dynamics. 
22. While supply-side factors have been important in explaining credit growth, credit demand has so far played a limited role. Improvements in the balance sheets of large corporations (lower leverage ratio) and increasing rate of economic growth are positively correlated with credit growth, while interest rates enter the analysis with an unexpected positive sign. However, these estimates are not robust to the elimination of outliers and homeskedistic estimates. These results seem to reflect the slow increase in bank intermediation and in the BCPS ratio observed in recent years. Thus, while supplyside factors clearly influence credit growth, the role played by credit demand has so far remained limited. However, as the economic recovery continues and credit demand from large corporations rises, demand factors are poised to play a greater role in driving credit growth.

\section{Credit and interest rate risks are considerable}

23. Although they have becoming more robust, Indonesian banks, especially state and small private banks, remain sensitive to credit and interest rate risks. An important reason behind the continued sensitivity is the large amount of restructured loans remaining on banks' books, especially of state banks. Credit risk stress tests illustrate the banks' sensitivity to a decline in asset quality. At end-2004, under a scenario which assumes that 50 percent of the loans are lost (Scenario I), banks' tier-1-to-total assets ratio declines by about 1 percentage point on average, with significant variation across banks (as indicated by the divergence between the minimum and maximum effects shown in the table). ${ }^{11}$ Out of the 15 banks under observation, 4 would have a tier-1-to-total asset ratio of less than 4 percent. Still, even if credit risks arising from the stock of restructured loans remain high, such risks are lower than in previous years. On the other hand, robust credit growth is leading to higher credit risk arising from a larger loan portfolio. In a more forward-looking scenario (Scenario II), the impact of an increase in NPLs is greater at

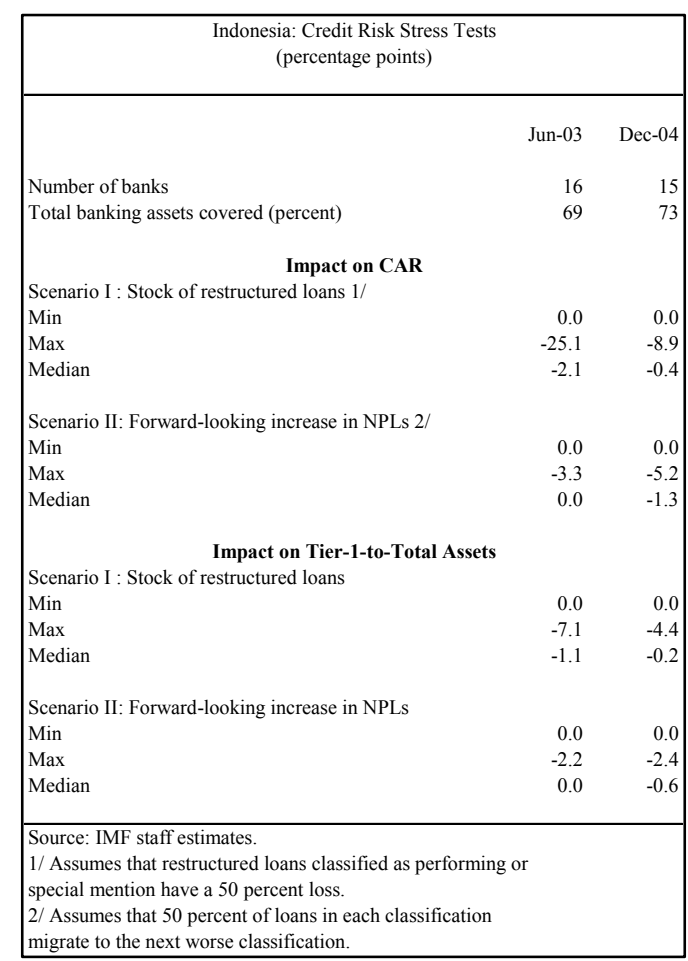
end-2004 compared to 2003 . On average, the impact was 0.6 percentage points at end-2004 compared to zero at end-2003. Interest rate risk on the banks' books-i.e., risk arising from the reprising gap between assets and liabilities - continues to be large. This reflects the

${ }^{11}$ Recognizing that CAR may overstate banks' capital adequacy, the tier-1-to-total-assets ratio is used for the stress tests. 
short-term nature of bank funding. Based on March 2005 data, a 5 percent increase in interest rates would result in a 0.7 percentage point reduction in banks' Tier 1-to-total-assets ratio. However, as with credit risk, interest rate risk on banks' books is lower than in earlier years, reflecting in part a reduction in their holdings of fixed rate recapitalization bonds.

\section{Liquidity risk is increasing while market risk is under control}

\begin{tabular}{|c|c|c|}
\hline \multicolumn{3}{|c|}{$\begin{array}{c}\text { Indonesia: Interest Rate Risk Stress Tests } \\
\text { (percentage points) }\end{array}$} \\
\hline & Mar-02 & Mar-05 \\
\hline Number of banks $1 /$ & 16 & 15 \\
\hline Total banking assets covered (percent) & 69 & 73 \\
\hline \multicolumn{3}{|l|}{ Impact on CAR } \\
\hline Scenario I : 5 percent increase in interest rates 2 / & -2.8 & -1.2 \\
\hline Scenario II: 10 percent increase in interest rates $2 /$ & -5.7 & -2.5 \\
\hline \multicolumn{3}{|c|}{ Impact on Tier-1-to-Total Assets } \\
\hline Scenario I : 5 percent increase in interest rates $2 /$ & -1.3 & -0.7 \\
\hline Scenario II: 10 percent increase in interest rates 2 / & -2.7 & -1.4 \\
\hline \multicolumn{3}{|c|}{$\begin{array}{l}\text { Source: IMF staff estimates } \\
1 \text { Tests done on an aggregate basis. } \\
2 \text { / The interest rate stress tests on the banking book were calculated } \\
\text { as the impact of an interest rate increase on the cumulative gap up to } \\
12 \text { months. }\end{array}$} \\
\hline
\end{tabular}

\section{While aggregate liquidity is high-albeit declining in tandem with the loan} growth - it is not evenly distributed and the interbank market remains segmented. Even among large banks, liquidity can differ substantially, with 4 banks having a liquid asset-to-total asset ratio below 10 percent. In addition, the planned transfer of government deposits from commercial banks to BI, in the context of treasury reforms, and the phasing out of the blanket guarantee could create pressures on banks. ${ }^{12}$
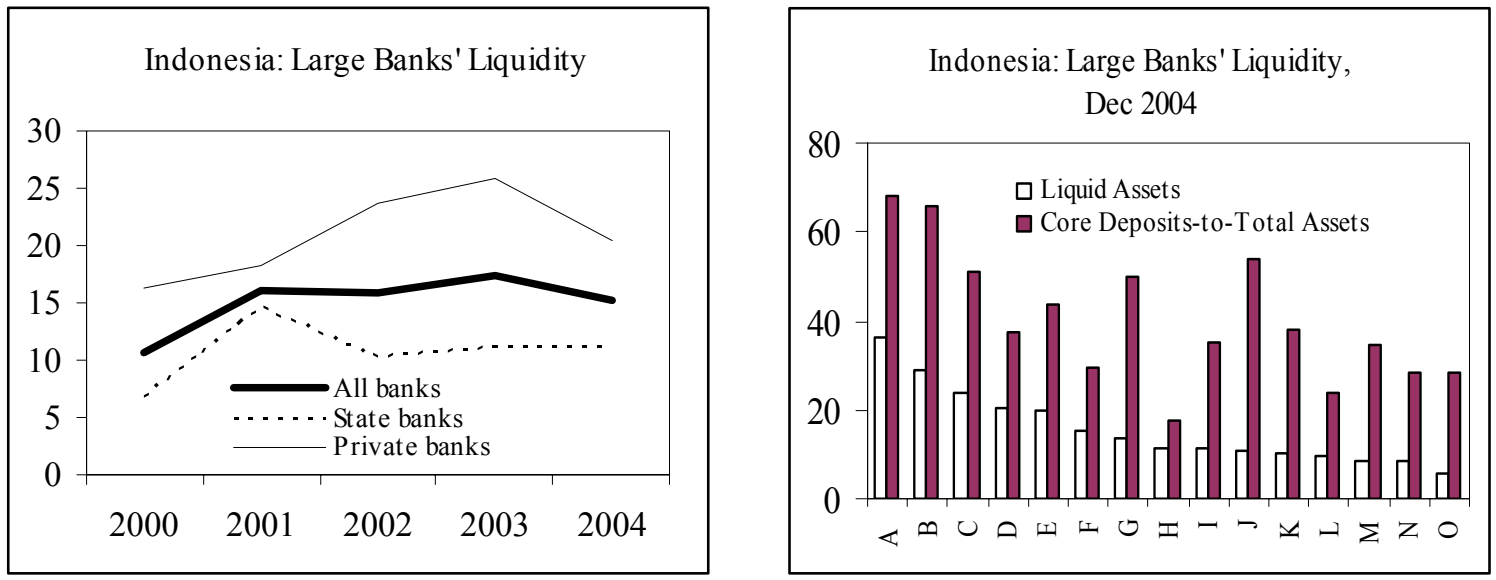

\section{On the other hand, most banks have been conservative in taking on market}

risk. BI's stress testing indicates that, on average, banks' capital adequacy ratios are barely affected by moderate movements in the exchange or interest rate. These tests assume (i) a

\footnotetext{
${ }^{12} \mathrm{BI}$ 's stress testing indicates that the planned transfer of government deposits from commercial banks to $\mathrm{BI}$ in the context of treasury reforms could create problems for large banks, especially if the transfer was done over a short period of time. In addition, there is potential for pressures on smaller banks if there is a flight to quality during the removal of the blanket guarantee.
} 
2500 point depreciation in the Rupiah versus the U.S. dollar, (ii) a 100 bps increase in interest rate, and (iii) a $100 \mathrm{bps}$ decrease in interest rate. For all scenarios, the banks' capital adequacy remains well above the minimum requirement. On average, the system's CAR is hardly changed: it remains at about 19 percent before and after these scenarios. For individual banks, the most extreme adverse shock reduces CAR by less than 1 percent. ${ }^{13}$

\section{E. Conclusions: Outlook and Policy Issues}

26. Banks are well placed to continue expanding their lending, but will need to manage associated risks carefully. High CARs and low compromised assets mean that banks' future credit capacity is not unduly constrained, while continued economic growth would likely foster demand for credit. The challenge will be to manage the balance sheet risks arising from lending growth, particularly credit and liquidity risks. These risks have to be managed in an environment where governance, informational, and legal frameworks are weak. This will be particularly challenging as competition is likely to increase in consumer and SME lending, where banks have been concentrating their growth, thus reducing spreads and leading to more normal profitability. Declining profitability, together with BI's consolidation strategy, will likely lead to greater consolidation of the banking system.

\section{In order to ensure sound credit growth expansion in support of economic} growth while controlling risks, the authorities are focused on a number of key policy issues:

- $\quad$ Preserving banks' asset quality. This will be critical to support continued credit growth and limit risks associated with an expanding portfolio, particularly in large state banks with less strong financial positions and governance.

- $\quad$ Addressing governance vulnerabilities, including at large state banks. State banks should be run on a commercial basis, and their internal governance and risk management processes improved. In this respect, every effort is needed to ensure that any bank lending to support infrastructure projects is commercially viable. Further private sector participation in state banks may help improve governance and performance of these banks.

- $\quad$ Continuing to improve prudential regulation and supervision of all financial institutions. This would entail addressing gaps such as the lack of banks' consolidated supervision, managing the transition to a risk-based supervisory framework, and continuing to improve implementation of existing regulations. The ongoing work to strengthen supervision of pension funds, and mutual funds,

\footnotetext{
${ }^{13}$ See latest Financial Stability review at http://www.bi.go.id/web/en/Riset+Survey+Dan+Publikasi/Publikasi/.
} 
insurance companies and finance companies is also important, especially as their links with the banking sector are growing in importance.

- Ensuring a smooth transition from the blanket guarantee scheme to the new limited deposit insurance scheme. This will require having the new scheme operational before the full removal of the blanket guarantee. A number of measures are underway to this end.

- Implementing BI's banking architecture plan consistently over time. The plan has many elements that would create a sounder banking system. In particular, steps to address structural weaknesses in banks' governance as well as informational infrastructure are important. The push for bank consolidation is also welcome, and should be market-led. 


\section{Box III.1. Corporate Governance and Risk Management in Banks}

Banks have taken steps to improve corporate governance although further efforts are needed to introduce international good practices in key areas. ${ }^{1}$ Recent improvements include steps to increase the independence and quality of Board members, especially for large private banks with strategic foreign investors. Many banks have established audit and risk committees to oversee major risks. Transparency has also been increased with the publication regular and more extensive data, and the participation of investors in both private and state banks. However, gaps remain in areas such as (i) setting and communicating strategic directives, (ii) establishing clear lines of responsibility and accountability, (iii) clarifying the roles of shareholders, management, and other stakeholders, (iv) appointing qualified bank commissioners and directors, (v) empowering commissioners to carry out their supervisory functions effectively, and (vi) making effective use of internal and external audit.

Risk management capacity in large banks has also been upgraded. These upgrades include: (i) introducing policies and procedures on risk management and oversight (ii) establishing centralized risk management functions, (ii) creating specialized functions to cover major risks such as credit, market, and operational risks, (iii) building databases and models to appropriately measure risk, and (iv) separating business and risk management functions ("four eyes principle"). The larger banks are also making efforts to comply with Basel II by 2008 .

Although policies and procedures to ensure good risk management appear to be in place, there are still questions concerning effective implementation. Staff competence, policy adherence and management commitment could be further strengthened in some banks. Indeed, some banks face high operational risks because of weaknesses in policy adherence and a culture that tolerates exceptions. Furthermore, sophisticated technology needs to be adapted to local circumstances and integrated into day-to-day operations, MIS and IT challenges are also non-trivial. Most important, good practices in risk management require a change in thinking and the way business is done; this necessarily takes time and requires significant investment in human capital.

${ }^{1}$ Conclusions are based on discussions with banks, supervisors, and banks' annual disclosures. International good practices comprise the Basel Committee on Banking Supervision guidelines on good corporate governance as well as the OECD Principles on Corporate Governance. 


\section{Box III.2. The Banking Architecture Plan}

In 2004, Bank Indonesia released the Banking Architecture Plan, a blueprint for creating a sounder and more efficient banking system. ${ }^{1}$ The API is a long-term plan (1015 years) containing the vision of an optimum banking landscape, and a series of initiatives to improve banking sector performance. The API is built on six pillars, focused on: (i) banking sector structure, (ii) quality and effectiveness of banking regulations, (iii) banking supervision, (iv) quality of bank management operations, and corporate governance, (v) infrastructure to support the banking sector, and (vi) consumer protection.

As a part of the API, the central bank is about to launch a program to increase banks' capital and foster greater consolidation in the sector. The API envisages a gradual move in the next 10-15 years towards a banking system where 2-3 banks emerge as international banks with large capitalization, 3-5 banks as smaller national banks, and 30-50 smaller banks as niche banks. In this context, banks with limited capital (below Rp 100 billion) would be restricted in their activities or downgraded to rural credit banks. The central bank is expected to announce criteria for "well-run" banks soon and these banks are expected to be the nucleus for the consolidation process.

${ }^{1}$ See www.bi.go.id/web/en/Info + Penting/Arsitektur+Perbankan+BI/ 


\section{Box III.3. Prudential Regulation and Supervision}

Enhancements to banking regulation and supervision, recently implemented or underway:

- Introduction of tighter asset classification rules, including a requirement that banks follow BI's assessments, if there is a difference between banks and BI's credit assessment.

- $\quad$ Development of guidelines to introduce consolidated supervision, including steps to identify banking groups, produce consolidated reports, and apply prudential norms on a consolidated basis.

- Development of a more comprehensive definition of related parties.

- $\quad$ Reassessment of guidelines on corporate governance in banks.

- Introduction of risk-based supervision.

- $\quad$ Preparations for Basel II.

- Implementation of a risk-based capital charge for market risk.

- $\quad$ Strengthening compliance with AML/CFT requirements, such as upgrading examination procedures and bank examiners' skills.

Enhancements to NBFI regulation and supervision, recently implemented or underway:

- $\quad$ Harmonization of insurance regulations with International Association of Insurance Supervisor (IAIS) principles, and introduction of risk-based and minimum capital requirements.

- Introduction of requirement for more timely and complete provision of information.

- Introduction of "fit and proper" tests for senior managements of insurance and finance companies; introduction of certification requirements for insurance agents and pension fund administrators.

- $\quad$ Strengthening of on-site examination of NBFIs and closure of several small insolvent insurance companies. 


\section{Box III.4. Financial Safety Net and Deposit Insurance Scheme}

The authorities have developed a framework for a financial safety net (FSN). The financial safety net aims at: (1) preventing weaknesses in financial institutions and instability in financial markets; (2) identifying and addressing financial weaknesses and instability; and (3) minimizing the costs of these weaknesses and instability.

The financial safety net has three pillars:

- A deposit insurance scheme, that would eventually guarantee deposits up to Rp 100 million (currently covering about 90 percent of all depositors);

- A lender of last resort facility at the central bank, that would provide intra-day and short-term liquidity support and, in case of systemic risk, emergency liquidity assistance to solvent banks;

- A framework for bank resolution, defining the role and ensuring institutional coordination among various government agencies during a financial crisis, through a coordinating committee and financial stability forum.

As part of the introduction of the FSN, the government has started phasing out the blanket guarantee and plans its full removal in 2005. In April, the government started limiting the blanket guarantee to saving deposits and interbank loans (through the inter-bank money market). Moreover, for an interim period, the responsibility for administering the blanket guarantee has been transferred to the MoF. On September 22, 2005, the deposit insurance agency (LPS) is slated to become operational and a limited deposit insurance will substitute for the blanket guarantee. In the first six months following the establishment of LPS, the full value of eligible deposits would be insured. In the second six-month period, deposits up to a maximum of Rp 5 billion would be insured; in the third six-month period, this amount would fall to Rp 1 billion; and from March 22, 2007 onward, only deposits up to Rp 100 million would be covered.

The authorities are taking several steps to establish the financial safety net. These include completing the operational arrangements for the deposit insurance agency, and issuing BI regulations and government decrees on emergency lending assistance and the financial stability forum, as well as approving the financial safety net law that would put the safety net framework on firm legal grounds. 


\section{Box III.5. Empirical Analysis of Bank Credit Growth}

We estimate an econometric model of how the quality of bank portfolios and factors potentially influencing credit demand link to bank credit growth in Indonesia. The basic model regresses the growth rate of performing bank loans on lagged summary measures of bank asset quality (e.g., net compromised asset to loans ratio, $N C A / L$; capital adequacy ratio-tier $1, C A R$; and government bonds to assets ratio $G O V B / A$ ), profitability (return on asset ratio, $R O A$ ), and liquidity (liquid assets ratio, LA/A). This model is then augmented to include factors that may influence bank credit demand such as lagged leverage ratios of corporations, and macroeconomic variables such as lagged interest rates and GDP growth rates. The augmented specification intended to capture supply-side constraints, as well as trends in factors that may hinge on credit demand. The non-augmented basic model takes the following form:

$g_{L_{i t}}=\alpha+\beta_{1} C A R_{i t-1}+\beta_{2} N C A_{i t-1} / L_{i t-1}+\beta_{3} G O V B_{i t-1} / A_{i t-1}+\beta_{4} R O A_{i t-1}+\beta_{5} L A_{i t-1} / A_{i t-1}+\varepsilon_{i t}$

where $i=$ bank, $t=$ time, and $g_{L}$ denotes the growth rate of performing loans. In this model, unobservable bank-level variables are controlled for by using fix effects.

Data include a quarterly panel of the $\mathbf{1 6}$ major Indonesian banks (about 80 percent of total system-wide assets) over the period 2000-2004 (272 observations), quarterly aggregate leverage ratios of corporations listed on the Jakarta stock exchange, and quarterly economic variables, including lending interest rates and de-seasonalized real GDP growth rates.

The model suggests that bank credit growth in Indonesia has been closely related to supplyside variables, while the role played by credit demand has so far been limited. Specifically, bank credit growth is positively correlated to capital adequacy ratios, and negatively correlated to the net compromised ratios of banks, while profitability and liquidity flows variables do not appear significant. Contrary to one may expect, in recent years, banks' holding of government bonds have been positively associated with future credit growth, indicating that banks with large stock of bonds are set to have higher credit growth rate in the future. Finally, the role played by factors associated with credit demand, such as corporations' balance sheets and macroeconomic conditions, including economic growth and interest rates appears to have been limited. The lending behavior of stateowned banks does not differ substantially from that of private banks (ownership dummies make no difference to the results). These results are rather stable, and robust to alternative model specifications and random effects estimates. They are robust to heteroskedasticity, and correlated disturbances (AR-1 disturbances). Moreover, results remain similar (but less significant) when annual data are considered.

These results should not be seen as reflecting causality links, rather, they identify correlations between credit growth and a set of bank balance sheet indicators and variables that potentially affects demand for credit. Furthermore, the period under study is one that has seen great structural changes, which means that it may not be a good predictor of developments during normal times. 
Figure 1. Indonesia: Financial Soundness Indicators for Large Banks, 2000-2004

Nonperforming loans continue to decline...

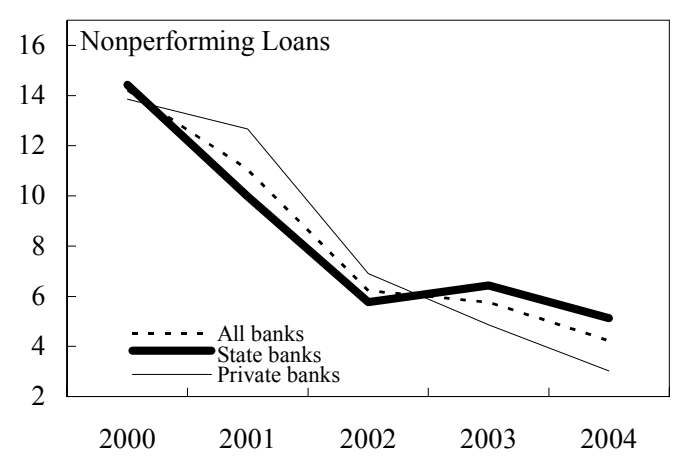

Profitability is high...

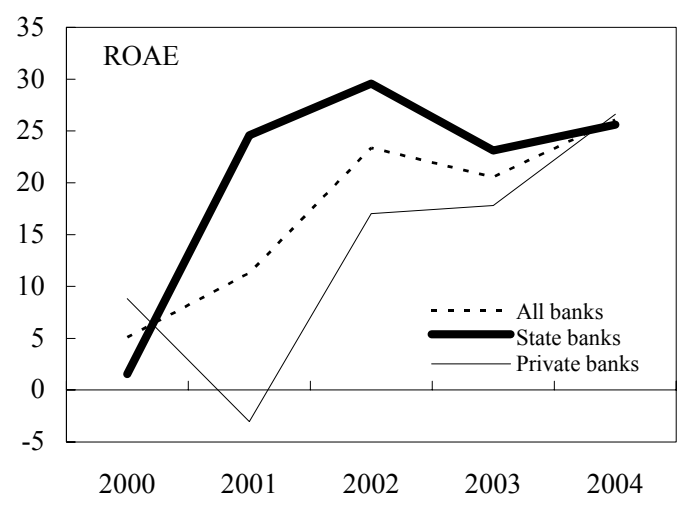

Banks' CAR is also high...

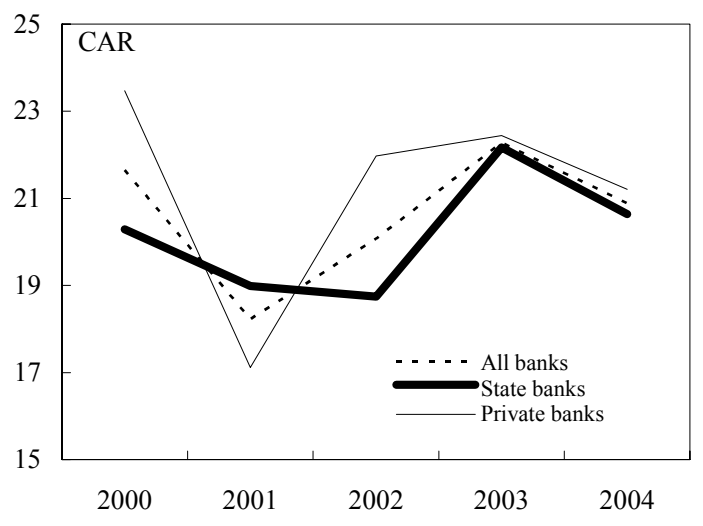

...though compromised assets remain high.

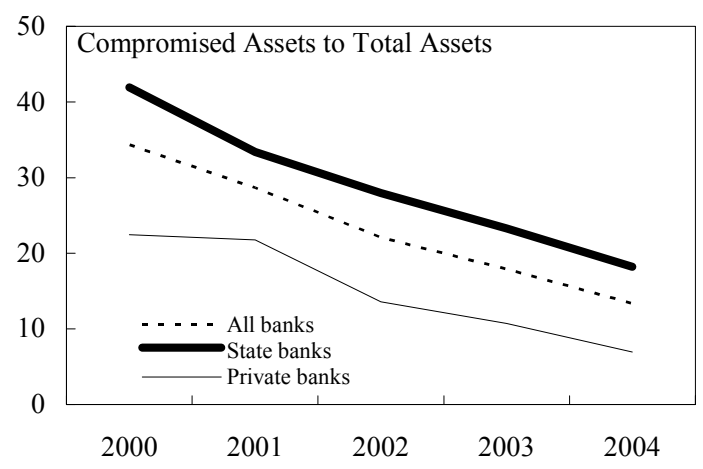

...reflecting high margins.

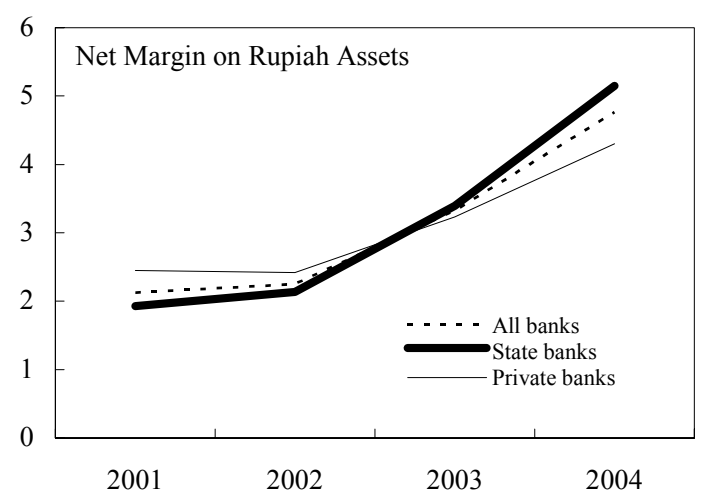

... and capital rebuilding continues.

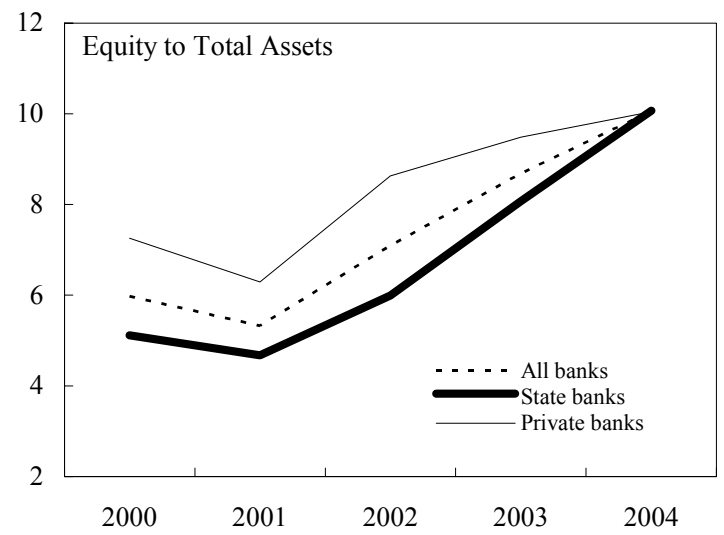

Source: Bank Indonesia. 
Figure 2. Indonesian Banks in the ASEAN Context

Indonesian banks have one of the highest CAR... ...although more modest equity/assets.

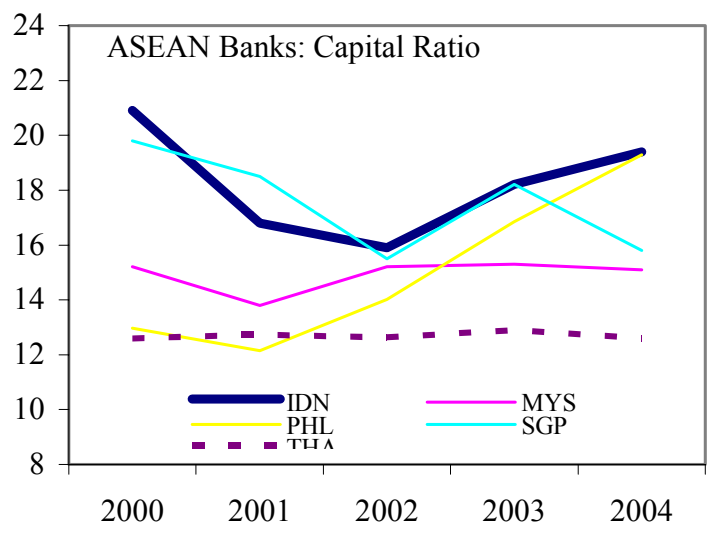

They also have one of the highest ROAA...

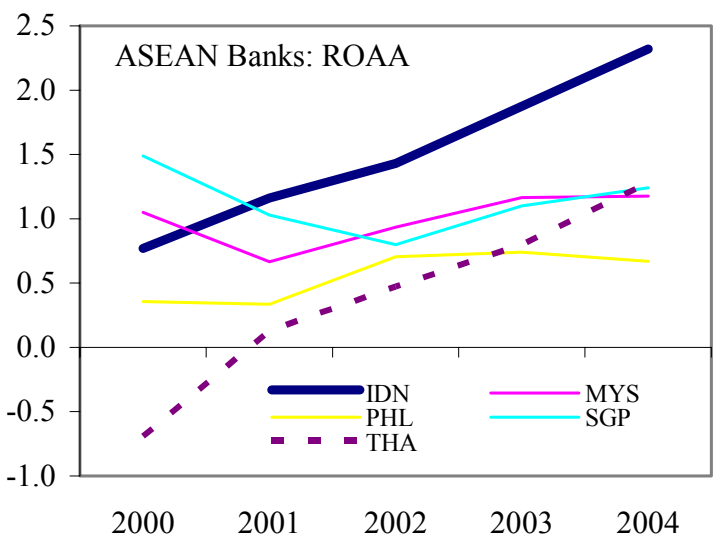

...on the back of very high net interest margins...

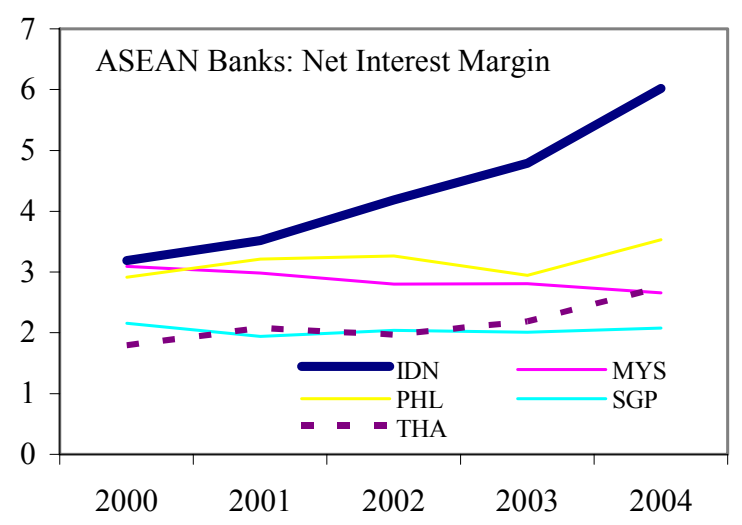

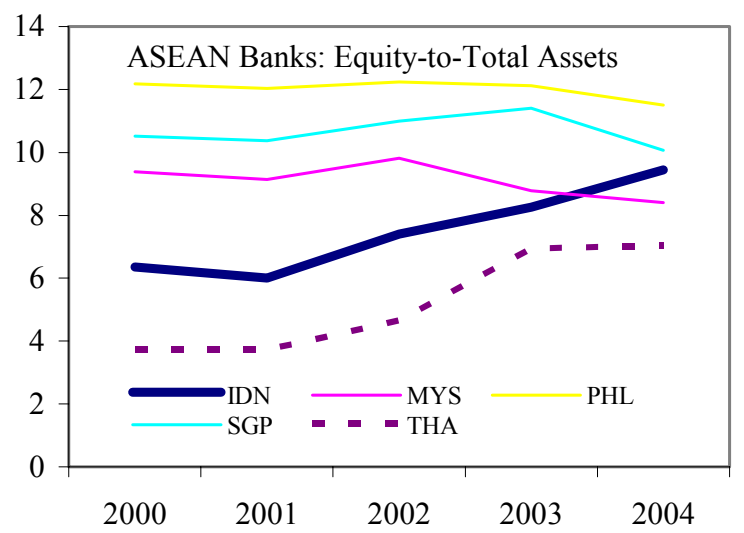

...and ROAE

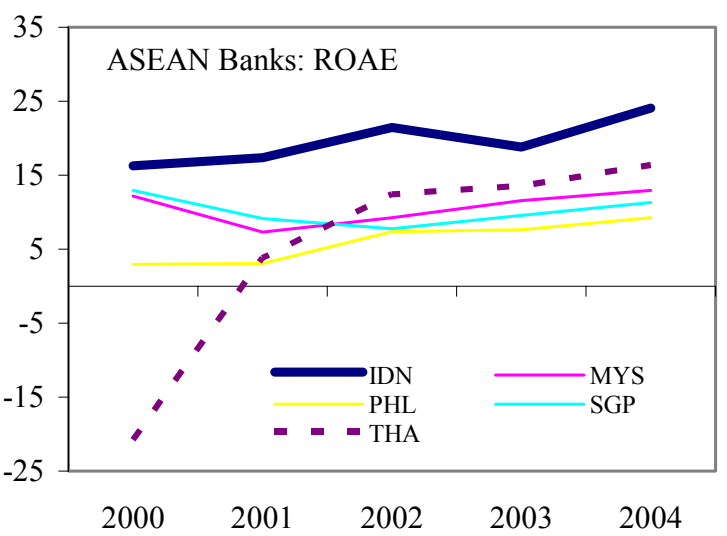

... and modest costs.

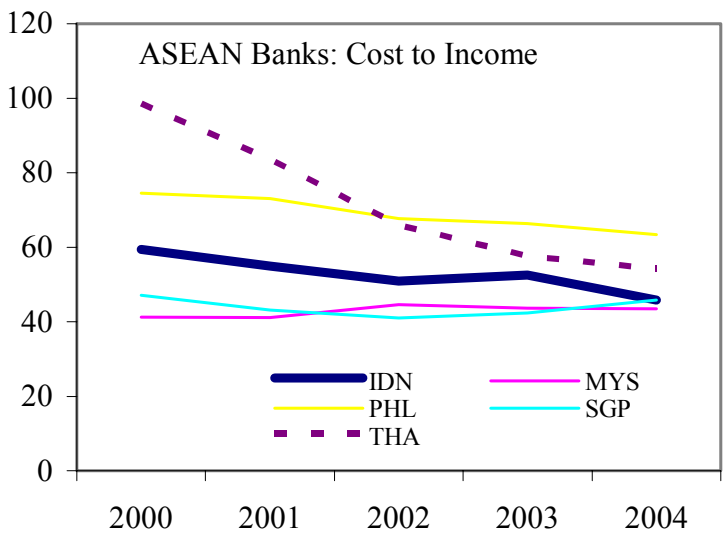

Source: Bankscope 
Figure 2 (concluded). Indonesian Banks in the ASEAN Context

Indonesian banks have strong interest earnings...

... and modest other income

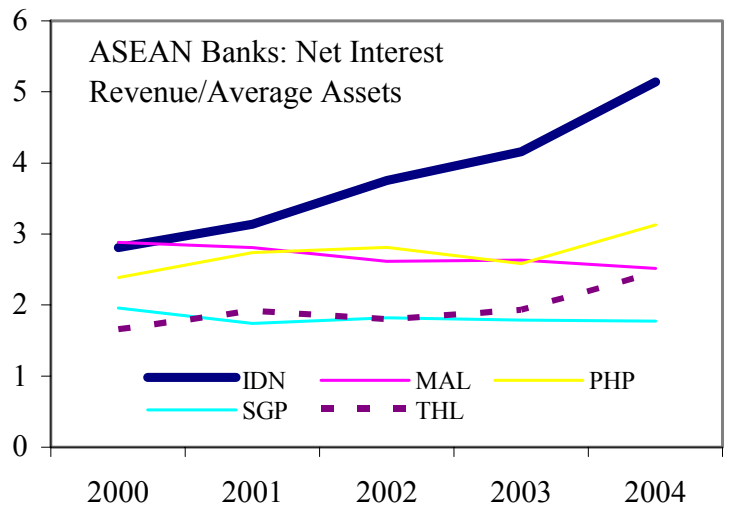

They have declining impaired loans...

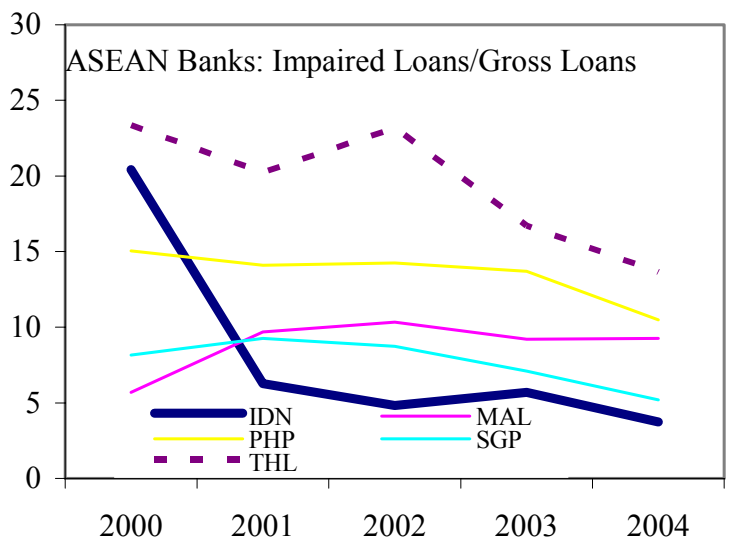

Their loans are still a small share of total assets..

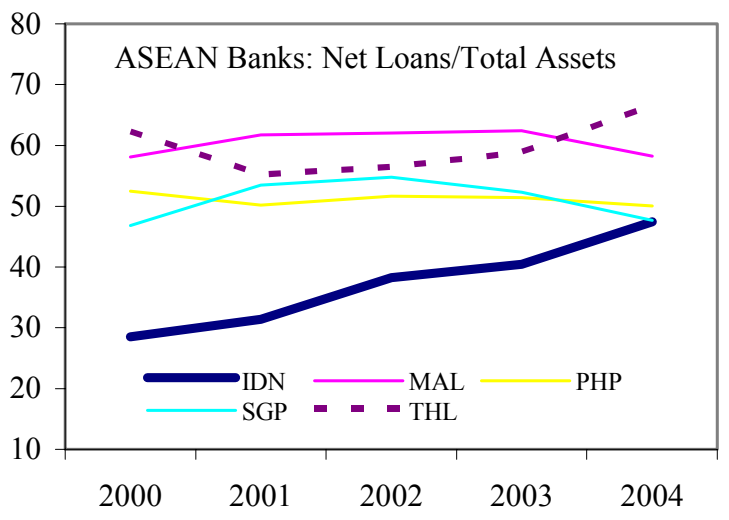

Source: Bankscope

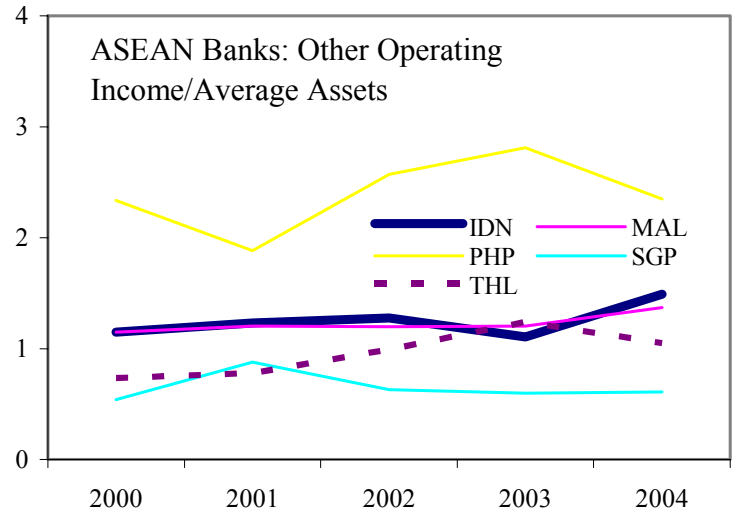

...and lower provisioning

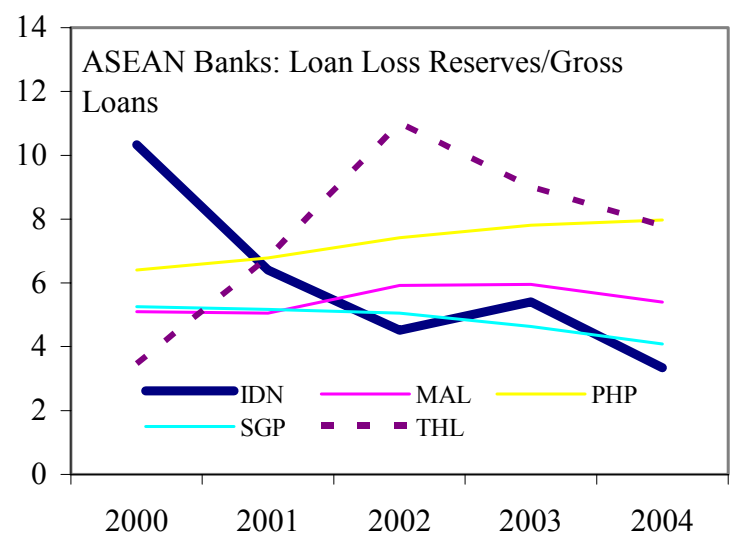

... and their level of liquidity is modest.

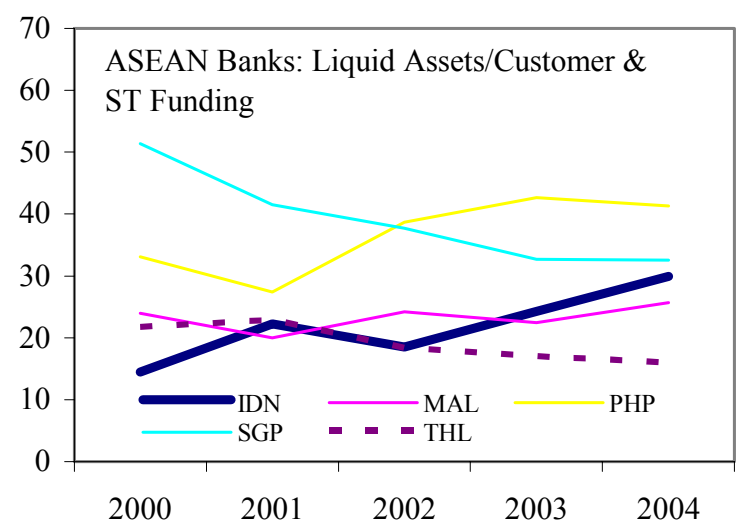


Figure 3. Indonesia: Distance-to-Default Measures for Large Banks, 2000-2004

BANK BUANAINDONESA

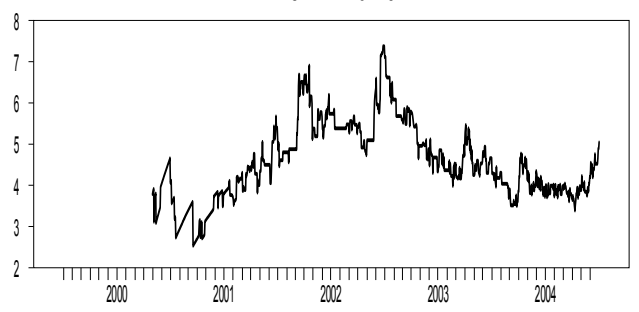

BANKCENTRAL ASIA

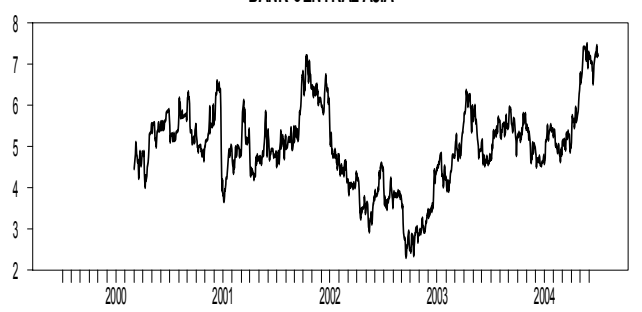

BANK DANAMON INDONESIA

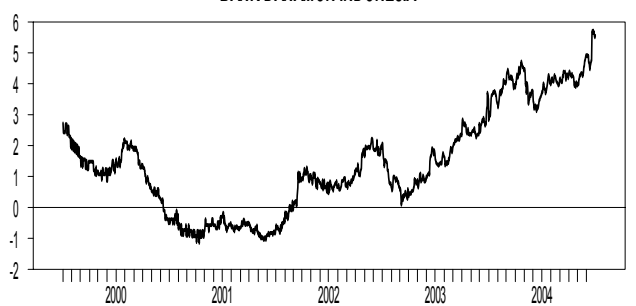

BANKINTLINDONESSAB||

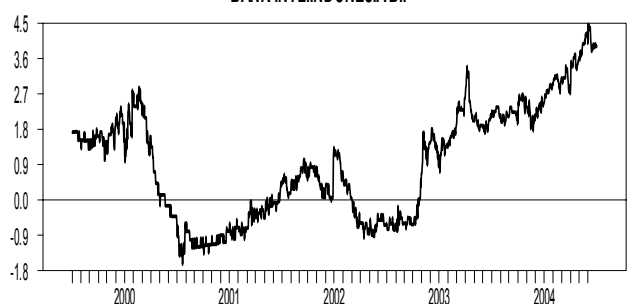

BANKMANDIR

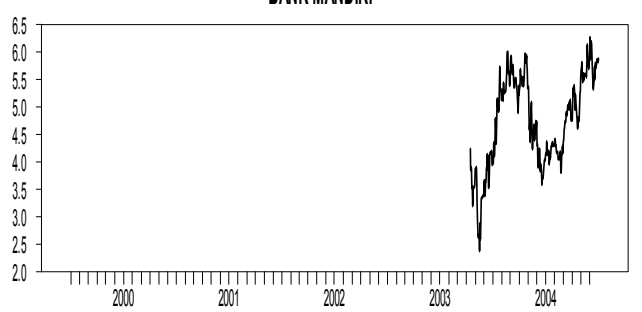

BANKMEGA

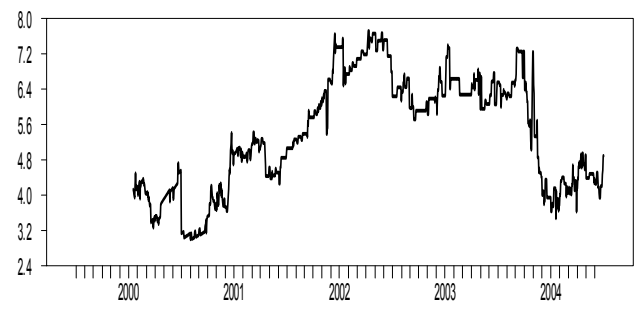

BANK NEGARA INDONESIA

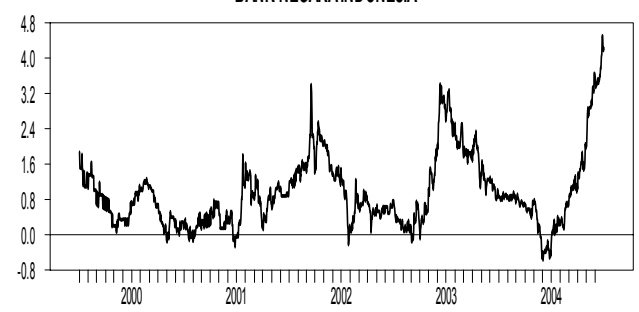

BANKNIAGA

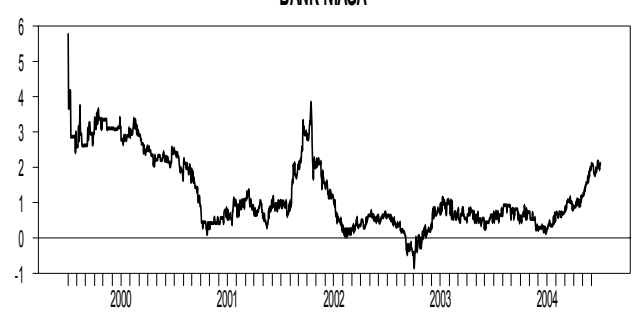

BANK RAKYAT INDONESIA

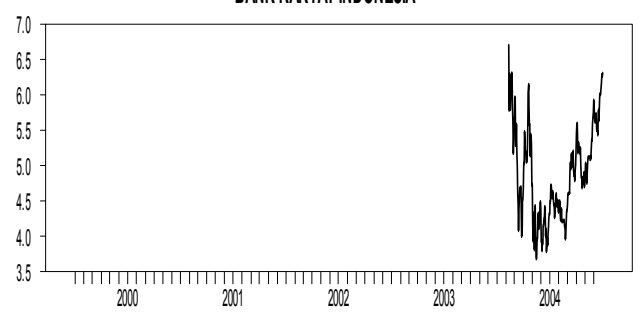

LIPPOBANK

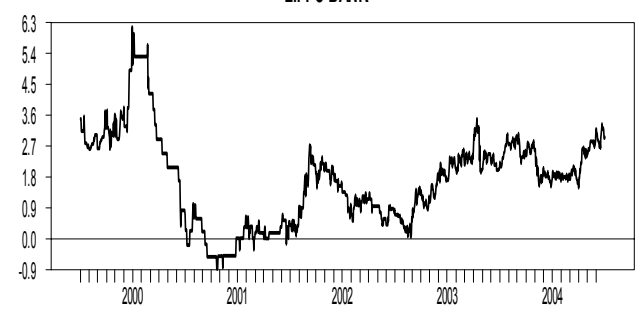

Source: IMF staff calculations. 
Table 1. Indonesia: Financial System Structure, 2000-2004

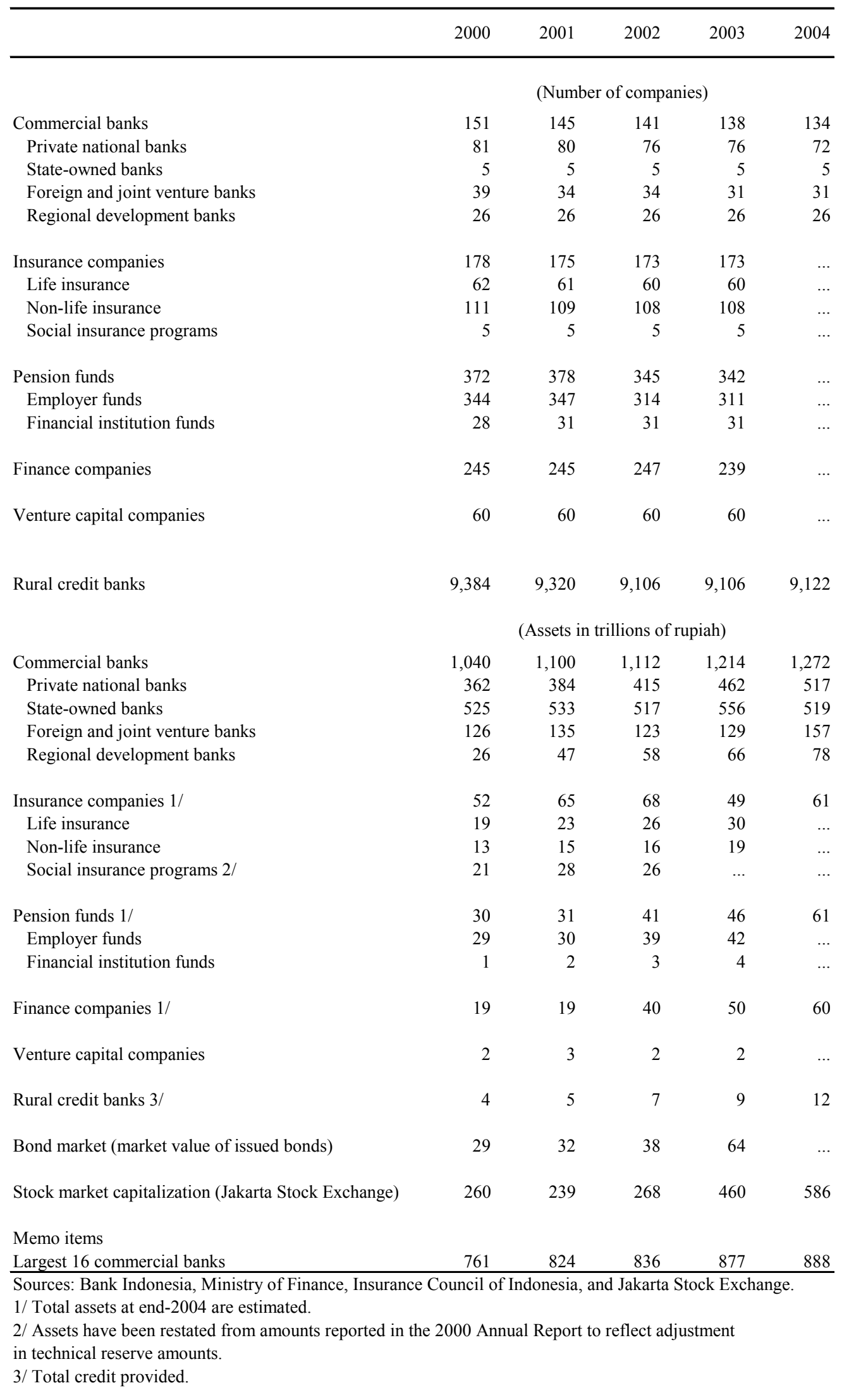


Table 2. Indonesia: Financial Soundness Indicators of Large Banks, 2000-2004

\begin{tabular}{|c|c|c|c|c|c|}
\hline & 2000 & 2001 & 2002 & 2003 & 2004 \\
\hline \multicolumn{6}{|l|}{ I. Asset Structure } \\
\hline \multicolumn{6}{|l|}{ YTD loan growth } \\
\hline All banks & $\ldots$ & 14.1 & 25.0 & 20.6 & 26.2 \\
\hline State banks & $\ldots$ & 14.9 & 22.4 & 17.8 & 24.4 \\
\hline Private banks & $\ldots$ & 13.0 & 29.0 & 24.6 & 28.6 \\
\hline \multicolumn{6}{|l|}{ II. Asset Quality } \\
\hline \multicolumn{6}{|l|}{ NPL/total loans } \\
\hline All banks & 14.2 & 11.0 & 6.2 & 5.8 & 4.2 \\
\hline State banks & 14.4 & 10.0 & 5.8 & 6.4 & 5.1 \\
\hline Private banks & 13.9 & 12.7 & 6.9 & 4.9 & 3.0 \\
\hline \multicolumn{6}{|c|}{ Compromised assets } \\
\hline All banks & 34.4 & 28.6 & 22.1 & 17.9 & 13.4 \\
\hline State banks & 41.9 & 33.4 & 28.0 & 23.3 & 18.2 \\
\hline Private banks & 22.4 & 21.7 & 13.6 & 10.7 & 7.0 \\
\hline \multicolumn{6}{|l|}{ III. Liquidity } \\
\hline \multicolumn{6}{|c|}{ Liquid assets/total assets } \\
\hline All banks & 10.7 & 16.1 & 15.9 & 17.4 & 15.3 \\
\hline State banks & 6.8 & 14.5 & 10.3 & 11.1 & 11.1 \\
\hline Private banks & 16.4 & 18.3 & 23.6 & 25.8 & 20.5 \\
\hline \multicolumn{6}{|l|}{ IV. Earnings } \\
\hline \multicolumn{6}{|c|}{ Core earnings-to-average assets } \\
\hline All banks & 0.8 & 1.7 & 1.8 & 2.5 & 3.1 \\
\hline State banks & 0.4 & 1.8 & 1.9 & 2.4 & 3.3 \\
\hline Private banks & 0.4 & 1.6 & 1.6 & 2.5 & 2.9 \\
\hline \multicolumn{6}{|c|}{ After tax net income-to-average assets (ROAA) } \\
\hline All banks & 0.5 & 0.6 & 1.3 & 1.7 & 2.6 \\
\hline State banks & 0.1 & 1.2 & 1.6 & 1.7 & 2.5 \\
\hline Private banks & 0.5 & -0.2 & 1.0 & 1.6 & 2.7 \\
\hline \multicolumn{6}{|c|}{ Net income-to-average equity } \\
\hline All banks & 5.1 & 11.3 & 23.4 & 20.5 & 26.1 \\
\hline State banks & 1.5 & 24.6 & 29.6 & 23.1 & 25.6 \\
\hline Private banks & 8.8 & -3.0 & 17.0 & 17.8 & 26.6 \\
\hline \multicolumn{6}{|l|}{ V. Capital } \\
\hline \multicolumn{6}{|c|}{ Capital adequacy ratio (CAR) } \\
\hline All banks & 21.6 & 18.2 & 20.1 & 22.3 & 20.9 \\
\hline State banks & 20.3 & 19.0 & 18.7 & 22.2 & 20.6 \\
\hline Private banks & 23.5 & 17.1 & 22.0 & 22.4 & 21.2 \\
\hline \multicolumn{6}{|c|}{ Tier-1 capital/total assets } \\
\hline All banks & 3.8 & 3.6 & 5.2 & 6.8 & 8.1 \\
\hline State banks & 3.2 & 3.5 & 4.6 & 6.7 & 8.3 \\
\hline Private banks & 4.6 & 3.7 & 6.1 & 7.0 & 8.0 \\
\hline
\end{tabular}

Source: Bank Indonesia. 


\section{References}

Cole and Slade (1998), "Why has Indonesia's Financial Crisis Been so Bad," Bulletin of Indonesian Economic Studies, Vol. 34, August, pp.61-66.

Enoch C, Balwin B, Frecaut, O. and Kovanen A (2001), "Indonesia : Anatomy of a Banking Crisis: Two Years of Living Dangerously, 1997-99," IMF Working paper 01/52, International Monetary Fund, Washington DC.

Pangestu M. and Habir M. (2002), "The Boom, Bust, and Restructuring of Indonesian Banks," IMF Working paper 02/66, International Monetary Fund, Washington DC.

Seelig, Steven et al. (2004), “Assessing Indonesia's Banking Sector Reforms,” Indonesia: IMF Country Report 04/189.

Bank Indonesia (2004), Financial Stability Reviews. 


\section{INDONESIA'S EXTERNAL COMPETITIVENESS: AN UPDATE ${ }^{1}$}

1. This chapter provides an assessment of the external competitiveness of Indonesia based on a range of real exchange rate measures and on export performance. A country's competitiveness has important implications for trade performance and overall growth. External competitiveness can be defined as "the degree to which a country can, under free trade and fair market conditions, produce goods and services which meet the test of international markets, while simultaneously maintaining and expanding the real incomes of its people over the long term."2

\section{A. Real Effective Exchange Rate Indicators}

2. A variety of real effective exchange rate indicators suggest a steady decline in external competitiveness since the immediate aftermath of the crisis, with some improvement since 2003. This is the case for REER indices based on the consumer price index (CPI), the wholesale price index (WPI), and unit labor costs (ULC). ${ }^{3}$

\section{Indicators of the internal} real exchange rate suggest a steady loss of competitiveness of the traded goods sector from immediately after the crisis to mid-2000, followed by modest improvements recently. The internal real exchange rate

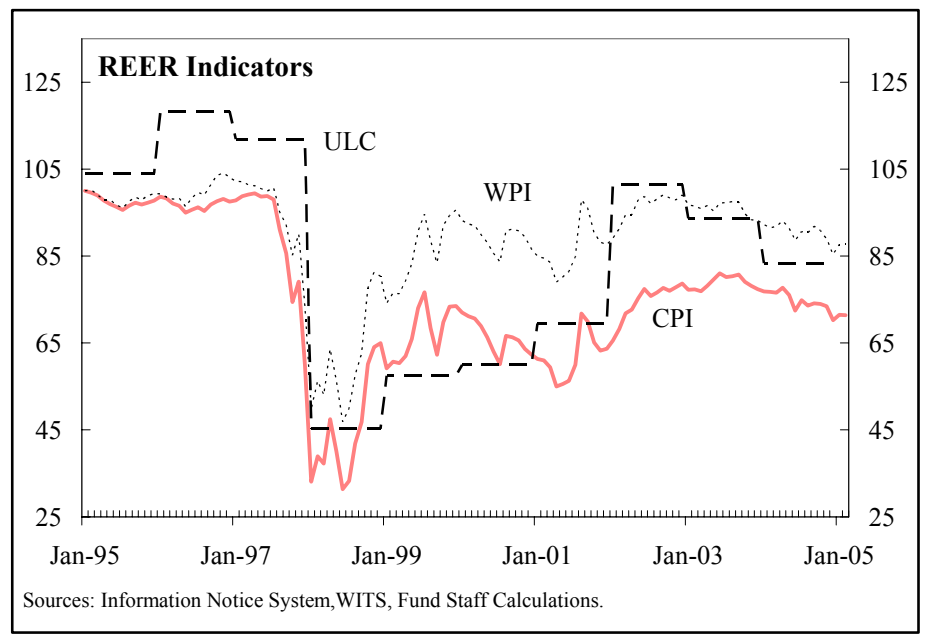
measures the relative price of nontradable goods to tradable goods, and is an indicator of the relative attractiveness of production in the nontraded goods sector. ${ }^{4}$ The prices received

${ }^{1}$ Prepared by Matthew Jones (PDR). This chapter updates the assessment of Indonesia's competitiveness presented in the 2004 Selected Issues paper (Chapter VI of IMF Country Report No. 04/189).

${ }^{2}$ OECD (1992), page 237.

${ }^{3}$ The weights are export based and represent a recalculation of comparator countries using 2003 data, similar to Zanello and Desruelle (1997) and Bayoumi, Lee, and Jayanthi (2005). For a review of the literature and for a discussion of the advantages and disadvantages of different price deflators, see Hinkle and Montiel (1999). See Turner and Golub (1997) for details of calculating ULC measures.

${ }^{4}$ See Hinkle and Montiel (1999) for a discussion of the concepts. IRER1 is calculated using the CPI divided by the GDP deflator for imports. IRER 2 is calculated by dividing the 
by firms operating in the nontraded goods sector have increased relative to the traded sector, implying that the relative returns to investing in the traded goods sector have declined since the immediate aftermath of the crisis. The indicators remain well below their pre-crisis levels, however. An analysis of export profitability, using the ratio of export prices to manufacturing wages as a proxy for profitability, shows a steady decline in competitiveness after the initial boost following the crisis. Indeed, the indicator suggests that the post-crisis gains in profitability have been largely erased by the steady increase in labor costs over the subsequent period.
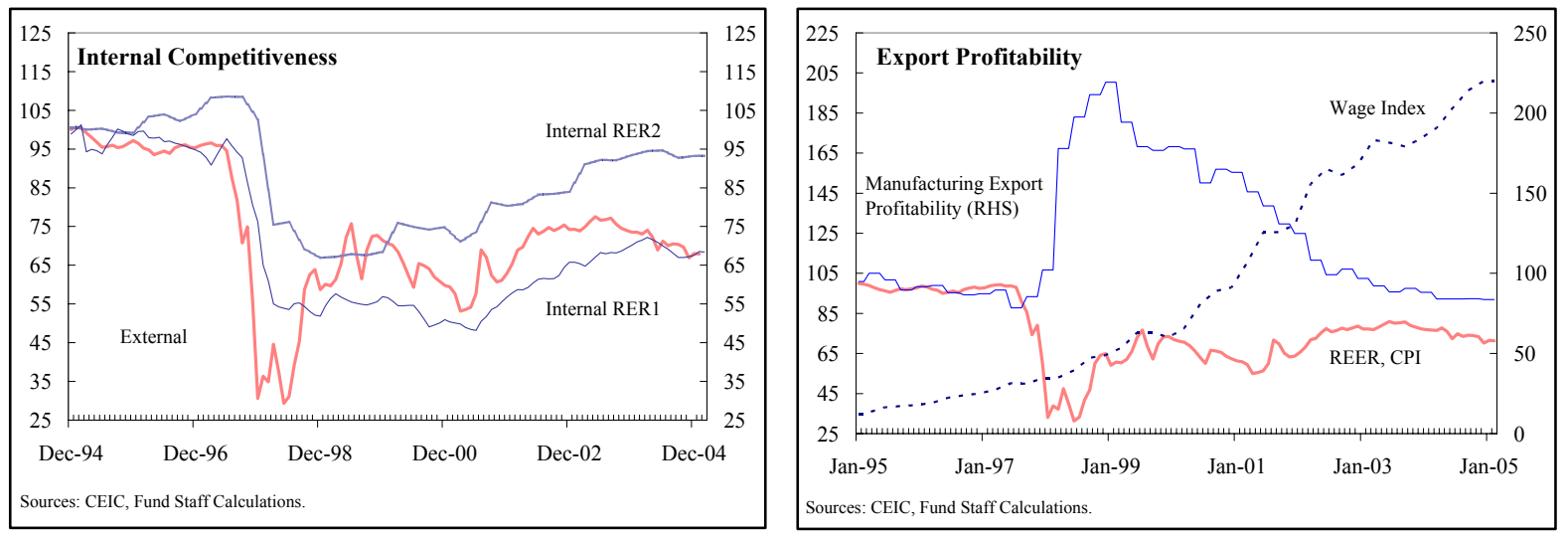

\section{B. Export performance}

\section{Indonesia's export performance has not kept pace with that of its neighbors}

since the crisis. Indonesia's relative export performance has weakened since 2000, particularly when compared with other countries in emerging Asia: ${ }^{5}$

- Indonesia has lost export market shares. Underlying Indonesia's overall loss of export market shares are losses in market shares in major trading partners, with the market share declining since 1999 in five of its six largest export destinations (Malaysia being the exception), and in its 15 largest export markets.

difference between the GDP deflator and an export price deflator with an import price deflator.

${ }^{5}$ Emerging Asia consists of Bangladesh, Bhutan, Brunei Darussalam, Myanmar, Cambodia, China, Sri Lanka, Indonesia, Taiwan Province of China, Hong Kong SAR, India, Korea, Lao People's Democratic Republic, Macao, Malaysia, Maldives, Nepal, Palau, Philippines, Singapore, Thailand, Timor-Leste, and Vietnam. 

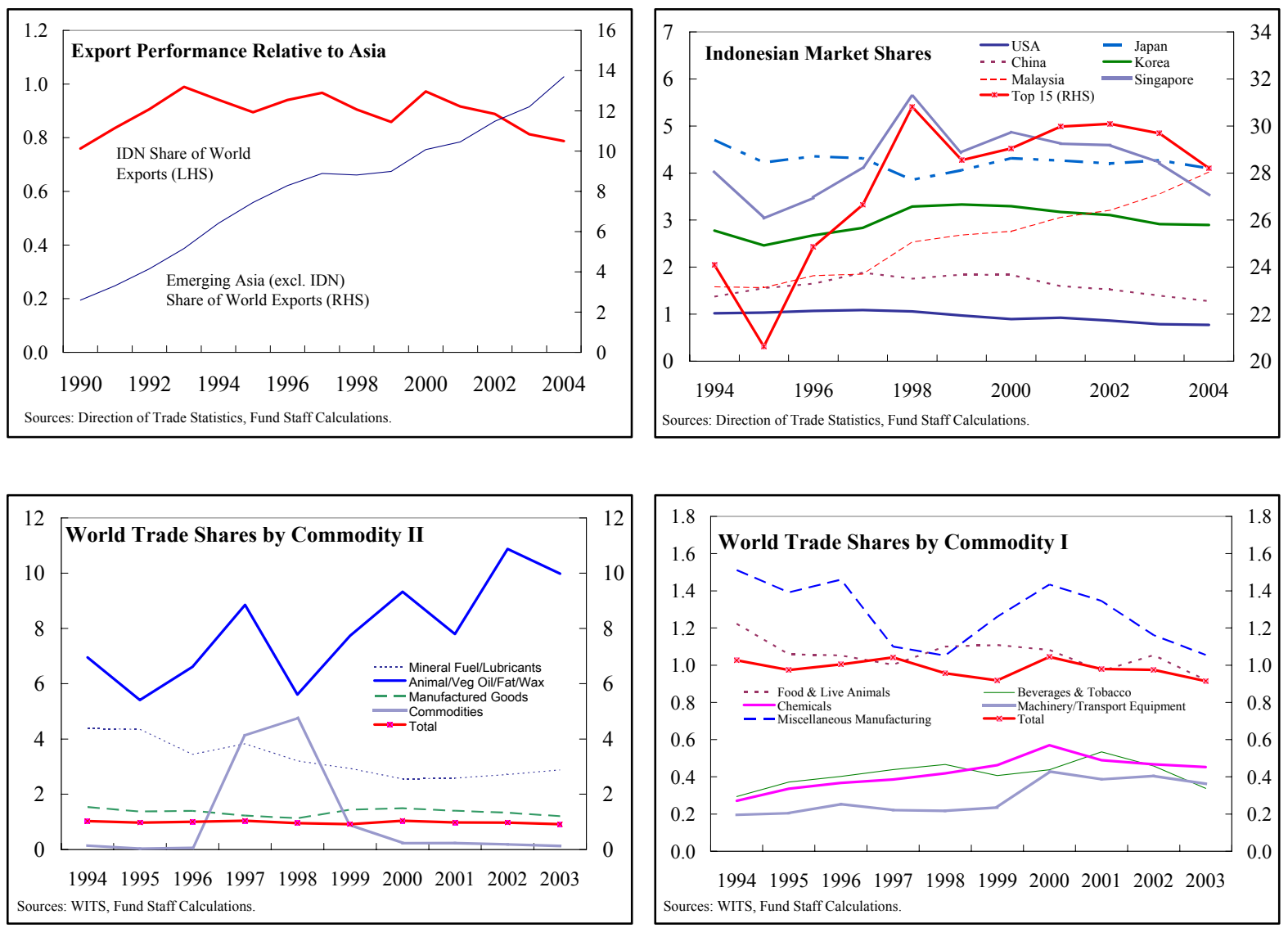

$\bullet$

Indonesia's export base has narrowed. Looking at the composition of Indonesia's exports by commodity group and its share of world exports by commodity reveals increasing concentration in export categories (Table). Prior to 1998, Indonesia's export growth was robust (9.5 percent annually in 1992-1997) and spread across a range of goods. After the crisis, export growth has been weaker (4.6 percent annually in 1997-2003), and more narrowly concentrated, with the oil and gas sector and machinery and transport equipment sectors contributing almost half of growth each. Revealed comparative advantage figures, which show the relative importance of a commodity group in Indonesia's exports in comparison with the group's relative importance in world trade, suggest a similar pattern. ${ }^{6}$ The revealed comparative advantage ratios were either constant or declining in seven of ten export categories since 2000, suggesting that the narrowing of the export base was not due to increasing specialization in areas in which Indonesia has an advantage.

${ }^{6}$ A ratio above 1 indicates a comparative advantage in the product, in the sense that Indonesia's exports are more concentrated in that group of goods than overall world trade, which is presumed to reflect an advantage in producing that commodity. 


\begin{tabular}{|c|c|c|c|c|c|c|c|c|c|}
\hline \multicolumn{10}{|c|}{ Composition of Exports } \\
\hline & \multicolumn{2}{|c|}{ 1992-1997 } & \multicolumn{2}{|c|}{$1998-2003$} & \multicolumn{5}{|c|}{ Revealed comparative advantage } \\
\hline Total & 9.5 & 100 & 4.6 & 100.0 & & & & & \\
\hline Crude materials ex. & 10.7 & 8.9 & 7.4 & 13.1 & 2.25 & 2.23 & 2.42 & 2.59 & 2.76 \\
\hline Mineral fuel/lubricants & 3.1 & 9.7 & 10.7 & 51.4 & 3.19 & 2.45 & 2.64 & 2.79 & 3.15 \\
\hline Animal/veg. oil/fat/wax & 24.5 & 7.8 & 14.7 & 12.2 & 8.42 & 8.94 & 7.96 & 11.16 & 10.91 \\
\hline Chemicals/products n.e.s. & 18.7 & 5.5 & 10.1 & 10.6 & 0.5 & 0.55 & 0.5 & 0.48 & 0.49 \\
\hline Manufactured goods & 2.8 & 6.5 & 5.0 & 19.7 & 1.57 & 1.43 & 1.43 & 1.37 & 1.32 \\
\hline
\end{tabular}

- The "technological intensity" of Indonesia's exports has also suffered. This measure indicates that the weakness in export growth has been concentrated in the "mediumtech" and "high-tech" sectors, reinforcing the view that the performance of the manufactured goods sector has deteriorated since the crisis.

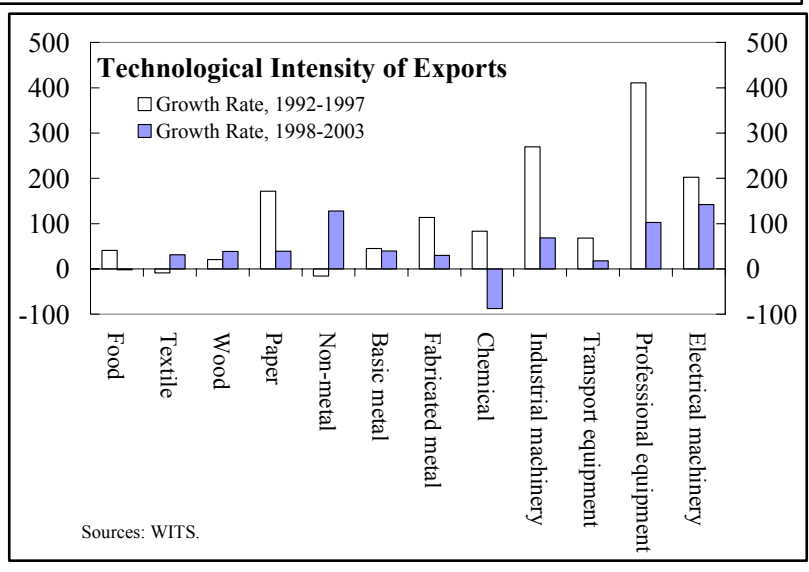

The export performance of the key oil and gas sector has not lived up to its potential. The increase in petroleum export values has been driven by higher oil prices, as oil production has fallen throughout the period, while gas production has remained largely flat. Oil and gas exports have remained fairly constant as a share of total

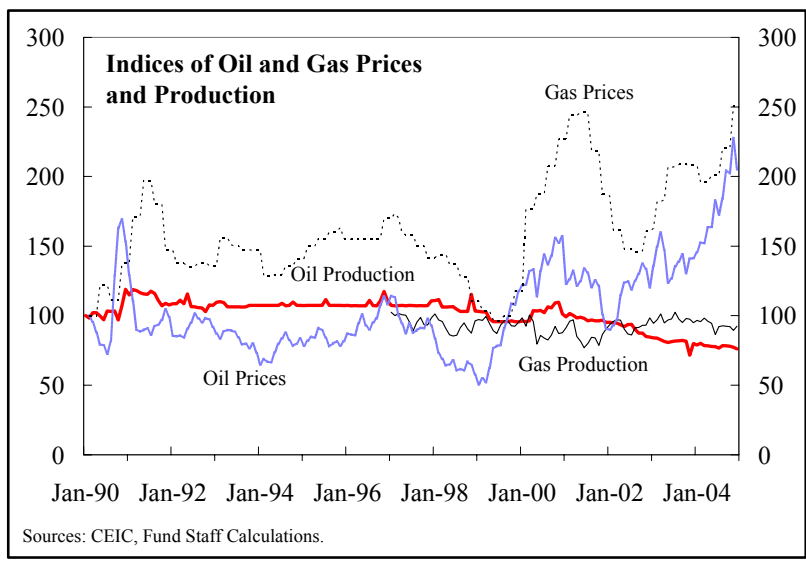
exports, averaging between 20 percent and 25 percent of total exports by value since 1994 . This outcome has significant implications for Indonesia's external balance and exchange rate, since it suggests that the "windfall" element of higher oil prices has supported a higher level of real activity that may not be justified by underlying export performance. If commodity prices were to decline, Indonesia could face external sector pressures going forward. 


\section{Econometric Estimates of the Equilibrium Real Exchange Rate}

5. From a broader macroeconomic perspective, the equilibrium real exchange rate can be thought of as the level of the exchange rate that is consistent with internal and external balance, or a "sustainable" level of the current account. Recent macroeconomic developments in Indonesia are relatively favorable from this perspective. Higher commodity prices have helped to stabilize external balances by permitting current account surpluses to be used to lower the debt ratio, underpinning the present level of the exchange rate.

\section{Econometric analysis finds} evidence that Indonesia's equilibrium real exchange rate is strongly influenced by the terms of trade, and commodity prices in particular. For instance, Cashin, Céspedes, and Sahay (2002) conclude that the rupiah is a "commodity currency," while Lee et. al. (2005) suggest that the real exchange rate is cointegrated with real GDP per worker, the terms of trade, and net foreign assets. The co-movement of the equilibrium real exchange rate

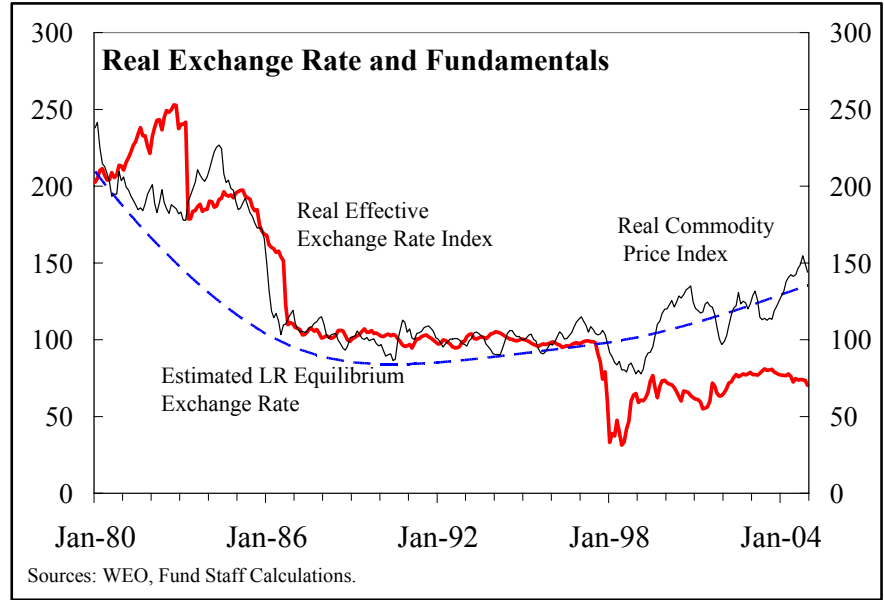
with real commodity prices is confirmed by cointegration tests. ${ }^{7}$ Estimating an errorcorrection equation, and fitting the equation with long-run equilibrium values, suggests that the real exchange rate remains undervalued. ${ }^{8}$

\section{Conclusions}

7. While the evidence is mixed, on balance, the above analysis suggests that Indonesia's competitiveness is adequate. Most measures of the real exchange rate remain below the level of the early 1990s, and point to a steady improvement in competitiveness over the last one to two years. Moreover, estimates of the equilibrium exchange rate

${ }^{7}$ The real commodity price index is constructed using price data for Indonesia's eight largest commodity exports (cocoa, copper, crude oil, natural gas, hard logs, palm kernel oil, rubber, and coal), weighted by their respective trade shares in 2003, deflated by the price deflator for manufactured goods for all industrial countries.

${ }^{8}$ A vector error correction mechanism model was estimated using annual data from 1980 to 2004. The regression related the real exchange rate index to GDP per worker, terms of trade, and government consumption. 
suggest some room for appreciation. The analysis of export performance, on the other hand, underscores the need for caution in assessing the level of competitiveness. 


\section{References}

Bayoumi, Tamim, Jaewoo Lee, and Sarma Jayanthi (2005), "New Rates from New Weights," IMF Working Paper No. 05/99 (Washington: International Monetary Fund), available on the web at http://www.imf.org/external/pubs/ft/wp/2005/wp0599.pdf.

Burgess, Robert, Stefania Fabrizio, and Yuan Xiao (2004), "Competitiveness in the Baltics in the Run-Up to EU Accession," Country Report No. 03/114, April 2003 (Washington: International Monetary Fund), available on the web at http://www.imf.org/external/pubs/ft/scr/2003/cr03114.pdf.

Cashin, Paul, Luis Céspedes, and Ratna Sahay (2002), "Keynes, Cocoa, and Copper: In Search of Commodity Currencies," IMF Working Paper No. 02/223, December (Washington: International Monetary Fund), available on the web at http://www.imf.org/external/pubs/ft/wp/2002/wp02223.pdf.

Cashin, Paul and C. John McDermott (2004), "Parity Reversion in Real Exchange Rates: Fast, Slow or Not at All?" IMF Working Paper No. 04/128 (Washington: International Monetary Fund), available on the web at http://www.imf.org/external/pubs/ft/wp/2004/wp04128.pdf.

European System of Central Banks, Monetary Policy Committee (2005), "Competitiveness and the Export Performance of the Euro Area," Occasional Paper Series No. 30, June (Frankfurt: European Central Bank), available on the web at http://www.ecb.int/pub/pdf/scpops/ecbocp30.pdf.

Hinkle, Lawrence E. and Peter J. Montiel (1999), "Exchange Rate Misalignment Concepts and Measurement for Developing Countries," World Bank Research Publication (Oxford: Oxford University Press) available on the web at: http://wwwwds.worldbank.org/servlet/WDSContentServer/WDSP/IB/2001/12/11/000094946 01112104010388/Rendered/PDF/multi0page.pdf

Lee, Jaewoo, Gian Maria Milesi-Ferretti, Luca Ricci, and Sarma Jayanthi (2005), "Equilibrium Real Exchange Rates: Estimates for Industrial Countries and Emerging Markets," unpublished paper, January (Washington: International Monetary Fund).

Milesi-Ferretti, Gian Maria and Assaf Razin (1997), "Current Account Sustainability: Selected East Asian and Latin American Experiences," NBER Working Paper No. 5791, March (Cambridge M.A.: National Bureau of Economic Research) available on the web at http://papers.nber.org/papers/w5791. 
Organization for Economic Cooperation and Development (1992), "Technology and the Economy: The Key Relationships," The Technology/Economy Program (Paris: Organization for Economic Cooperation and Development).

Ramakrishnan, Uma and Athanasios Vamvakidis (2002), "Forecasting Inflation in Indonesia," IMF Working Paper No. 02/111, June (Washington: International Monetary Fund), available on the web at http://www.imf.org/external/pubs/ft/wp/2002/wp02111.pdf.

Roubini, Nouriel and Paul Wachtel (1998), "Current Account Sustainability in Transition Economies," NBER Working Paper No. 6468, March (Cambridge M.A.: National Bureau of Economic Research) available on the web at http://papers.nber.org/papers/w6468.

Turner, Anthony G. and Stephen S. Golub (1997), "Towards a System of Multilateral Unit Labor Cost-Based Competitiveness Indicators for Advanced, Developing, and Transition Countries," IMF Working Paper No. WP/97/151, November (Washington: International Monetary Fund), available on the web at http://www.imf.org/external/pubs/ft/wp/wp97151.pdf.

World Integrated Trade Solution (WITS), "Trade Data Warehouse" (Washington: World Bank), available on the web at http://wits.worldbank.org/.

Zanello, Alessandro and Dominique Desruelle (1997), “A Primer on the IMF's Information Notice System,” IMF Working Paper No. WP/97/71, May (Washington: International Monetary Fund), available on the web at http://www.imf.org/external/pubs/ft/wp/wp9771.pdf. 


\section{The OIl and Gas Sector: Prospects And Policy Issues ${ }^{1}$}

\section{A. Introduction}

1. Although the petroleum sector remains a major part of Indonesia's economy, its importance has declined over time. While Indonesia ranks seventeenth and eighth among world producers of oil and of gas, respectively, ${ }^{2}$ dwindling investment, structural factors (such as aging fields), increasing costs, and high levels of fuel subsidies have over time eroded the contribution of the sector. Indeed, Indonesia's oil production has been declining, remaining well below its OPEC quota for several years, proven reserves have halved since 1983 to less than 5 billion barrels, and Indonesia is currently a net oil importer. Gas production increased rapidly from a low base in the 1970s to the mid-1990s, but has since stagnated.

2. This chapter reviews the contributions of the oil and gas sector to the Indonesian economy and its future prospects. After an overview of recent developments and policy initiatives, the chapter discusses Indonesia's regulatory and fiscal arrangements in an international context, the government's energy reform strategy, and options for attracting investment.

\section{B. Recent Developments and Policies}

3. Both oil and gas production has stagnated in recent years. In 2004, Indonesia produced 1.04 million barrels of oil per day (mbd), well below the peak of $1.6 \mathrm{mbd}$ reached in 1991 and also more than 20 percent below its OPEC quota. The decline in oil production has been especially rapid in recent years, with an average fall of about 6 percent annually during 2000-2004. Gas production has stagnated at or below 8 billion cubic feet per day in the last few years. As a result, the overall contribution of the petroleum sector has declined over time:

- The sector currently accounts for around 10 percent of GDP, down from 12 percent in 1991 , notwithstanding the currently high oil prices.

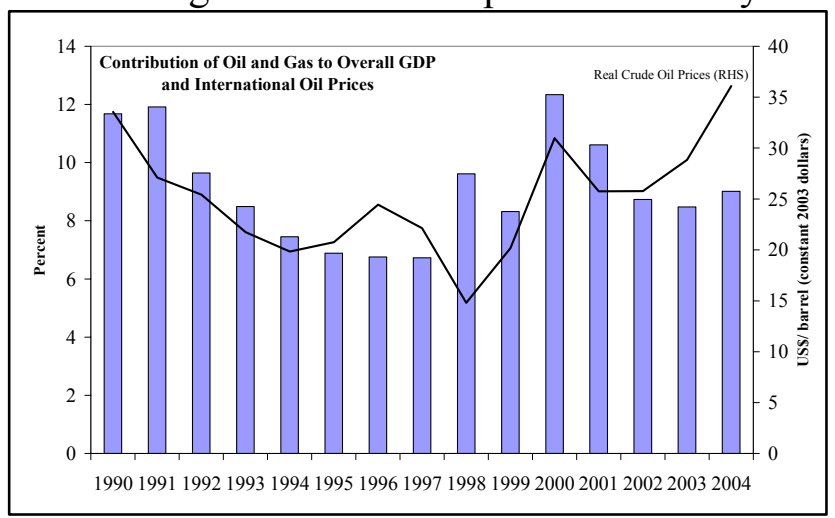

\footnotetext{
${ }^{1}$ Prepared by Nita Thacker and Yougesh Khatri (both APD). The chapter draws on research done by Daniel Chirpich during a 2004 summer internship at the IMF's Jakarta office.

2 Indonesia's proven oil and gas reserves account for a relatively small share of the world's total reserves ( 0.4 percent and 1.5 percent, respectively), while oil and gas production represent 1.5 percent and 2.8 percent of world production, respectively.
} 
- Oil and gas related export earnings totaled around US\$18 billion or 25 percent of total export value in 2004, compared to over 40 percent in 1990, and around 60 percent in the early 1980s. At the same time, oil imports have been on the rise, with oil and gas imports amounting to some US\$11 billion or nearly 25 percent of total imports value in 2004, compared to less than 10 percent a decade ago. In fact, Indonesia has become a net importer of oil, although it still remains a net petroleum exporter thanks to its gas exports.

- In 2004, oil and gas revenue accounted for about 27 percent of government revenue, compared to over 40 percent in $2000 .^{3}$ The sector's net contribution to the budget has been further eroded by large fuel subsidies, to keep domestic consumer prices down, which amounted to 3 percent of GDP in 2004.

\section{Oil consumption has been growing}
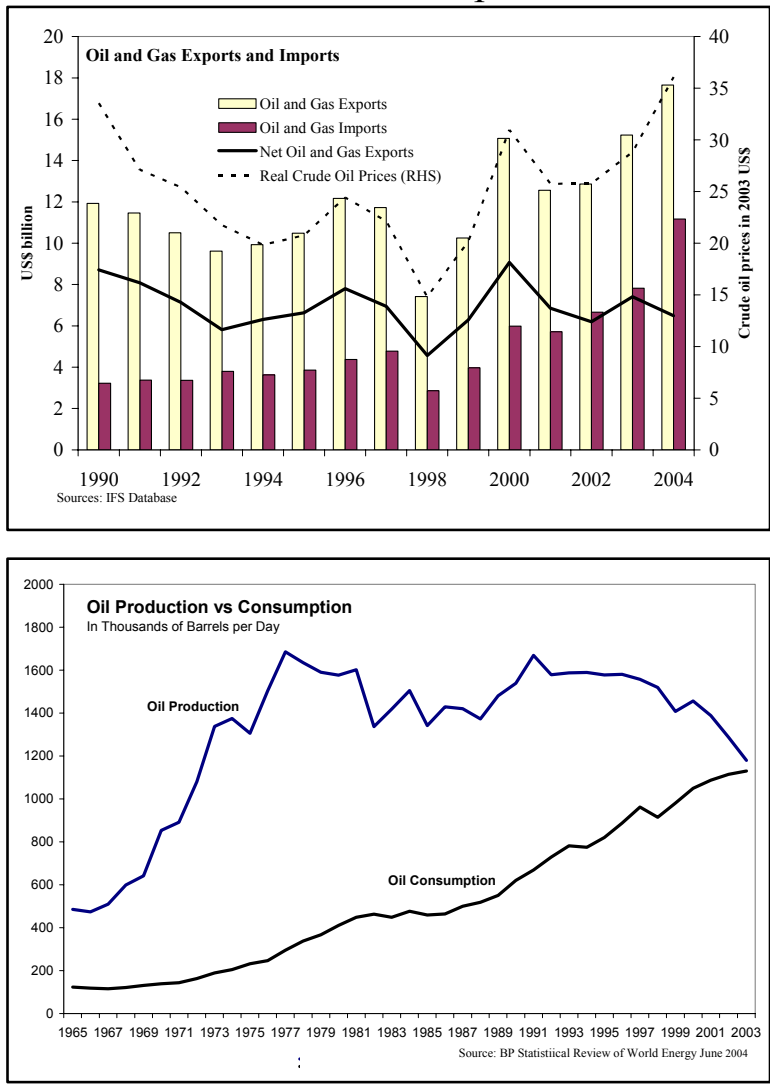

rapidly while production has been declining. Oil consumption has increased at an average rate of around 5 percent since 1990 while production has been declining as discussed above. A major factor driving oil consumption in Indonesia is the low domestic price of fuel. ${ }^{4}$

\section{Gas production is double the level of gas consumption, but consumption has} been increasing at a faster pace than production. Since 1990, gas production growth at 3.7 percent per annum has been below consumption growth averaging some 4.2 percent; however, production levels are still double that of consumption so that gas has become increasingly important to the Indonesian economy.

\footnotetext{
${ }^{3}$ As a result of decentralization, a large share of oil revenues are now transferred to local governments.

${ }^{4}$ In 2004, pump prices for gasoline in Indonesia were US\$0.27 per liter, compared to US\$0.89 in Singapore, US\$0.87 in India, and US\$1.54 Hong Kong SAR (GTZ survey, 2004). Even after the March 2005 fuel price hikes (averaging 29 percent across products), pump prices remain among the lowest in the world, reflecting still high levels of subsidization of fuel consumption by the government.
} 


\section{Exploration expenditure in real} terms and new field exploration drilling has fallen to 35 year lows (IPA, 2004). While development expenditure has been rising, this reflects in part rising unit costs. Moreover, overall production costs are rising as fields mature and operators face higher costs, including labor costs and local government charges.

\section{The number of production sharing} contracts (PSCs) and technical assistance contracts (TACs) signed have also declined. Such contracts fell from a peak of 21 in 1997, to two in 2002, following enactment of the new oil and gas law in 2001, but increased again to 17 in 2004. However, many of the more recent PSCs have been awarded to small and medium-sized companies that typically have only regional operations.

\section{Although there are some common factors that have affected investment in the} sector internationally, the declining trend in Indonesia is also indicative of the investment climate in the country. A recent study by IMF staff (2005) suggests that the relatively low real oil prices during the 1980s and 1990s and the volatility and unpredictability of these prices, combined with the substantial upfront outlays, the irreversibility of investment, and uncertainty about future cash flows, constrained global exploration activity. While these factors could partly explain the low investment in the Indonesian oil and gas sector, country-specific factors, including weaknesses in the broader investment climate - such as contractual, legal, and policy certainty, labor market rigidities, and infrastructure weaknesses - have also been important. ${ }^{5}$ Specific factors which may have dampened investment in Indonesia include:

- Slow implementation of the new oil and gas law passed in 2001: The new law changed the regulatory structure in the oil and gas sector with the creation of two new agencies, BPMigas and BPH Migas, now responsible for upstream and downstream regulations, respectively, and transformation of state-owned petroleum company Pertamina (previously responsible for production and regulation) into a limited liability company (Box IV.1). The associated implementing regulations were delayed, creating regulatory uncertainty in the sector, although all but one have now been completed.

- Amendments to the law required by the Constitutional Court are still pending: These amendments relate to the domestic market obligation of oil and gas companies (so that they may now be required to sell at least 25 percent as opposed to up to 25 percent) in the domestic market; and to the setting of oil and gas prices.

\footnotetext{
${ }^{5}$ Chapter V of IMF Country Report No. 04/189 provides a fuller description http://www.imf.org/external/pubs/cat/longres.cfm?sk=17502.0.
} 
- Proliferation of regulations: In the wake of decentralization, oil and gas companies often face increasing and conflicting regulations adopted by regional governments, which may be different from those agreed in the companies' contracts with BPMigas.

- Negative sentiment and forgone production related to high-profile protracted negotiations: ExxonMobil and Pertamina have been in protracted negotiations over the Cepu oilfield (relating to an extension of Exxon Mobil's contract) where ExxonMobil recently discovered large reserves. The latest reports suggest that an agreement has now been reached.

- Regulatory uncertainty regarding taxes and import duties: Some PSCs include VAT exemptions, but such exemptions (and contracts) have in some cases been reviewed by the government and the exemptions withdrawn. More recently, the government has announced VAT exemptions on capital imports by oil and gas companies.

- Delays in VAT refunds and other tax disputes: While VAT used to be refunded by Pertamina to PSC companies, the refunding is now the responsibility of the upstream regulator, and there are reports of long delays in refunds.

\section{Indonesia's Fiscal Regime-An International Perspective}

9. Many oil-producing countries rely on foreign participation as a means to attract investment and know-how. Given the large-scale outlays required for exploration, oil companies typically require government incentives. While the overall framework for oil exploration and production is generally through production-sharing agreements and, to a lesser degree, joint ventures, the terms of the production-sharing agreements vary not only from country to country but also within countries depending inter alia on the location of the oil wells. For example, off-shore oil exploration usually requires more generous terms on PSCs to recover the cost than on-shore exploration. Country risk also plays an important role as a motivation for government incentives. Finally, the fiscal regime - in terms of both corporate taxes and tax exemptions - is an important determinant in an oil company's choice of countries.

10. Indonesia's PSCs have become more generous over time. Under the early PSCs, contractors received 15 percent and the government received 85 percent of the total oil revenues after production costs were deducted. More recently, the PSC terms have become more generous. In 2003, in 11 of the 15 PSCs signed, the share of the contractors increased to a range of 20-25 percent (with most receiving 25 percent) for oil, and 35-45 percent for gas (with an average of 40 percent). In 2004, 10 of the 15 PSC contracts awarded provided shares to contractors in the range of 20-35 percent for oil, and 35-40 percent for gas.

\section{As regards the fiscal and regulatory regime, Indonesia's income tax rates are} comparable to those in the region (Table 1). Indonesia's income tax rate on the oil and gas sector is similar to that of the countries in Asia but Indonesia has no resource rent costs 
(RRCs). On the other hand, Indonesia's PSC terms give the government one of the highest shares in oil revenues in the region. RRCs generally apply only when a company is making excess profits, and become binding only when oil prices are very high. In contrast, favorable terms on PSCs have an immediate effect on cash flow once sales begin. In that respect, generous terms on PSCs are preferred by companies. Under the current outlook for oil prices, the absence of RRCs may partly offset the less generous terms on PSCs. Nevertheless, investors have also sought better terms on PSCs to cover the costs, especially for aging fields, and also for political and regulatory uncertainty as they seek to maximize risk-adjusted returns.

\section{Economic Policies to Attract Investment}

\section{Future production levels will depend on new fields coming on stream, structural} factors, and future investment. The near term profile of oil and gas production would depend on important new finds such as Cepu. ${ }^{6}$ Even with new production coming on stream as currently expected, the bulk of production would come from mature fields in which output is declining. Also, new exploration is increasingly in more difficult or "frontier" regions, entailing higher exploration costs. Future oil and gas demand will depend, among other things, on Indonesia's petroleum pricing policy and broader energy strategy, as well as international price developments and overall economic growth. Box VI.2 presents technical scenarios that illustrate the long-term implications of different outcomes in the petroleum sector.

\section{With this is mind, the new government has been working to attract foreign} investment in the petroleum sector and at the same time has devised a new energy policy. Important developments in this regard are:

\section{- A renewed push to complete the new regulatory framework and clarify issues} relating to tax and duties under existing PSCs. The new framework constitutes major improvements in the environment for investment in the upstream oil and gas sector. Further progress to reduce the regulatory uncertainty would be achieved through completion of the pending amendments to Law 22/2001 (as required by the Constitutional Court), and the clarification of conflicting and overlapping regulations, such as those between central and local governments.

\footnotetext{
${ }^{6}$ Major new production potential include: the Cepu field which could boost oil production by up to 15 percent of current oil production not to mention its substantial gas reserves and the Tangguh project (comprising on-shore and off-shore blocs in Irian Jaya) which is reported to have around 14 TCF of gas and initial production capacity of 7 million tons/year.
} 
- Improvements in fiscal incentives, such as the enhancement of PSC terms for contractors, and incentives to boost production in marginal oil fields. ${ }^{7}$

- Conclusion of outstanding disputes and contract discussions, including the Cepu field contract negotiations. A conclusion of these discussions would also be beneficial to the overall investment climate. A resolution of long outstanding issues relating to tax refunds and rebates would also contribute in this regard.

- Increasing significantly the number of blocks offered. In this regard, 27 blocks are planned to be offered in June 2005, of a total of 70 blocks planned for to be offered during 2005-2006.

- A new energy policy aimed at better managing and utilizing energy resources. The recently launched Blueprint for National Energy Development, 2005-20, outlines an integrated energy management strategy. On the supply side, the strategy aims to augment energy production whilst diversifying fuel sources in power generation, and on the consumption side it aims to improve efficiency of energy use. The strategy recognizes the need to move energy consumer prices to "economically viable" levels and targets this to be completed by 2010 . Other key objectives of this strategy are, by 2020, to: (i) reduce the role of crude oil in power generation from around 50-55 percent to 10-15 percent (through increasing the use of coal, gas and geothermal power); (ii) reduce the intensity of energy use by 1 percent a year; (iii) improve energy infrastructure, such as oil and gas pipelines; and (iv) create a secure supply of energy.

\section{E. Conclusions}

\section{While Indonesia's oil and gas sector will play a diminishing role in the economy} going forward, it will remain a key sector, and the renewed policy efforts are important in augmenting investment and production. The government is aiming to boost investment and production, while on the demand side, reduce reliance on oil and move toward more efficient utilization of oil and gas resources, including through pricing policies. The major regulatory changes introduced since 2001 have been an important step in this regard. The key implementing regulations are largely complete, and some of the outstanding issues relating to VAT and import duty obligations have been settled recently. Assuming the amendments required by the Constitutional Court are completed quickly and flexibly, and given the various (fiscal and other) initiatives being offered by the government, developments in regard to investment and production may turn around. Nevertheless, in the longer run, Indonesia

\footnotetext{
${ }^{7}$ Under a recently issued ministerial regulation (08/2005), contractors can claim a refund of 20 percent of operating costs incurred in the establishment of a viable producing marginal oil field, subject to annual review and a cumulative rate of return ceiling of 30 percent, at which point the incentive would cease.
} 
needs to prepare for major structural changes as the contribution of the oil and gas sector to GDP, foreign exchange earnings and government revenues inevitably will decline over time. 


\section{Box VI.1. Regulatory Developments in the Oil and Gas Sector}

\section{Previous Regulatory Structure}

Prior to 2001, Pertamina acted both as the state oil and gas company and as the industry regulator-a situation which created conflicts of interest and related problems for investment, governance and transparency in the sector. Law No. 8-1971, established Pertamina as both operator and regulator with duties ranging from the tendering of blocks, managing data, awarding production sharing contracts (PSCs), to operating the downstream sector. Pertamina operated all domestic refineries and was responsible for ensuring the domestic supply of refined oil products. In addition, Pertamina was the sole buyer of all natural gas produced domestically and had the sole responsibility for negotiating contracts for the export of LNG. This system limited competition in the downstream sector and introduced a number of distortions. The monopoly and public obligation assigned to Pertamina, along with the petroleum subsidies, led to underinvestment in the downstream sector. Indonesia's diminishing levels of oil production and reserves underscored the need for a more effective regulatory regime.

\section{New Regulatory Structure}

Indonesia passed a new oil and gas law on November 23, 2001 that introduced major changes in the regulatory structure as part of the deregulation and reform effort in the energy sector. Law No. 22-2001 provided for a clear separation between upstream and downstream activities. It transferred regulatory authority from Pertamina to the Directorate General of Oil and Gas (DG MIGAS) in the Ministry of Energy and Mineral Resources, and to two new regulatory agencies: Badan Pelaksana Minyak dan Gas Bumi (the "Implementing Body for Oil and Gas" or BP MIGAS) for the upstream sector, and Badan Pengatur Hilir Minyak dan Gas Bumi ( "the Regulatory Body for Downstream Oil and Gas" or BPH MIGAS). Government Regulation 31 of 2003, established Pertamina as a state owned limited liability company. Under the new law, the tendering of blocks for exploration come under the authority of DG MIGAS, which is responsible for gathering preliminary data on blocks, conducting the auctions, awarding contracts, and issuing the contracts. The final contracts, however, are signed by the newly created upstream regulatory authority, BP MIGAS, which is responsible for managing contracts until their termination, at which time they revert back to DG MIGAS. BP MIGAS was established by Government Regulation 42, issued July 16, 2002. BPH MIGAS, which was established on December 30, 2002, was created by Regulation 67 of 2002 and Presidential Decree number 86 of 2002. As the regulatory agency for the downstream oil and gas sector, its responsibilities include domestic fuel distribution, national oil fuel reserves, tariffs for natural gas pipelines, and gas prices for households and small customers. Law No. 22-2001 also established the liberalization of the downstream sector. Pertamina is set to lose its monopoly and its public service obligation (its responsibility to ensure the national fuel supply) at the end of 2005. New entrants and licenses for the downstream sector will be issued by BPH MIGAS.

These new laws and regulations largely complete the regulatory framework for the oil and gas sector, although amendments following the Constitutional Court review of the law are pending. Many of the important subsidiary regulations under Law No. 22-2001 have now been issued including those establishing Pertamina as a private company, establishing BP MIGAS and BPH MIGAS, and more recently (October 2004) two separate implementing regulations, for BP MIGAS and BPH MIGAS relating to the operational aspects of these agencies. Industry representatives report some remaining conflicts or ambiguities among various statutes and some unintended consequences which may continue to act as disincentives to investors. Finally, the Constitutional Court's recent review of Law 22/2001 (in the context of Article 33 of Indonesia's Constitution), required amendments relating to the domestic market obligation of gas producers, and to the pricing of gas and fuel oil (which was market determined under Law 22/2001). Thus, there remains some work to complete the regulatory framework and remove uncertainty and disincentives for investment. 


\section{Box VI.2. Contribution of the Oil and Gas Sector: Alternative Scenarios}

The scenarios below are based on three simple assumptions-production increasing by 3 percent a year, remaining constant, and declining by 3 percent a year. Under Scenario 1, where the government successfully tackles the impediments to investment, production increases by 3 percent a year (ignoring the long gestation between investment and actual production), although oil consumption still exceeds production. In this scenario, positive net gas exports would persist throughout the period. In Scenario 2, where more modest reforms and investment result in the maintenance of the current level of oil and gas production, the imbalance between oil demand and supply quickly increases and net oil imports increase. Meanwhile, gas demand would continue to exceed supply for some time. In Scenario 3, where production is expected to decline by 3 percent a year, a large imbalance emerges early on, such that Indonesia becomes a net importer of oil and gas and the contribution of the sector to GDP, exports and government revenue
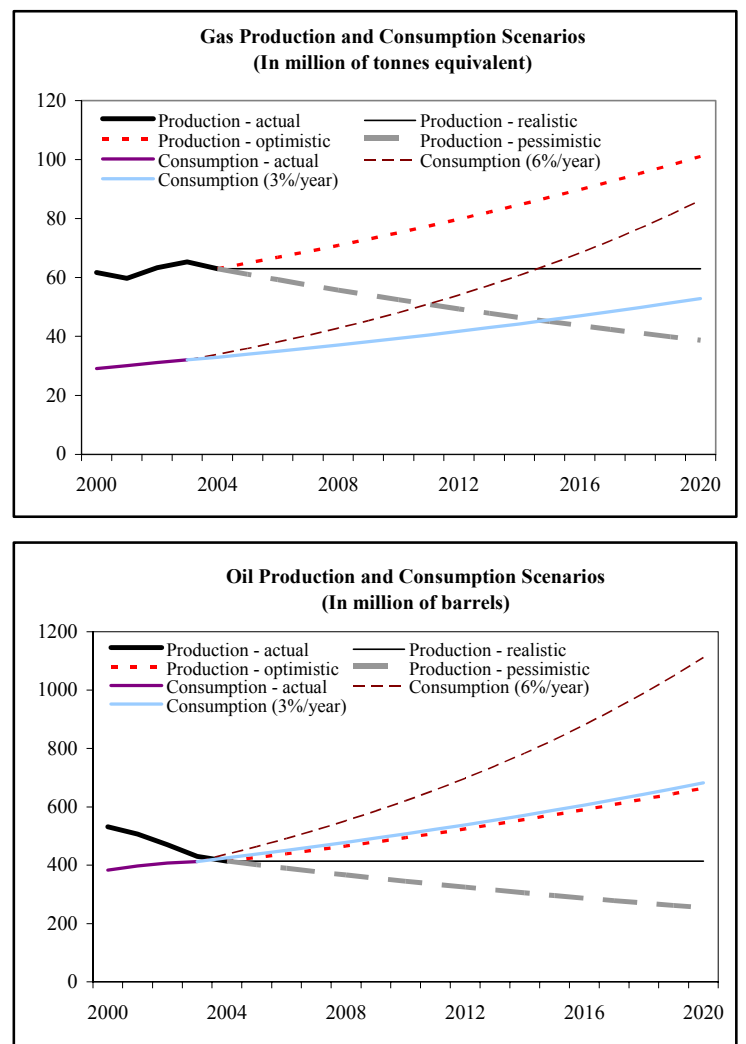
declines rapidly.

\section{Even under the most optimistic scenario, the relative contribution of the oil and gas sector to the Indonesian economy would decline markedly within a decade. If oil} and gas production grew by 3 percent a year, by 2015 , its share of GDP would halve and its contribution to government revenue would fall below 17 percent. In the pessimistic case

\begin{tabular}{|c|c|c|c|c|c|}
\hline \multicolumn{6}{|c|}{$\begin{array}{l}\text { Indonesia: Long-Term Implications of Oil and Gas Sector Growth/Stagnatic } \\
\text { Composition of GDP, Exports, and Government Revenue }\end{array}$} \\
\hline & 2001 & 2004 & 2010 & 2015 & 2020 \\
\hline & & & \multicolumn{3}{|c|}{ (in percent) } \\
\hline \multicolumn{3}{|c|}{ Scenario 1: Oil and gas production grows at 3 percent per year } & \multicolumn{3}{|c|}{ Projection } \\
\hline Share of oil and gas GDP/Total GDP & 10.6 & 9.0 & 7.0 & 5.0 & 3.6 \\
\hline Share of oil and gas exports/total exports & 21.9 & 24.5 & 22.2 & 18.1 & 14.7 \\
\hline Share of oil and gas revenue/total government rever & 34.6 & 26.5 & 22.1 & 16.8 & 12.6 \\
\hline \multicolumn{6}{|c|}{ Scenario 2: Oil and Gas production remains at current levels } \\
\hline Share of oil and gas GDP/Total GDP & 10.6 & 9.0 & 6.0 & 3.7 & 2.3 \\
\hline Share of oil and gas exports/total exports & 21.9 & 24.5 & 19.3 & 13.8 & 9.7 \\
\hline Share of oil and gas revenue/total government rever & 34.6 & 26.5 & 19.2 & 12.8 & 8.3 \\
\hline \multicolumn{6}{|c|}{ Scenario 3: Oil and Gas production declines by 3 percent a year } \\
\hline Share of oil and gas GDP/Total GDP & 10.6 & 9.0 & 5.0 & 2.7 & 1.4 \\
\hline Share of oil and gas exports/total exports & 21.9 & 24.5 & 16.7 & 10.3 & 6.2 \\
\hline Share of oil and gas revenue/total government rever & 34.6 & 26.5 & 16.5 & 9.5 & 5.2 \\
\hline
\end{tabular}
in which production declines by 3 percent per year, within a decade the sector would account for less than 3 percent of GDP, and around 10 percent of total exports and government revenue. Indeed, depending on the rate of growth of consumption and imports, net oil and gas exports would decline rapidly and Indonesia could become an overall importer of oil and gas within the next decade. While these scenarios are mechanical, they illustrate the importance of increased investment and production in the oil and gas sector 
Table 1. Comparison of Fiscal Terms for Selected Oil and Gas Producing Countries

\begin{tabular}{|c|c|c|c|c|c|c|c|}
\hline \multirow[t]{2}{*}{ Country } & Royalties & $\begin{array}{l}\text { Production } \\
\text { sharing } \\
\text { contracts } 1 /\end{array}$ & $\begin{array}{l}\text { Income } \\
\text { tax rate }\end{array}$ & $\begin{array}{c}\text { Resource } \\
\text { rent tax }\end{array}$ & $\begin{array}{c}\text { Dividend } \\
\text { withholding } \\
\text { tax }\end{array}$ & $\begin{array}{c}\text { State } \\
\text { equity }\end{array}$ & \multirow[t]{2}{*}{$\begin{array}{l}\text { Investment } \\
\text { incentives }\end{array}$} \\
\hline & \multicolumn{6}{|c|}{ (In percent) } & \\
\hline Indonesia & $\ldots$ & $75-90$ & 44 & None & 15 & 10 & Yes \\
\hline Kazakhstan & Up to 20 & Negotiable & $301 / 2$ & $0-30$ & 15 & 50 & $\ldots$ \\
\hline Malaysia & 10 & $50-70$ & 38 & 70 & None & 25 & Yes \\
\hline Mexico & None & None & $351 / 4$ & None & 7.7 & None & Yes \\
\hline Papua New Guinea & 2 & None & 45 & $20-25$ & None & $22 \frac{1}{2}$ & Yes \\
\hline Philippines & None & 60 & 32 & None & $15-32$ & None & Yes \\
\hline Qatar & None & $35-90$ & Govt. share & None & None & 65 & None \\
\hline Thailand & $31 / 2-101 / 2$ & None & 50 & None & 10 & None & Yes \\
\hline Vietnam & $6-25$ & $65-80$ & Govt. share & Formula & 15 & 15 & Yes \\
\hline
\end{tabular}




\section{References}

Hausmann, Ricardo and Roberto Rigobon, (2003), "An Alternative Interpretation of the "Resource Curse": Theory and Policy Implications", Fiscal Policy Formulation and Implementation in Oil-Producing Countries, International Monetary Fund, Chapter 2, p.13.

McPherson, Charles, (2003), "National Oil Companies: Evolution, Issues, Outlook", Fiscal Policy Formulation and Implementation in Oil-Producing Countries, International Monetary Fund, Chapter 7, p.184

“Presidents Report for CY (2004)," Indonesian Petroleum Association (IPA).

International Monetary Fund (2005), "World Economic Outlook,” April.

International Monetary Fund (2005), "Oil Market Developments and Issues" (www.imf.org). 


\section{Labor Market Policies and Job Creation ${ }^{1}$}

\section{A. Introduction}

1. Indonesia's steady pickup in growth in the last few years, averaging some 4.5 percent since 2000 , has not been accompanied by increases in employment levels. In fact, registered unemployment has edged up every year since the crisis, increasing from 4.8 percent in 1997 to almost 10 percent in 2004 . $^{2}$ At the same time, formal sector employment has declined.

2. The new government has made employment creation one of its central tenets. Its medium-term economic program aims to reduce the unemployment rate by half by 2009 . Improvements in the business climate to attract investment and create jobs, and programs to improve the skills of the working population, form central themes of the economic program.

3. This chapter discusses employment trends in Indonesia over the last several years and examines the reasons for the rising unemployment. Specifically, the chapter focuses on real wage growth, and the role of labor market legislation in explaining the underperformance of the labor market. The chapter also compares the trends in Indonesia with those in other countries in the region. It finds that labor legislation in Indonesia-which has added to the cost of labor-has played an important role in discouraging formal sector employment and in delinking growth and employment generation.

\section{B. The Indonesia Labor Market_-Some Stylized Facts}

4. Indonesia's working age population and labor force have steadily increased, but the new workers have not been absorbed. The labor force has expanded in line with population growth, with the participation rate around 67-68 percent. At the same time, unemployment has shown a steady upward trend. On average $2-2 \frac{1}{2}$ million Indonesians have entered the job market annually. However, the number of registered vacancies has declined every year since the crisis up until 2003, and the ratio of registered job applicants to available vacancies has increased two and a half fold. The resulting disappointment of people failing to acquire jobs may explain the decline in new labor force entrants in the last two years, despite

\footnotetext{
${ }^{1}$ Prepared by Nita Thacker (APD).

2 Since 2001, the Statistics Agency uses an internationally accepted definition of unemployment, which includes transitionally unemployed and discouraged workers. If these workers were excluded from the definition of the labor force, the unemployment rates for 2001-2004 would be 3-4 percentage points lower.
} 
an increase in the working age population by 2 percent as in previous years. At the same time, the increase in employed persons in 2004 may signal that the recent pickup in investment is in fact creating jobs (much of the GDP growth until last year was consumption driven). This would be similar to what happened in the late 1980 s, when rising investment levels created demand for labor, especially in export-oriented industries.

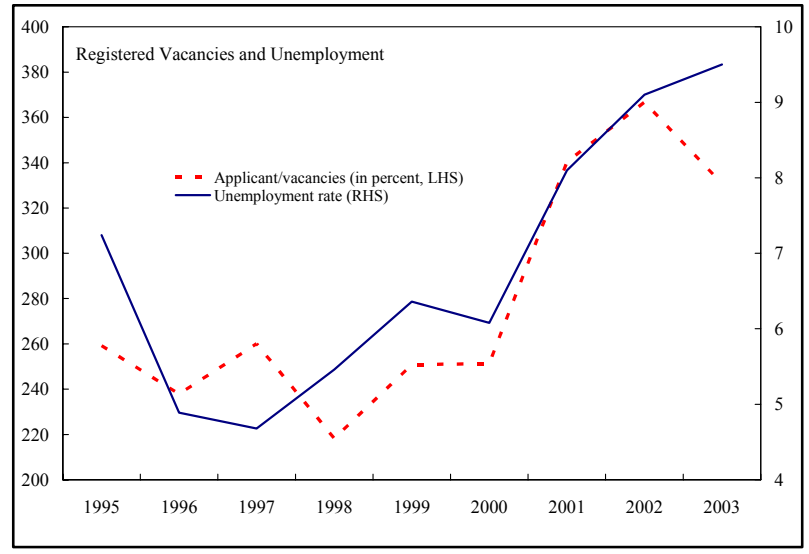

5. A sectoral analysis of employment trends suggests that informal sector

employment has risen since 1997, with the share of workers in this sector increasing from 54 percent in 1997 to about 60 percent in 2003. Thus, most new entrants absorbed have gone to the informal sector, most notably agriculture (Table 2 ).

6. Indonesia's unemployment rate is considerably higher than rates in other countries affected by the Asian crisis, such as Korea, Thailand, and Malaysia. Unlike the other countries in the region, unemployment in Indonesia has steadily increased since the crisis. In part this is because the faster pace of manufacturing growth in the other countries created a large number of jobs and helped to absorb the growing labor force. ${ }^{3}$

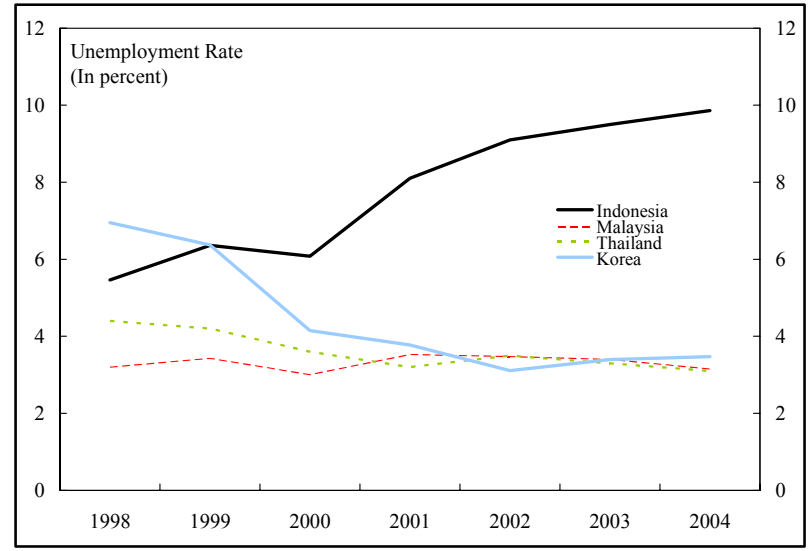

\section{Elasticity of Employment}

Empirical analysis confirms that the elasticity of employment creation has been low in Indonesia. The estimates suggest that a one percent increase in GDP results in 0.4 percent increase in employment. ${ }^{4}$

\footnotetext{
${ }^{3}$ Note that for Indonesia the relative performance may appear weaker because of the larger coverage of unemployment statistics since 2001, as explained in footnote 1.

${ }^{4}$ The elasticity was estimated using data for 1991-2004 with all variables in log, including a dummy variable for the two crisis years of 1997-98 and another regression using a dummy variable only for the pre-crisis period up to 1998 .
} 


$$
\begin{aligned}
\text { Employment }= & 1.26+0.41 \text { Real GDP } \\
& (1.3)(6.72)
\end{aligned}
$$

Moreover, the dummy variable distinguishing the pre- and post-crisis periods is significant, indicating a downward shift in the elasticity between the two periods, although the shift is not very large. 5 The results are consistent with the factor substitution and "induced innovation" theory, which suggests that firms will use/develop technology that substitutes the relatively expensive factor of production with other factors of production. The significant jump in minimum wages combined with increased labor market rigidities since 2000 (see below) could therefore explain the decline in elasticity between the pre-and post-crisis periods.

7. The estimates of the post-crisis elasticity suggest that employment should have increased with GDP growth, but rising labor costs has prevented this (see below). Although the elasticity measure suggests that employment should have increased given that growth has been trending up since 2000, employment has not, until recently, increased. Not only is Indonesia's recent performance disappointing in terms of job recovery, but it also stands in contrast to the pre-crisis years, when high investment, including FDI combined with export-led growth, was a major source of employment creation. During those years, wages increased as labor moved from low productivity jobs in agriculture to high productivity jobs in manufacturing and services. The unemployment rate during the first half of the 1990s was therefore only about 3-4 percent, while the period since the late 1990s has seen a doubling and tripling of the rate.

\section{Explaining Unemployment}

8. Since 2000, labor policy in Indonesia has focused on improving workers' rights and enforcing labor standards to improve working conditions. The Basic Manpower Act No. 13, 2003 is the current legal framework for labor regulations. Moreover, in 2000, Indonesia passed the Trade Union Act, which recognizes the freedom of association of workers. As a result, the largest three trade union federations now have close to 10 million formal sector workers (nearly one-third of those employed in the formal sector) with the number of trade union federations jumping from 11 in 1998 to 86 in 2004 and the number of plant level unions up from 2,836 in 1998 to 18,332 in 2004.

\section{Labor market rigidities have been cited as one of the most important causes of} rising unemployment. As shown in Table 3, Indonesia ranks least favorably in terms of standard indicators of labor market rigidities used by the World Bank in international comparisons. While Indonesia's per capita income is less than one-fourth of the region, firing costs are about three times the regional average. In a survey of 700 firms conducted by the World Bank, labor market rigidities, most importantly minimum wages, hiring and firing

\footnotetext{
${ }^{5}$ In comparison, Isard and Nazar (2000) found that the elasticity of employment during the pre-crisis period (1977-1996) was in the 0.5-0.7 range.
} 
difficulties, relatively high severance pay, and outsourcing restrictions were cited among the key factors inhibiting investor interest in Indonesia. This section seeks to assess to what extent these elements have indeed hampered job creation. The Indonesian regulations are compared with those in neighboring countries to assess the extent to which they are out of line with the regional norms and with the U.S., which is often cited as the country with the most flexible labor market (Table 4).

\section{Minimum Wages}

10. While minimum wages (MW) were first introduced in the early 1970s, they have gained importance in recent years. Indeed, MW have risen quite sharply in the post-crisis period, increasing almost four-fold in some provinces. While the philosophy behind MW has been to enable workers to consume a minimum bundle of essential goods and services, like clothing, housing, transportation, and health services, the fact that the MW has outpaced labor productivity has meant rising unit labor costs for enterprises. Studies suggest that this has been a deterrent to wage employment. This situation has been exacerbated by the decline in investment, until recently, especially in labor-intensive export industries.

\section{When nominal minimum wages} tripled in the first half of the 1990s, labor

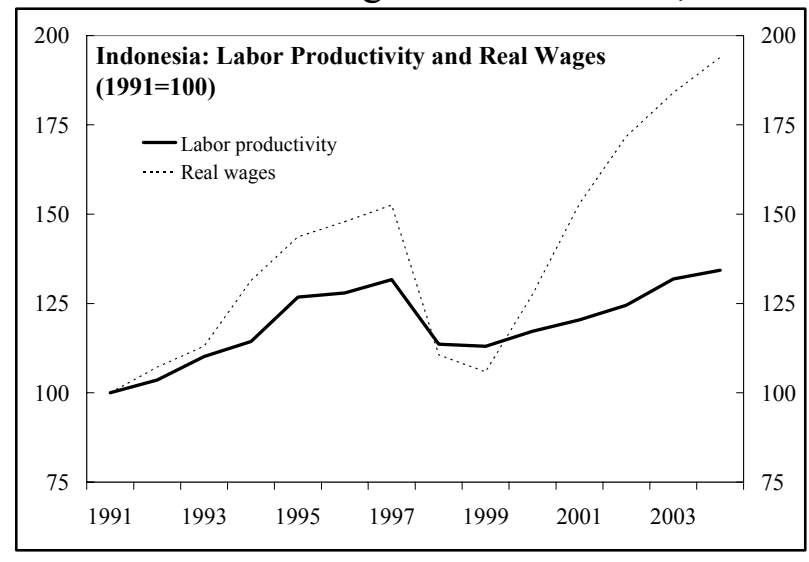
productivity was also rising. In 1998, in the immediate aftermath of the crisis, wages in real terms fell significantly given the high inflation during this period. In an effort to restore worker incomes, MW have been raised substantially since 2000, increasing much faster in real terms than average wages and per capita GDP. As a result, MW in real terms are now significantly higher than their pre-crisis peak in 1997. Indeed, since 2001, real minimum wages (averaged across provinces) have increased by more than 50 percent, while in Jakarta they have increased by over 60 percent. As this has happened against the backdrop of an economy where unemployment is increasing and formal sector employment declining, fewer workers have actually benefited from the new increases.

\section{A regional comparison shows that,} although MW are not high in absolute terms, they have recently outpaced productivity growth. In most countries, the MW serves as a floor and is the wage earned by the least skilled workers. However, in Indonesia average wages are

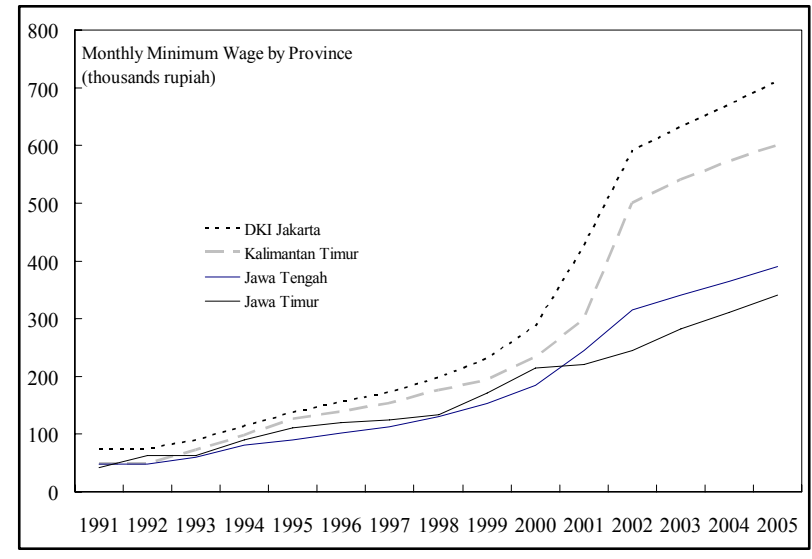
close to the minimum wage and the MW has been binding on firms. In fact, average real 
wages have increased far slower than average real minimum wages. As a result, more productive workers in some cases earn the same as less productive ones, limiting the scope for wage differentiations to reflect productivity levels of different workers and undermining incentives. Indeed, surveys of employers suggest that they are unable to give performancebased wages to motivate more productive workers.

13. Studies investigating the impact of MW on employment find mixed results. One of the first studies on the subject for Indonesia was done by Rama (1996), who found that the doubling of the MW in the early 1990s had resulted in a decline in employment in the range of 0-5 percent. Researchers at SMERU have also found a similar impact of MW on employment, with negative impacts stronger for females, youths and low educated workers. However, Islam and Nazara (2000) find that the MW policy has had no impact on unemployment.

\section{Our estimates show a negative impact of MW on employment. A multivariate} least squares regression of employment, on real minimum wages and GDP (all in log differences) gave the following results (with t-statistics shown in parentheses):

$$
\log (\text { Employment })=0.01-0.04 \text { dlog }(\text { Real } M W)-0.002 \log (\text { Real GDP })
$$

with the adjusted R-squared at 0.50 and the F-statistic at 9.6. Including a dummy variable to distinguish between the pre- and post-crisis period gave broadly similar results. The estimated relation suggests that changes in minimum wages have had a negative impact on employment growth, while real GDP growth is not significant. These results are consistent with developments in the post-crisis period, when growth has not resulted in an accompanying increase in employment. At the same time the R-squared and F-statistic imply that these variables do not capture the full story on employment developments. Other regulations like high severance pay and restrictions on outsourcing are possible explanations. ${ }^{6}$

\section{Severance Pay}

\section{Severance pay regulations have been revised twice since the crisis, in $\mathbf{2 0 0 0}$ and} 2003. Already in 1996, rates of severance pay were increased by about 50 percent for dismissals relating to economic reasons, that is, when a firm laid off workers due to downsizing or if the firm went bankrupt. In 2000, Ministerial Decree No. 150 raised severance rates further for workers with 10 or more years of service although long service pay remained unchanged. However, the decree also extended long service pay to all workers, including those who left voluntarily. For example, a worker with 20 years of more of service was now entitled to 7 months of salary instead of 5 months in severance pay and 7 months of

${ }^{6}$ Studies have shown these as important in many developing countries. 
salary in long service pay. In addition, all laid-off workers, regardless of the cause for dismissal, were entitled to a 15 percent gratuity on their severance pay and long service payments. The Manpower Act of 2003 further increased severance to 9 months of salary and long service pay to 7 months. If workers are laid off for economic reasons, severance pay is now 18 months of salary plus 7 months in long service pay adding up to a total of 25 months of salary. Employment in the manufacturing sector has been hardest hit by these regulations, as this sector employs the largest proportion of formal sector workers.

16. Severance regulations act like a "hiring" tax on employment and several studies, both for developed and developing countries have shown that increases in severance pay reduce the demand for labor. Severance pay in Indonesia is the highest in the region as shown in the chart based on labor laws of different countries. Furthermore, in a study done by USAID-GAIT, the authors show that severance pay in Indonesia is now among the highest in the world in relative terms, and similar to rates in Latin American countries, such as Honduras, Colombia, Peru and Ecuador, where unemployment rates are similarly high.

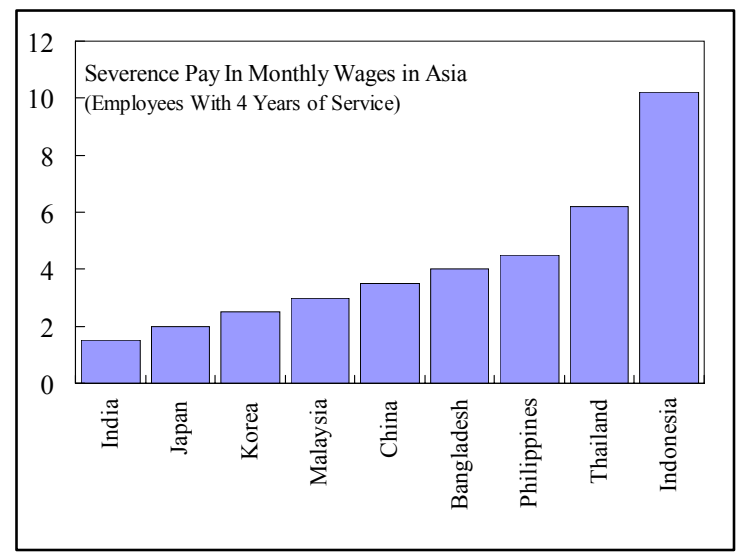

\section{Outsourcing and fixed term contracts}

17. Unlike advanced countries, where outsourcing usually relate to jobs being transferred to lower-income countries, in Indonesia it relates more often to intraindustry transfers of jobs. The 2003 Labor Law allows firms to outsource any "non-core" activities, while leaving the definition of what constitutes core versus non-core to negotiation between employers and employees. While this legislation is aimed to give flexibility to enterprises to decide what to outsource, labor unions have claimed that employers use this ambiguity to contract out work to temporary labor to avoid severance payments. While it is difficult to quantify its impact on employment generation, it appears that worker opposition to outsourcing may have resulted in negative investor sentiment toward labor-intensive industry in Indonesia vis-à-vis its neighbors.

\section{The regulation on fixed-term contracts now restricts such contracts to 2 years} with an additional year of extension allowed, compared to previous regulations which allowed 3-year fixed-term contracts with one time renewal. By limiting the length of fixed-term contracts to three years, including through renewability, this regulation seeks to improve job security for workers by ensuring that firms do not use such contracts as a means of avoiding severance pay by not offering permanent contracts even to workers needed for protracted periods. However, by limiting the enterprises' flexibility to hire temporary workers and thus reducing their adaptability to changes in product demand or technology, this regulation is viewed as inhibiting by investors.. 


\section{E. Policies for Employment Creation}

\section{A principal focus of the government's medium-term program is to halve the} unemployment rate by 2009. Beyond the general strategy to encourage investment through the maintenance of macro-economic stability and a deepening of structural reform, the program underlines three principal initiatives in regard to the labor market:

- Reducing unemployment through better targeted and active labor market programs.

- Improving the quality of human resources.

- Strengthening labor market institutions to promote a balance between employer and employee rights.

20. The discussion in this chapter suggests that the following actions would help increase job creation:

- $\quad$ Minimum wage to serve as a floor as in other countries, with actual wages decided by collective bargaining. In most developed countries, the government determines minimum wages, with the level set with a view to help protect workers with low skills. Actual wages are then set by negotiation between workers and employers. This system helps to protect low-skilled workers while allowing firms the flexibility to determine the wages they are willing to offer for different types of work based on labor productivity. In this context, the establishment of tripartite councils which bring together employers, employees and the government, acknowledges the need to keep labor productivity in mind when deliberating on minimum wage increases. Looking ahead, it will be important to set minimum wages such that the low skilled workers are protected while allowing a process of collective bargaining between employers and employees to determine wages at the enterprise level. This would facilitate hiring as well as introduce skill and performance based wage setting.

- Improve worker skills by investing in education. Labor productivity in Indonesia has risen much less than real wages. A recent study by the Ministry of Manpower found that almost 55 percent of the workforce only has an elementary school education and less than 5 percent has post-secondary school education. The new government's commitment to reprioritize spending to improve the quality and efficiency of spending by redirecting it to health and education could be key to improving education levels and the skills of workers.

- Improve the social security system while limiting the burden on the budget. An important political rationale for the high severance payments in Indonesia is the lack of an effective social security system. Although there are regulations that require employers with 10 or more employees to provide insurance with employer-employee based contributions, currently these are not strictly enforced. The Social Security Bill aims to improve the safety net, and would provide the basis for scaling back statutory severance payments. When implementing this system, the government needs to avoid the creation of unfunded contingent liabilities and setting payroll taxes at levels that would discourage hiring. 
Table 1. Indonesia: Trends in Labor Market

(In millions, unless stated otherwise)

\begin{tabular}{|c|c|c|c|c|c|c|c|c|}
\hline & 1997 & 1998 & 1999 & 2000 & 2001 & 2002 & 2003 & $20041 /$ \\
\hline \multirow{2}{*}{$\begin{array}{l}\text { Working age popoulation 2/ } \\
\text { (growth, in percent) }\end{array}$} & \multirow[t]{2}{*}{135.1} & 138.6 & 141.1 & 142.6 & 145.5 & 148.4 & 151.3 & 154.3 \\
\hline & & 2.6 & 1.8 & 1.1 & 2.0 & 2.0 & 2.0 & 2.0 \\
\hline Labor force $3 /$ & \multirow[t]{2}{*}{89.6} & 92.7 & 94.8 & 95.7 & 98.8 & 100.8 & 102.8 & 104.0 \\
\hline (growth, in percent) & & 3.5 & 2.3 & 0.8 & 3.3 & 2.0 & 1.9 & 1.2 \\
\hline Labor force participation rate 4/ & 66.3 & 66.9 & 67.2 & 67.1 & 67.9 & 67.9 & 67.9 & 67.4 \\
\hline \multirow{2}{*}{$\begin{array}{l}\text { Employed persons } \\
\quad \text { (growth, in percent) }\end{array}$} & \multirow[t]{2}{*}{85.4} & 87.7 & 88.8 & 89.8 & 90.8 & 90.6 & 90.8 & 93.7 \\
\hline & & 2.7 & 1.3 & 1.1 & 1.1 & -0.2 & 0.2 & 3.2 \\
\hline \multicolumn{9}{|l|}{ Share of employed persons (in percent) } \\
\hline Urban & $\ldots$ & $\ldots$ & $\ldots$ & 59.6 & 60.1 & 60.4 & 60.9 & $\ldots$ \\
\hline Rural & $\ldots$ & $\ldots$ & $\ldots$ & 40.4 & 39.9 & 39.6 & 39.1 & $\ldots$ \\
\hline Male & $\ldots$ & $\ldots$ & $\ldots$ & 67.1 & 68.6 & 69.5 & 71.3 & $\ldots$ \\
\hline Female & $\ldots$ & $\ldots$ & $\ldots$ & 32.9 & 31.4 & 30.5 & 28.7 & $\ldots$ \\
\hline Unemployed & 4.3 & 5.1 & 6.0 & 5.8 & 8.0 & 9.1 & 9.9 & 10.3 \\
\hline Unemployment rate (in percent) & 4.8 & 5.5 & 6.4 & 6.1 & 8.1 & 9.1 & 9.7 & 9.9 \\
\hline Formal sector (share of total, in perce & 31.7 & 30.3 & 31.9 & 31.5 & 33.0 & 32.4 & 31.1 & $\ldots$ \\
\hline Informal sector (share of total, in perc & 53.6 & 57.3 & 56.9 & 58.3 & 57.8 & 59.3 & 59.7 & $\ldots$ \\
\hline \multicolumn{9}{|l|}{ Memorandum Item } \\
\hline Real GDP growth (in percent) & 4.7 & -13.1 & 0.8 & 5.4 & 3.8 & 4.4 & 4.9 & 5.1 \\
\hline
\end{tabular}

Sources: Indonesian authorities; National Labor Force Survey; USAID; and Fund staff estimates.

1/ Data for 2004 are preliminary.

2/ Defined as population above 15 years of age.

3 / Includes those who work and those actively looking for a job; from 2001 includes transitionally unemployed and discouraged workers.

4/ Defined as the number of people in the labor force as a percentage of working age population. 
Table 2. Indonesia: Sectoral Employment Trends

\begin{tabular}{|c|c|c|c|c|c|c|c|c|}
\hline & 1997 & 1998 & 1999 & 2000 & 2001 & 2002 & 2003 & 2004 \\
\hline & \multicolumn{8}{|c|}{ (In millions, unless stated otherwise) } \\
\hline Agriculture, Forestry, Hunting and Fishery & 34.8 & 39.4 & 38.4 & 40.7 & 39.7 & 40.6 & 43.0 & 40.6 \\
\hline Mining and Quarrying & 0.9 & 0.7 & 0.7 & 0.8 & 1.0 & 0.6 & 0.7 & 1.0 \\
\hline Manufacturing Industry & 11.0 & 9.9 & 11.5 & 11.6 & 12.1 & 12.1 & 11.5 & 11.1 \\
\hline Electricity, Gas, and Water & 0.2 & 0.1 & 0.2 & 0.1 & 0.1 & 0.2 & 0.2 & 0.2 \\
\hline Construction & 4.2 & 3.5 & 3.4 & 3.5 & 3.8 & 4.3 & 4.1 & 4.5 \\
\hline Wholesale Trade, Retail Trade, Restaurants and Hotel & 17.0 & 16.8 & 17.5 & 18.5 & 17.5 & 17.8 & 17.2 & 19.1 \\
\hline Transportation, Storage, and Communications & 4.1 & 4.2 & 4.2 & 4.6 & 4.4 & 4.7 & 5.0 & 5.5 \\
\hline Financing, Insurance, Real Estate and Business Servic & 0.7 & 0.6 & 0.6 & 0.9 & 1.1 & 1.0 & 1.3 & 1.1 \\
\hline Community, Social, and Personal Services & 12.6 & 12.4 & 12.2 & 9.6 & 11.0 & 10.4 & 9.8 & 10.5 \\
\hline Others & 4.2 & 5.1 & 6.0 & 5.4 & 8.0 & 9.2 & 9.9 & 10.3 \\
\hline \multirow[t]{2}{*}{ Total } & 89.6 & 92.7 & 94.8 & 95.7 & 98.8 & 100.8 & 102.8 & 104.0 \\
\hline & \multicolumn{7}{|c|}{ (In percent of those employed) } & \\
\hline Agriculture, Forestry, Hunting and Fishery & 38.8 & 42.5 & 40.5 & 42.5 & 40.2 & 40.3 & 41.9 & 39.1 \\
\hline Mining and Quarrying & 1.0 & 0.7 & 0.8 & 0.8 & 1.0 & 0.6 & 0.7 & 1.0 \\
\hline Manufacturing Industry & 12.3 & 10.7 & 12.1 & 12.2 & 12.2 & 12.0 & 11.2 & 10.6 \\
\hline Electricity, Gas, and Water & 0.3 & 0.2 & 0.2 & 0.1 & 0.1 & 0.2 & 0.2 & 0.2 \\
\hline Construction & 4.7 & 3.8 & 3.6 & 3.7 & 3.9 & 4.2 & 4.0 & 4.4 \\
\hline Wholesale Trade, Retail Trade, Restaurants and Hotel & 18.9 & 18.1 & 18.5 & 19.3 & 17.7 & 17.7 & 16.8 & 18.4 \\
\hline Transportation, Storage, and Communications & 4.6 & 4.5 & 4.4 & 4.8 & 4.5 & 4.6 & 4.8 & 5.3 \\
\hline Financing, Insurance, Real Estate and Business Servic & 0.7 & 0.7 & 0.7 & 0.9 & 1.1 & 1.0 & 1.3 & 1.1 \\
\hline Community, Social, and Personal Services & 14.0 & 13.4 & 12.9 & 10.0 & 11.1 & 10.3 & 9.6 & 10.1 \\
\hline Others & 4.7 & 5.5 & 6.4 & 5.7 & 8.1 & 9.1 & 9.6 & 9.9 \\
\hline Total & 100.0 & 100.0 & 100.0 & 100.0 & 100.0 & 100.0 & 100.0 & 100.0 \\
\hline
\end{tabular}

Source: National Labor Force Survey. 
Table 3: Indicators of Labor Market Rigidities - A Regional Perspective 1/

$$
\begin{aligned}
& \text { Indonesia Malaysia Thailand Korea Regional United } \\
& \text { Average States }
\end{aligned}
$$

\begin{tabular}{lcccccc} 
Difficulty of hiring index & 61 & 0 & 67 & 11 & 21 & 0 \\
$\begin{array}{l}\text { Difficulty of firing index } \\
\text { Rigidity of hours index }\end{array}$ & 70 & 10 & 20 & 30 & 23 & 10 \\
Rigidity of employment index 2 & 57 & 3 & 42 & 34 & 24 & 3 \\
Firing costs (weeks of wages) & 157 & 74 & 47 & 90 & 53 & 8 \\
Memorandun item & & & & & & \\
GNI per capita (US\$) & 810 & 3,780 & 2,190 & 12,020 & 4,156 & 37,610 \\
\hline
\end{tabular}

Source: Doing Business, The World Bank.

$1 /$ The index varies from $0-100$, with higher values representing more rigid regulations.

$2 /$ This index is an average of the three indices shown above, that is, indices for difficulty of hiring and firing and for rigidity of work hours. 
Table 4. Labor Regulations and Worker Benefits in Selected Countries

\begin{tabular}{|c|c|c|c|c|}
\hline & Indonesia & Malaysia & Korea & $\begin{array}{l}\text { United } \\
\text { States }\end{array}$ \\
\hline \multicolumn{5}{|l|}{ I. Minimum Wages: } \\
\hline 1. Established by Law & Yes & No & Yes & Yes \\
\hline 2. Modalities of setting the MW & $\begin{array}{l}\text { Based on minimum physical } \\
\text { needs (KFM) and cost of living. }\end{array}$ & Not applicable & $\begin{array}{l}\text { Based on cost-of-living, } \\
\text { productivity and similar } \\
\text { prevailing wages. }\end{array}$ & $\begin{array}{l}\text { Based on cost- } \\
\text { of living } \\
\text { adjustments. }\end{array}$ \\
\hline 3. Current minimum wage & Rp 714,000 (US\$75) per month & Not applicable. & $\ldots$ & $\begin{array}{l}\text { US\$5.15 per } \\
\text { hours. }\end{array}$ \\
\hline $\begin{array}{l}\text { II. Severance pay (for company } \\
\text { downsizing or closure) }\end{array}$ & Yes & Yes & Yes & $\begin{array}{l}\text { Up to } \\
\text { individual } \\
\text { companies. }\end{array}$ \\
\hline 1. Mandated by Law & Yes & Yes & Yes & $\ldots$ \\
\hline \multicolumn{5}{|l|}{$\begin{array}{l}\text { 2. Amount (in months of salary) for } \\
\text { severance pay }\end{array}$} \\
\hline $\begin{array}{l}\text { A. For workers with } 4 \text { years of } \\
\text { service }\end{array}$ & 12 & 2.4 & 2 & $\cdots$ \\
\hline B. For workers with 20 years & 25 & 16 & 6 & $\ldots$ \\
\hline \multicolumn{5}{|l|}{ III. Social security benefits } \\
\hline A. Unemployment insurance & No & No & Yes & Yes \\
\hline $\begin{array}{l}\text { B. All employers mandated to } \\
\text { have pension system for their } \\
\text { workers funded by } \\
\text { employee/employer } \\
\text { contribution }\end{array}$ & $\begin{array}{l}\text { Employers with more than } 10 \\
\text { employees are expected to have } \\
\text { pension system; not enforced. }\end{array}$ & Yes & Yes & Yes \\
\hline $\begin{array}{l}\text { C. Compensation for old age, } \\
\text { disability, and death }\end{array}$ & $\begin{array}{l}\text { Provident Fund system (lump- } \\
\text { sum, periodical and partial lump- } \\
\text { sum benefits). New Social } \\
\text { Security Law passed in October } \\
2004 \text { would imply } \\
\text { extension of coverage but } \\
\text { specifics not available yet and to } \\
\text { be defined in implementing } \\
\text { regulations. }\end{array}$ & Provident Fund system. & Social Insurance System & $\begin{array}{l}\text { Social Security } \\
\text { System. }\end{array}$ \\
\hline
\end{tabular}




\section{References}

Athukorala Prema-Chandra and Bambang Sentosa (1997), "Gains from Indonesian Export Growth: Do Linkages Matter," Bulletin of Indonesian Economic Studies, Vol. 33 (2).

Brooks, Ray and Ran Tao (2003), "China's Labor Market Performance and Challenges," IMF Working Paper, WP/03/210 (November).

Jacobson, Tor, A. Vredin and A. Warne (1997), "Common Trends and Hysteresis in Scandinavian Unemployment," European Economic Review, Vol. 41, Issue 9.

Lipsey, Robert and Fredrik Sjoholm (2004), "Foreign Direct Investment, Education and Wages in Indonesian Manufacturing," Journal of Development Economics, Vol. 73.

Roy, Sudipta Dutta (2004), “Employment Dynamics in Indian Industry: Adjustment Lags and the Impact of Job Security Regulations, Journal of Development Economics, Vol. 73.

Suryahadi, A., P. Chen and R. Tylers (2001), “Openness, Technological Change and Labor Demand in Pre-Crisis Indonesia," Asian Economic Journal, Vol.15 (3).

Suryahadi, Asep, Widyanti, Wenefrida, Perwira, Daniel and Sumarto, Sudarno (2003), "Minimum Wage Policy and its Impact on Employment in the Urban Formal Sector. Bulletin of Indonesian Economic Studies, Vol. 39, No.1 (April), pp.29-50.

Thomas, Duncan, Kathleen Begle, Elizabeth Frankenberg, Bondan Sikoki, John Strauss, Graciela Teruel (2004), "Education in a Crisis", Journal of Development Economics," Vol. 74.

Takii, Sadayuki (2005), "Productivity Spillovers and Characteristics of Foreign Multinational Plants in Indonesian Manufacturing," Journal of Development Economics, Vol. 76.

Turner, Anthony G. and Stephen S. Golub (1997), "Towards a System of Multilateral Unit Labor Cost-Based Competitiveness Indicators for Advanced, Developing, and Transition Economics," IMF Working Paper, WP/97/151 (November).

Jurajda, Štěpán and Katarina Mathernová (2004), "How to Overhaul the Labor Market: Political Economy of Recent Czech and Slovak Reforms", background paper prepared for the World Development Report (March).

Heckman, James and Carmen Pagés (2003)“, Law and Employment Lessons from Latin American and the Caribbean, NBER Working Paper Series, Working Paper 10129, National Bureau of Economic Research (December).

USAID/GOI (2004), “Indonesia's Employment Protection Legislation: Swimming Against the Tide?" Report prepared by GIAT. 